Prepared in cooperation with the City of Salem, Oregon

\title{
Modeling Hydrodynamics, Water Temperature, and Suspended Sediment in Detroit Lake, Oregon
}

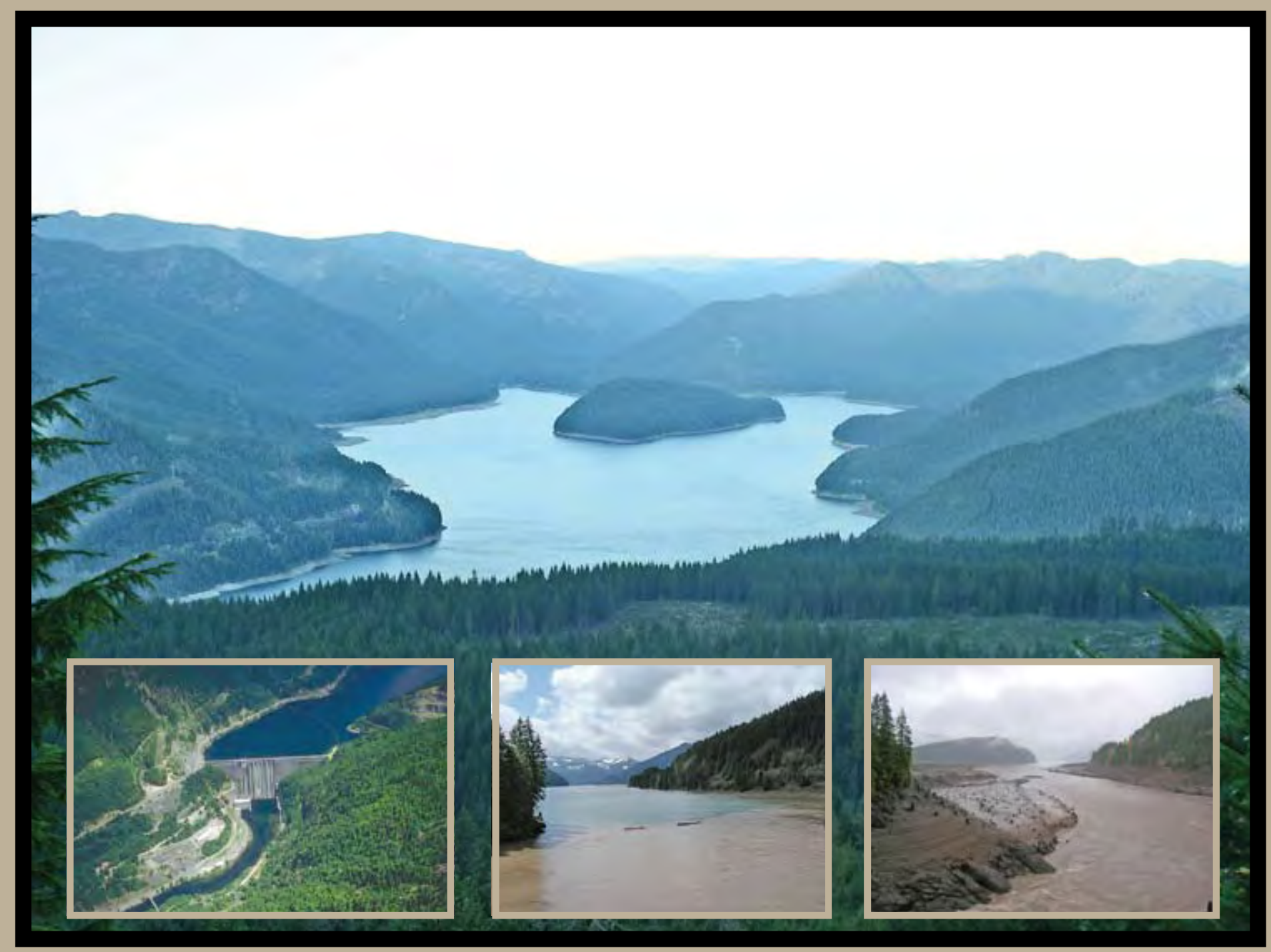

Scientific Investigations Report 2007-5008

U.S. Department of the Interior U.S. Geological Survey 
Front Cover:

Photograph of Detroit Lake and Piety Island, looking east. (Photograph by Mark Uhrich, U.S. Geological Survey, September 29, 2004.)

Insets from left to right:

Inset 1: Photograph showing aerial view of Detroit Dam, taken from just west of the dam. (Photograph from U.S. Army Corps of Engineers, July 11, 1990.)

Inset 2: Photograph showing Breitenbush River storm inflow to Detroit Lake, looking west. (Photograph by Heather Bragg, U.S. Geological Survey, April 14, 2002.)

Inset 3: Photograph showing Breitenbush River inflow to Detroit Lake, looking west. (Photograph by Heather Bragg, U.S. Geological Survey, November 7, 2006.)

Back Cover: View of Mt. Jefferson over Detroit Lake, looking east. (Photograph by David Piatt, U.S. Geological Survey, July 4, 2004.) 


\section{Modeling Hydrodynamics, Water Temperature, and Suspended Sediment in Detroit Lake, Oregon}

By Annett B. Sullivan, Stewart A. Rounds, Steven Sobieszczyk, and Heather M. Bragg

Prepared in cooperation with the City of Salem, Oregon

Scientific Investigations Report 2007-5008 


\title{
U.S. Department of the Interior DIRK KEMPTHORNE, Secretary
}

\author{
U.S. Geological Survey \\ Mark D. Myers, Director
}

\section{U.S. Geological Survey, Reston, Virginia: 2007}

For product and ordering information:

World Wide Web: http://www.usgs.gov/pubprod

Telephone: 1-888-ASK-USGS

For more information on the USGS--the Federal source for science about the Earth, its natural and living resources, natural hazards, and the environment:

World Wide Web: http://www.usgs.gov

Telephone: 1-888-ASK-USGS

Any use of trade, product, or firm names is for descriptive purposes only and does not imply endorsement by the U.S. Government.

Although this report is in the public domain, permission must be secured from the individual copyright owners to reproduce any copyrighted materials contained within this report.

Suggested citation:

Sullivan, A.B., Rounds, S.A., Sobieszczyk, S., and Bragg, H.M., 2007, Modeling hydrodynamics, water temperature, and suspended sediment in Detroit Lake, Oregon: U.S. Geological Survey Scientific Investigations Report 2007-5008, $40 \mathrm{p}$. 


\section{Contents}

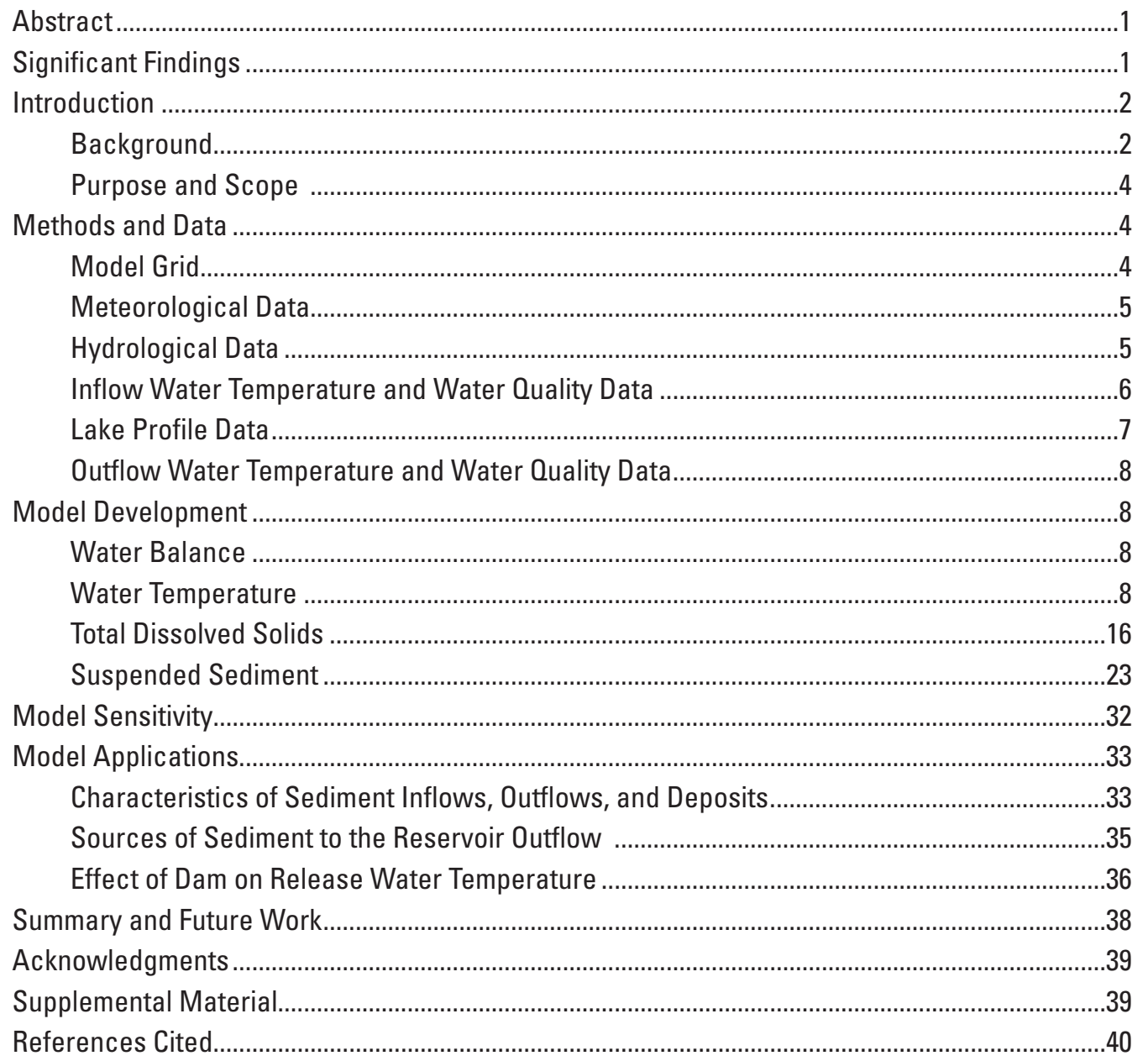




\section{Figures}

Figure 1. Map showing locations of water-quality monitors and lake sampling sites in the Detroit Lake drainage area, Oregon

Figure 2. Map showing location of segment boundaries for the Detroit Lake model grid $\ldots \quad 5$

Figure 3. Graph showing volume-elevation curves for Detroit Lake, Oregon, from the U.S. Army Corps of Engineers (USACE) and as represented by the model grid

Figure 4. Graph showing measured and modeled forebay water-surface elevations, Detroit Lake, Oregon, calendar years 2002 and 2003, and the period between December 1, 2005, and February 1, 2006

Figure 5. Graph showing modeled water temperature profiles in Detroit Lake, Oregon, near the dam as a function of time during 2003

Figure 6. Measured water temperature profiles at three locations in Detroit Lake, Oregon, compared to modeled water temperature at the same location and time in 2002

Figure 7. Measured water temperatures profiles at three locations in Detroit Lake, Oregon, compared to modeled water temperature at the same location and time in 2003

Figure 8. Measured water temperature profiles at four locations in Detroit Lake, Oregon, compared to modeled water temperature at the same location and time in 2006

Figure 9. Graphs showing measured water temperatures from a string of thermistors suspended from the log boom in Detroit Lake, Oregon, compared to modeled water temperature at the same depth and time in 2003

Figure 10. Graph showing modeled water temperatures in the Detroit Lake, Oregon, reservoir outflow compared to measured water temperature in the North Santiam River at Niagara, $6 \mathrm{~km}$ downstream of the reservoir outflow in 2003

Figure 11. Modeled total dissolved solids profiles in Detroit Lake, Oregon, near the dam as a function of time during 2003

Figure 12. Measured specific conductance profiles at three locations in Detroit Lake, Oregon, compared to modeled specific conductance (derived from total dissolved solids) at the same location and time in 2002

Figure 13. Measured specific conductance profiles at three locations in Detroit Lake, Oregon, compared to modeled specific conductance (derived from total dissolved solids) at the same location and time in 2003

Figure 14. Measured specific conductance profiles at four locations in Detroit Lake, Oregon, compared to modeled specific conductance (derived from total dissolved solids) at the same location and time in 2006

Figure 15. Graph showing modeled specific conductance (converted from modeled total dissolved solids) in the Detroit Lake, Oregon, reservoir outflow compared to measured specific conductance in the North Santiam River at Niagara, $6 \mathrm{~km}$ downstream, in 2003 


\section{Figures-continued}

Figure 16. Modeled profiles of suspended sediment concentrations in Detroit Lake, Oregon, near the dam as a function of time during 2003

Figure 17. Total suspended sediment concentration profiles, both measured and calculated from turbidity, at three locations in Detroit Lake, Oregon, compared to modeled total suspended sediment concentration at the same location and time in 2002

Figure 18. Total suspended sediment concentration profiles, both measured and calculated from turbidity, at three locations in Detroit Lake, Oregon, compared to modeled total suspended sediment concentration at the same location and time in 2003

Figure 19. Total suspended sediment concentration profiles, both measured and calculated from turbidity, at four locations in Detroit Lake, Oregon, compared to modeled total suspended sediment concentration at the same location and time in 2006

Figure 20. Profiles showing chemical ( $\mathrm{pH}$ and dissolved oxygen) and physical (surface turbidity) evidence of an algal bloom at the Blowout lake monitoring site, Detroit Lake, Oregon, June 12, 2002

Figure 21. Graphs showing modeled total suspended sediment concentration in reservoir outflow, converted to turbidity and modeled distribution of two sediment size groups, Detroit Lake, Oregon, 2003

Figure 22. Maps showing modeled spatial distribution of suspended sediment deposition in Detroit Lake, Oregon, for calendar years 2002, 2003, and the period between December 1, 2005 and February 1, 2006

Figure 23. Graphs showing modeled sources of total sediment in reservoir outflow of Detroit Lake during 2003

Figure 24. Graphs showing $(A)$ Maximum water temperature standard for the North Santiam River, Oregon, downstream of Big Cliff and Detroit Dams, an estimate of the water temperatures in the absence of the dams calculated using a volume-weighted mix of reservoir inflows for 2003, and modeled water temperatures of the water released from Detroit Dam and $(B)$ smoothed water temperature of the volume-weighted mix of the reservoir inflows, used as a temperature target for the selective withdrawal simulation, along with the modeled reservoir release temperatures for that scenario

Figure 25. Modeled water temperature profiles in Detroit Lake, Oregon, near the dam as a function of time during 2003 for calibrated conditions, and the selective withdrawal scenario 


\section{Tables}

Table 1. Regression equations for estimating total and clay-size suspended sediment concentrations from turbidity data for the major tributaries to Detroit Lake,

Oregon

Table 2. Model parameters and values used in the Detroit Lake, Oregon, model

Table 3. Detroit Lake model Goodness-of-fit statistics, calendar years 2002 and 2003 and a storm event in January 2006

Table 4. Results from sensitivity testing showing the effect of changing a particular input parameter on annual average temperature, suspended sand and silt, and suspended clay in the whole lake and in the lake outflow for 2003

Table 5. Modeled sand and silt, clay, and total sediment entering, exiting, and deposited in Detroit Lake for the three modeled time periods

Table 6. Fate of suspended sand and silt, and suspended clay from the major tributaries to Detroit Lake, Oregon, 2003

\section{Conversion Factors and Datums}

SI to Inch-Pound

\begin{tabular}{lcl}
\hline Multiply & By & To obtain \\
\hline centimeter $(\mathrm{cm})$ & 0.394 & inch (in.) \\
centimeter per second $(\mathrm{cm} / \mathrm{s})$ & 0.394 & inch per second $(\mathrm{in} / \mathrm{s})$ \\
centimeter per square second $\left(\mathrm{cm}^{2} \mathrm{~s}^{2}\right)$ & 0.394 & inch per square second $\left(\mathrm{in} / \mathrm{s}^{2}\right)$ \\
cubic meter $\left(\mathrm{m}^{3}\right)$ & 264.2 & gallon $($ gal $)$ \\
cubic meter $\left(\mathrm{m}^{3}\right)$ & 0.0008107 & acre-foot $($ acre-ft) \\
gram per cubic centimeter $\left(\mathrm{g} / \mathrm{cm}^{3}\right)$ & 62.4220 & pound per cubic foot $\left(\mathrm{lb} / \mathrm{ft}^{3}\right)$ \\
kilometer $(\mathrm{km})$ & 0.6214 & mile $(\mathrm{mi})$ \\
kilogram $(\mathrm{kg})$ & 2.205 & pound avoirdupois $(\mathrm{lb})$ \\
kilogram per square meter $\left(\mathrm{kg} / \mathrm{m}^{2}\right)$ & 0.2048 & pound per square foot $\left(\mathrm{lb} / \mathrm{ft}^{2}\right)$ \\
meter $(\mathrm{m})$ & 3.281 & foot $(\mathrm{ft})$ \\
meter per day $(\mathrm{m} / \mathrm{d})$ & 3.281 & foot per day $(\mathrm{ft} / \mathrm{d})$ \\
metric ton & 1.102 & ton \\
square meter per gram $\left(\mathrm{m}^{2} / \mathrm{g}\right)$ & 4882 & square foot per pount $\left(\mathrm{ft}^{2} / \mathrm{lb}\right)$ \\
square meter per second $\left(\mathrm{m}^{2} / \mathrm{s}\right)$ & 10.76 & square foot per second $\left(\mathrm{ft}^{2} / \mathrm{s}\right)$ \\
square kilometer $\left(\mathrm{km}^{2}\right)$ & 247.1 & acre \\
square centimeter $\left(\mathrm{cm}^{2}\right)$ & 0.001076 & square foot $\left(\mathrm{ft}^{2}\right)$ \\
square meter $\left(\mathrm{m}^{2}\right)$ & 10.76 & square foot $\left(\mathrm{ft}^{2}\right)$ \\
square centimeter $\left(\mathrm{cm}^{2}\right)$ & 0.1550 & square inch $\left(\mathrm{ft}^{2}\right)$ \\
square kilometer $\left(\mathrm{km}^{2}\right)$ & 0.3861 & square mile $\left(\mathrm{mi} i^{2}\right)$ \\
Watt per square meter per second & 0.317 & BTU per square foot per second \\
{$\left[\left(\mathrm{W} / \mathrm{m}^{2}\right) / \mathrm{s}\right]$} & & {$\left[\left(B T U / \mathrm{ft}^{2}\right) / \mathrm{s}\right]$} \\
\hline
\end{tabular}




\section{Conversion Factors and Datums—continued}

Temperature in degrees Celsius $\left({ }^{\circ} \mathrm{C}\right)$ may be converted to degrees Fahrenheit $\left({ }^{\circ} \mathrm{F}\right)$ as follows:

$$
{ }^{\circ} \mathrm{F}=\left(1.8 x^{\circ} \mathrm{C}\right)+32
$$

Specific conductance is given in microsiemens per centimeter at 25 degrees Celsius $(\mu \mathrm{S} / \mathrm{cm}$ at $\left.25^{\circ} \mathrm{C}\right)$.

Concentrations of chemical constituents in water generally are given in milligrams per liter $(\mathrm{mg} / \mathrm{L})$, which is approximately equal to parts per million.

Turbidity is given in Formazin Nephelometric Units, or FNUs.

Datum

Horizontal coordinate information is referenced to North American Datum of 1927 (NAD27).

Vertical coordinate information is referenced to the National Geodetic Vertical Datum of 1929 (NGVD29). 
This page intentionally left blank. 


\title{
Modeling Hydrodynamics, Water Temperature, and Suspended Sediment in Detroit Lake, Oregon
}

\author{
By Annett B. Sullivan, Stewart A. Rounds, Steven Sobieszczyk, and Heather M. Bragg
}

\section{Abstract}

Detroit Lake is a large reservoir on the North Santiam River in west-central Oregon. Water temperature and suspended sediment are issues of concern in the river downstream of the reservoir. A CE-QUAL-W2 model was constructed to simulate hydrodynamics, water temperature, total dissolved solids, and suspended sediment in Detroit Lake. The model was calibrated for calendar years 2002 and 2003, and for a period of storm runoff from December 1, 2005, to February 1, 2006. Input data included lake bathymetry, meteorology, reservoir outflows, and tributary inflows, water temperatures, total dissolved solids, and suspended sediment concentrations. Two suspended sediment size groups were modeled: one for suspended sand and silt with particle diameters larger than 2 micrometers, and another for suspended clay with particle diameters less than or equal to 2 micrometers. The model was calibrated using lake stage data, lake profile data, and data from a continuous water-quality monitor on the North Santiam River near Niagara, about 6 kilometers downstream of Detroit Dam. The calibrated model was used to estimate sediment deposition in the reservoir, examine the sources of suspended sediment exiting the reservoir, and examine the effect of the reservoir on downstream water temperatures.

\section{Significant Findings}

1. An annual pattern of water temperature exists in Detroit Lake that was similar in all modeled time periods. The reservoir typically is isothermal and cold at the beginning of the year. In spring, the lake surface warms and a thermocline develops by summer, isolating cold, dense water at the reservoir bottom. In autumn, the water surface cools, and eventually the reservoir mixes, or "turns over," and becomes isothermal again.
2. Detroit Lake has an important influence on downstream water temperature in the North Santiam River. Reservoir outflow water temperature reaches an annual maximum in autumn, at times exceeding the water temperature criterion. In the absence of Detroit Dam, the annual water temperature maximum would occur in midsummer. Water released from Detroit Lake also has less daily temperature variation compared to what would occur in the absence of the lake.

3. Model results demonstrated that if a selective withdrawal device were installed at Detroit Dam, water temperatures of the outflow from Detroit Lake could remain less than Oregon's maximum water temperature criteria for the North Santiam River all year. A more natural seasonal temperature pattern could be produced through most of the year, but in autumn, the lake did not have enough stored cold water to match this hypothetical seasonal temperature pattern downstream of the dam.

4. Total dissolved solids (TDS) had an annual cycle in Detroit Lake. During spring storms, the inflowing TDS concentrations were relatively low. As the lake was not yet strongly stratified, these inflows acted to decrease TDS throughout the lake. As summer progressed, TDS concentrations in the inflows typically increased. The summer temperature stratification acted to keep summer inflows, with their higher TDS concentrations, in the epilimnion, preventing these inflows from mixing into the colder, denser hypolimnion. With the breakdown of stratification in autumn, waters with higher TDS concentrations in the epilimnion were mixed throughout the lake.

5. The largest suspended sediment loads entered Detroit Lake during storm events. During the record-breaking precipitation between December 1, 2005, and February 1, 2006 , more mass of suspended sediment entered and was deposited in the reservoir than in the entire calendar years of 2002 and 2003 combined. In summer, when storms were few, the inflow of suspended sediment into the lake was small, and resultant lake concentrations also were low. 
6. Most of the mass of sediment entering Detroit Lake was in a size class designated "sand and silt." Sediment in that size class comprised 85 percent of the inflowing mass in calendar year 2002, 83 percent in calendar year 2003, and 92 percent during the modeled 2005-06 storms.

7. Although the sand and silt component made up most of the mass of suspended sediment entering the reservoir, it comprised only a small portion of the suspended sediment exiting the reservoir. It constituted only 9 percent of the outflowing sediment mass in calendar year 2002, 7 percent in 2003, and 16 percent during the modeled 2005-06 storms. Most of the mass of sediment leaving Detroit Lake was composed of clay-sized particles.

8. Assuming a bulk density of $1.89 \mathrm{~g} / \mathrm{cm}^{3}, 14,300 \mathrm{~m}^{3}$ (11.6 acre-ft) of sediment was deposited in Detroit Lake in $2002,11,820 \mathrm{~m}^{3}$ (9.6 acre-ft) in 2003 and 34,900 $\mathrm{m}^{3}$ (28.3 acre-ft) in storms from December 1, 2005, to February 1, 2006. Each of these sediment volumes is less than 0.01 percent of Detroit Lake's full pool volume of 561 million $\mathrm{m}^{3}(455,000$ acre-ft). The model results indicate that most sediment deposition occurred in the upper reaches of the reservoir, near the inflows of Breitenbush and North Santiam Rivers.

9. All inflows contributed suspended sediment to the reservoir outflow. The North Santiam River was the largest contributor, followed by Breitenbush River, in calendar year 2003. The North Santiam River was unique in that it contributed sediment to the outflow in October and November, when contributions from other tributaries decreased. Tributaries that entered Detroit Lake closer to the dam were more likely to contribute suspended sediment that was exported to the North Santiam River downstream of the dam.

\section{Introduction}

\section{Background}

The U.S. Army Corps of Engineers (USACE) constructed and operates a system of 13 dams and reservoirs in Oregon's Willamette Basin; Detroit Lake is one of the larger of these reservoirs on the western slope of the Cascade Range. The lake is situated on the North Santiam River (fig. 1) behind Detroit Dam, a 141-m high concrete structure finished in 1953. The watershed encompasses $1,130 \mathrm{~km}^{2}$, and at a fullpool water-surface elevation of $478.2 \mathrm{~m}, 561$ million $\mathrm{m}^{3}$ $(455,000$ acre- $\mathrm{ft})$ of water is stored in the reservoir, with a surface area of $14.5 \mathrm{~km}^{2}$. The water-surface elevation varies substantially, by $35 \mathrm{~m}$ or more, over the course of a year. It is kept high in summer for recreation, and drawn down in winter for flood control. Detroit Lake also is used for power generation, irrigation, and improvement of downstream navigation.

A smaller, reregulating dam, Big Cliff, lies $5 \mathrm{~km}$ downstream of Detroit Dam. It is designed to dampen the flow variations caused by Detroit Dam's power generating operations. There are an additional $36 \mathrm{~km}^{2}$ of watershed area between Detroit and Big Cliff Dams. At a full-pool watersurface elevation of $367.7 \mathrm{~m}$, Big Cliff Reservoir holds 8 million $\mathrm{m}^{3}$ (6,450 acre-ft of water), with a surface area of $0.6 \mathrm{~km}^{2}$.

Major inflows to Detroit Lake include the North Santiam and Breitenbush Rivers, and French, Blowout, Box Canyon, and Kinney Creeks. The watershed reaches its highest point at Mount Jefferson at 3,204 $\mathrm{m}$. The climate of this area is a temperate one, characterized by dry summers and wet winters. Mean annual precipitation for 1971-2000 was $228 \mathrm{~cm}$, and most fell between November and April (Taylor, 2002). For the same period, the average annual air temperature at Detroit Dam was $10.6{ }^{\circ} \mathrm{C}$. The coldest month was January, with an average temperature of $3.7^{\circ} \mathrm{C}$, and the warmest month was August, with an average temperature of $18.8^{\circ} \mathrm{C}$. The watershed geology is dominated by volcanic andesites and basalts with some alluvial and glacial deposits (Uhrich and Bragg, 2003). Steep slopes and weathered, clay-rich soils lead to landslides and earthflows that deliver sediment into many of the creeks and rivers of the upper basin. The land is mostly forested, and timber harvesting and recreation are the largest land uses. More than 95 percent of the land in the watershed upstream of Detroit Dam is part of the Willamette National Forest, with the rest divided between the Mount Hood National Forest, private owners, the Oregon Department of Forestry (ODF), the Warm Springs Indian Reservation, and the Bureau of Land Management.

Downstream of Detroit and Big Cliff Dams, the North Santiam River flows $75 \mathrm{~km}$ to the Santiam River, which flows $20 \mathrm{~km}$ to the Willamette River between the cities of Albany and Salem. The North Santiam River is governed by Oregon's "Three Basin Rule" (Oregon Department of Environmental Quality, 2003), designed to protect the river's water quality, particularly as a source of clean drinking water. The rule has been successful at limiting new point source discharges into the river. Water temperature and suspended sediment, however, remain issues of concern.

Portions of the North Santiam and Santiam Rivers downstream of Detroit Lake exceed Oregon's maximum water temperature criteria at times, and these reaches were included on Oregon's most recent 303(d) list of impaired waterbodies (Oregon Department of Environmental Quality, 2006). To address this issue, a water temperature TMDL (Total Maximum Daily Load) was developed for these and other rivers in the Willamette Basin; the TMDL was signed by Oregon's Department of Environmental Quality on September 21, 2006. As part of that work, a hydrodynamic 


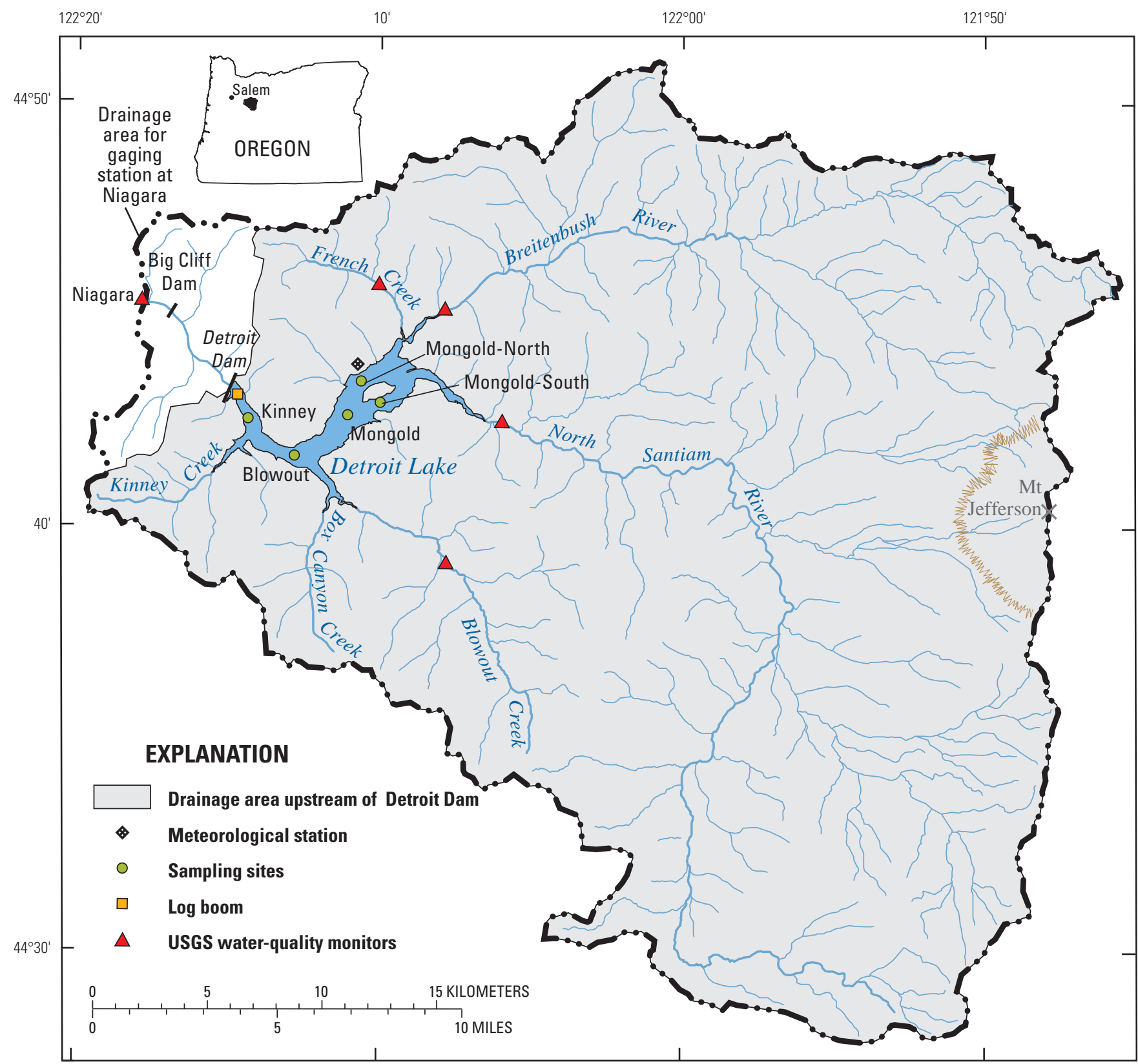

Base map modified from U.S. Geological Survey digital data $(1: 24,000)$. Projection: UTM, Zone 10, North American Datum of 1927.

Figure 1. Locations of water-quality monitors and lake sampling sites in the Detroit Lake drainage area, Oregon.

and water temperature model was developed, and simulations were run, to examine the effects of riparian shading, weather conditions, point sources, and Detroit Dam release flows and temperatures on North Santiam River water temperatures (Sullivan and Rounds, 2004). That study showed that water temperatures in these rivers were indeed sensitive to the temperatures and flows released from Detroit Dam, as well as some of the other factors. Although State temperature criteria focus on problems related to water that is too warm, temperatures also can be too cool for fish at times. Populations of spring Chinook salmon (Oncorhynchus tshawytscha) are declining in the North Santiam River, and dam outflow temperatures that are too cool in midsummer may be a contributing factor (E\&S Environmental Chemistry, Inc. and North Santiam Watershed Council, 2002). The outflow of Detroit Lake in June generally is $5-7^{\circ} \mathrm{C}$, cooler than the ideal of $10-13^{\circ} \mathrm{C}$ for migrating adult Chinook (Larson, 2000). 
Suspended sediment concentrations in the North Santiam River also can be of concern. The City of Salem takes its primary supply of drinking water from the North Santiam River approximately $45 \mathrm{~km}$ downstream of Detroit Lake. In the past, during some large storms and periods of sustained high levels of turbidity in the lake, high concentrations of suspended sediment in the North Santiam River have required the city to shut off its water intake and, later, to construct a chemical pretreatment system. The U.S. Geological Survey (USGS) has worked in partnership with the City of Salem since 1998 to monitor and study sediment and turbidity throughout the North Santiam River watershed (Uhrich and Bragg, 2003; Bragg and Uhrich, 2004).

\section{Purpose and Scope}

Developing a model that simulates the transport and fate of suspended sediment and the dynamics of water temperature in Detroit Lake is an important component of understanding how the lake affects suspended sediment and temperature in the North Santiam and Santiam Rivers downstream of Detroit Lake. The objectives of this study were to (1) develop a model of Detroit Lake to simulate circulation, water temperature, TDS, and suspended sediment in the reservoir and the reservoir's outflow, (2) understand processes affecting suspended sediment and quantify sediment sources and transport to the lake outlet as well as deposition in the lake, and (3) understand processes controlling water temperature in the lake and lake outflow, and demonstrate the water temperature effects of a hypothetical selective withdrawal device.

The Detroit Lake model, described in this report, was developed for the entire calendar years of 2002 and 2003 and also for the period December 1, 2005, through February 1, 2006 (the "2005-06 storms") in order to simulate some large winter storm events. During January 2006, about $70 \mathrm{~cm}$ (27.6 in.) of precipitation were recorded at Detroit Dam, making it the wettest January ever recorded, breaking the previous record set in 1970 (Oregon Climate Service, 2006). Processes occurring in Big Cliff Reservoir, the reregulating reservoir downstream of Detroit Lake, were not included in this model. The monitoring station on the North Santiam River at Niagara is downstream of Big Cliff Dam, and outflows from Detroit Lake could be influenced by processes in the $6 \mathrm{~km}$ reach between the outflow and Niagara, including heat exchange across the air-water interface, and tributary inflows.

This investigation resulted from a scientific and financial partnership between the USGS and the City of Salem, Oregon. Funding for the installation of a meteorological station near Detroit Lake was provided by USACE.

\section{Methods and Data}

The Detroit Lake model was constructed with CE-QUALW2, a two-dimensional, laterally-averaged, hydrodynamic and water quality model from the USACE (Cole and Wells, 2002). The same model was used in the Oregon Department of Environmental Quality's TMDL work for the Willamette River, including the Santiam and North Santiam subbasins. CE-QUAL-W2 is capable of simulating hydrodynamics, water temperature, and a number of other water quality constituents, including TDS, and multiple suspended sediment groups. A model grid based on the lake's bathymetry was developed. Other model inputs included meteorology, inflows and outflows, inflow water temperatures, TDS concentrations, and suspended sediment concentrations. The water balance was calibrated by comparing modeled and measured lake stage for all modeled time periods. The model was calibrated for water temperature, TDS, and suspended sediment through comparisons of model output to measured data. All data used to run the Detroit Lake model, as well as measured profile data, are available online (see section, "Supplemental Material").

Version 3.12 of CE-QUAL-W2 formed the basis of the Detroit Lake model. This version was modified by USGS project personnel to (1) fix coding errors either posted by CE-QUAL-W2's development team or found by USGS, (2) add new model output fluxes related to sediment deposition, and (3) enhance model capabilities through the addition of a new subroutine to automatically blend outflows from multiple reservoir outlets to match a user-supplied downstream temperature target. All coding changes were extensively tested to assure proper model performance prior to their use. The blending routines were documented and applied previously by Sullivan and Rounds (2006). CE-QUAL-W2 uses a variable time step to ensure the numerical stability of its computational methods; this time step averaged 52 seconds for the 2002 simulation, 49 seconds for 2003, and 23 seconds for 2005-06.

\section{Model Grid}

A geographic information system (GIS) dataset for Detroit Lake was created by combining a digital raster graphic of Detroit Lake with cross sections measured in the field by USGS personnel using acoustic Doppler techniques. Using GIS, the reservoir was divided into model segments (fig. 2). Ten equally spaced cross sections were subsampled from each segment using GIS techniques, then averaged to determine a representative cross section for each model segment. 


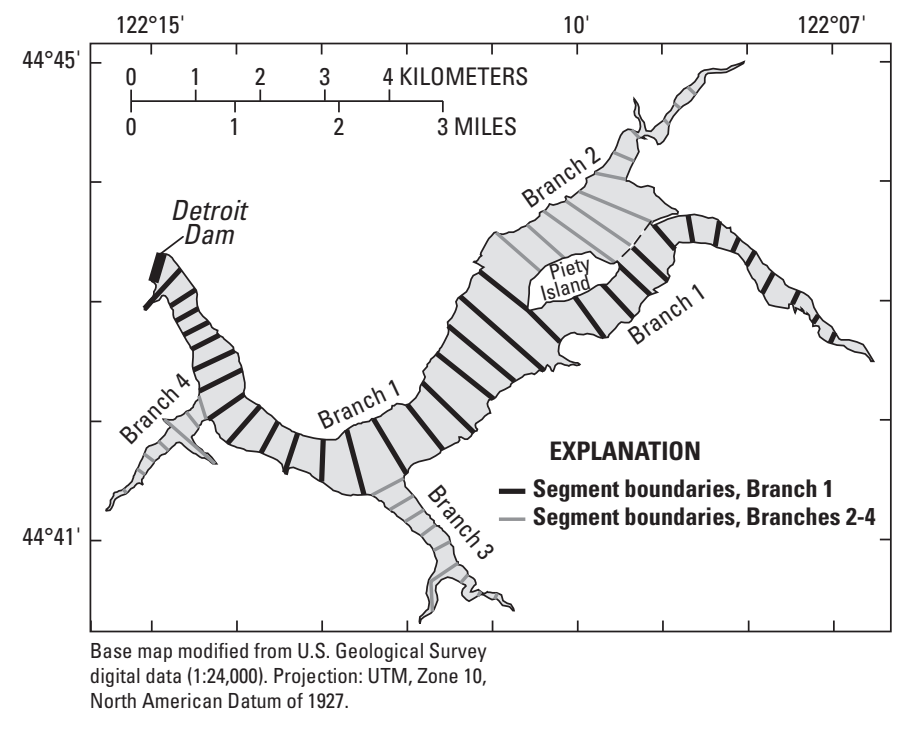

Figure 2. Location of segment boundaries for the Detroit Lake model grid. Branch 1, the main branch, extends from the North Santiam River inflow to the dam; the other branches join the main branch at the locations shown.

Segments in CE-QUAL-W2 are grouped together into branches, which connect to form the model grid. The Detroit Lake grid consists of four model branches: The first, or main, branch has 33 segments, extending from the North Santiam River inflow to Detroit Dam. The second branch consists of 11 segments, beginning at the Breitenbush River inflow and connecting to the main branch with a head boundary just downstream of Piety Island in Detroit Lake. The third branch consists of eight segments in the Blowout Creek arm of the lake, and the fourth branch comprises six segments in the Kinney Creek arm. French Creek was modeled as a tributary to the second branch, and Box Canyon Creek was modeled as a tributary to the third branch.

The volume-elevation curve resulting from this model grid was compared to a curve developed for the lake by USACE (fig. 3). From this comparison, the model grid was determined to be an accurate representation of the lake's bathymetry.

\section{Meteorological Data}

CE-QUAL-W2 requires air temperature, dew point temperature, wind speed, wind direction, and solar radiation or cloud cover data. In late September 2002, a Bureau of Reclamation Agrimet weather station was installed just north of Detroit Lake with funding from USACE. Because the entire 2002 calendar year was modeled, a regression was developed for data collected at this weather station and a Remote Automated Weather Station (RAWS) site at Stayton (located approximately $45 \mathrm{~km}$ to the west of Detroit Dam) operated by ODF. This regression was used to extend the record of

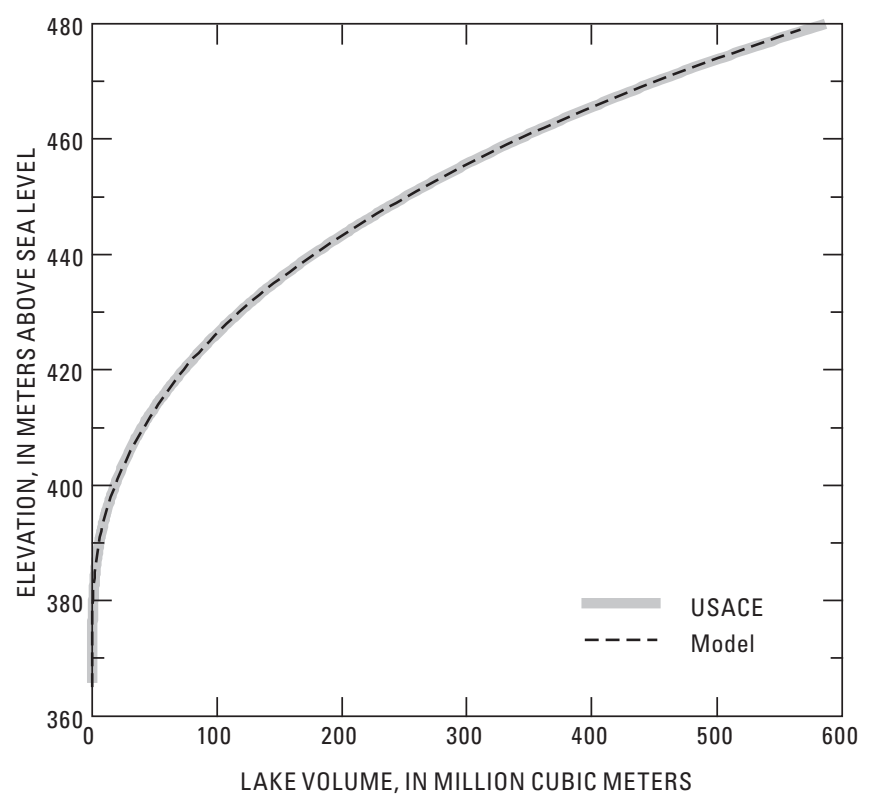

Figure 3. Volume-elevation curves for Detroit Lake, Oregon, from the U.S. Army Corps of Engineers (USACE) and as represented by the model grid.

the Agrimet station back to January 1, 2002. Precipitation at Detroit Dam, reported by the Oregon Climate Service, also was included as input to the Detroit Lake model.

Wind speeds measured at the Agrimet weather station were lower than wind speeds reported on the lake by field crews and estimated by the Beaufort wind force scale, which relates wave heights and descriptions of conditions to wind speed. The lower wind speed at the Agrimet station probably was due to the site's location in a forest clearing, not directly on or adjoining the lake. For the model, wind speed measured at the Stayton RAWS station was used instead; on average, these wind speeds were 10 to 15 times higher than values reported at the Detroit Agrimet station and more consistent with field observations on the lake.

\section{Hydrological Data}

Streamflow was measured at USGS gaging stations at 30-minute intervals on the main inflows to Detroit Lake including the North Santiam River, Breitenbush River, and Blowout Creek for all modeled time periods. French Creek flows were measured in 2002 and 2003, but not during the 2005-06 storms. Kinney and Box Canyon Creeks were not gaged in any of the modeled years. The inflows from these major ungaged tributaries were estimated using the ratio of each stream's watershed area to that of Blowout Creek upstream of the Blowout Creek gaging station and multiplying that ratio by the measured streamflow at the Blowout gaging station. Inflows to Detroit Lake generally were high during winter and spring storms, and low during the summer and early autumn. 
Most releases from Detroit Lake were routed for power generation through two penstocks with a centerline elevation of 427.6 m (U.S. Army Corps of Engineers, 1953). When another outlet was needed to spill water, such as during a large storm, water was released through outlets with a centerline elevation of $408.4 \mathrm{~m}$. These outlet centerline elevations are 50.6 and $69.8 \mathrm{~m}$ below Detroit Lake's full-pool elevation. Water for power generation was withdrawn from the lake during most of the year, but the amount of water withdrawn varied greatly over the course a day; those data were provided by USACE.

The water-surface elevation in Detroit Lake was measured in the forebay, the part of the lake just upstream of the powerhouse, and these data were compared to the modeled forebay elevations for the water balance calibration. The water-surface elevation of Detroit Lake varied by approximately $35 \mathrm{~m}$ in calendar years 2002 and 2003, and almost $30 \mathrm{~m}$ during the 2005-06 storms. The lake generally is filled by the end of May for boating and recreational uses, and gradually is drawn down beginning in September to provide storage for flood control through the winter.

\section{Inflow Water Temperature and Water Quality Data}

Water temperature, specific conductance, and turbidity data were recorded at 30-minute intervals by water quality monitors located in the North Santiam River, Breitenbush River, and Blowout Creek for all modeled years. These constituents were measured in French Creek in 2002 and 2003, but not during the 2005-06 storms. The December 2005-January 2006 French Creek data were estimated through correlations between French Creek and Breitenbush River data for 2002 and 2003. Water temperature, specific conductance, and turbidity were not measured for Kinney or Box Canyon Creeks in any of the modeled time periods. The inflow characteristics of these smaller tributary inflows were assumed to be similar to those in French Creek, which has similar watershed size.

All inflows were relatively cold to start the calendar year, warmed through spring to a maximum temperature in July, and cooled through autumn. Superimposed on this annual water temperature pattern were short term variations due to weather patterns and daily temperature cycles. The temperatures through the year were similar for all gaged inflows, except for Blowout Creek, which could be approximately $5^{\circ} \mathrm{C}$ warmer than the other inflows from June through October in the modeled time periods. This warmer temperature may have to do with sensor placement, and this may be investigated in the future by placing a probe in a different location in Blowout Creek.
Inflow specific conductance was lowest during the winter and spring, and reached a maximum in September to early November, repeating the seasonal shift from rainfall and snowmelt (low conductance) to ground water baseflow (higher conductance). The specific conductance in French Creek was the lowest of all gaged inflows, whereas specific conductance was the highest in Breitenbush River, which has geothermal influence. Some spikes (short-lived positive deviations) in specific conductance in Breitenbush River are currently unexplained (Bragg and Uhrich, 2004). To test whether these spikes affected the model results, they were removed for one model run, but were found to make no difference; therefore, the spikes were left unchanged in the final model inputs.

When using CE-QUAL-W2, it is desirable to simulate TDS instead of specific conductance because the model calculates water density as a function of temperature, TDS, and suspended sediment. Specific conductance and TDS are linearly related (Hem, 1985), because ions from dissolved solids make it possible for water to conduct an electric current. For the Detroit Lake model, then, TDS was simulated using TDS inputs that were converted from specific conductance data. According to Hem (1985), the relation between specific conductance and TDS can be described by: TDS $=(\mathrm{SC}) *$ $\mathrm{A}$, where $\mathrm{SC}$ is specific conductance in microsiemens per centimeter, TDS is in units of milligrams per liter, and A is the slope of the relation between TDS and SC. The value of A generally ranges between 0.55 and 0.75 . For the Detroit Lake model, the value of A was estimated to be 0.67 . This relation was used to interconvert between SC and TDS.

Although turbidity was recorded at 30-minute intervals at many of Detroit Lake's inflows, it is not a constituent that can be directly simulated by CE-QUAL-W2. Turbidity is a measure of the light-scattering properties of a liquid, and often can be directly related to the concentration of suspended particulate material in that liquid. Suspended sediment can be directly simulated by CE-QUAL-W2.

Relations between turbidity and total suspended sediment, and between turbidity and "persistent turbidity" — the long-lasting turbidity due to slowly settling small-sized suspended sediment-have been determined for Breitenbush River, French Creek, North Santiam River, and Blowout Creek (updated from Uhrich and Bragg, 2003; table 1). Concentrations for two sediment-size groups were determined for each inflow, using these relations and the measured 30-minute turbidity data. The larger size group, "sand and silt," was defined as sediment particles with a diameter larger than $2 \mu \mathrm{m}$, and the smaller-size group, "clay," was defined as particles with a diameter less than or equal to $2 \mu \mathrm{m}$. The $2 \mu \mathrm{m}$ cutoff was based on the persistent turbidity analysis by Uhrich and Bragg (2003). Concentrations of suspended sand and silt were obtained by subtracting the estimated concentration of suspended clay from the estimated total suspended sediment concentration. 
Table 1. Regression equations for estimating total and clay-size suspended sediment concentrations from turbidity data for the major tributaries to Detroit Lake, Oregon.

[The concentration of suspended sand and silt was determined by the difference between the estimated total and clay-size suspended-sediment concentrations. Abbreviations: $\mathrm{SS}_{\mathrm{T}}$, total suspended sediment, in milligrams per liter; Tb, Turbidity in FNU; $\mathrm{SS}_{\mathrm{C}}$, Clay-size suspended sediment, in milligrams per liter]

\begin{tabular}{llc}
\hline \multicolumn{1}{c}{ Tributary } & $\begin{array}{c}\text { Total suspended } \\
\text { sediment }\end{array}$ & $\begin{array}{c}\text { Clay-size suspended } \\
\text { sediment }\end{array}$ \\
\hline North Santiam River & $\mathrm{SS}_{\mathrm{T}}=1.98 * \mathrm{~Tb}^{1.02}$ & $\mathrm{SS}_{\mathrm{C}}=1.17 * \mathrm{~Tb}^{0.55}$ \\
Breitenbush River & $\mathrm{SS}_{\mathrm{T}}=2.34 * \mathrm{~Tb}^{0.97}$ & $\mathrm{SS}_{\mathrm{C}}=1.23 * \mathrm{~Tb}^{0.55}$ \\
French Creek & $\mathrm{SS}_{\mathrm{T}}=1.21 * \mathrm{~Tb}^{0.97}$ & $\mathrm{SS}_{\mathrm{C}}=1.23 * \mathrm{~Tb}^{0.55}$ \\
Blowout Creek & $\mathrm{SS}_{\mathrm{T}}=1.64 * \mathrm{~Tb}^{1.08}$ & $\mathrm{SS}_{\mathrm{C}}=2.15 * \mathrm{~Tb}^{0.43}$ \\
\hline
\end{tabular}

\section{Lake Profile Data}

Vertical profiles of water temperature, specific conductance, $\mathrm{pH}$, turbidity, and dissolved oxygen were measured with a multiparameter probe in Detroit Lake approximately every 3 weeks from April 2002 to October 2003, and on January 13, 2006. The probes were calibrated and checked during each field trip. Water samples for suspended sediment analysis were taken at several discrete depths with a Van Dorn sampler. Light profiles were measured with a LI-COR LI-193SA spherical quantum sensor. Secchi depths were determined by lowering a Secchi disk into the water and noting the deepest depth at which the disk pattern could still be distinguished. These data were collected in 2002 and 2003 at three sites in Detroit Lake: Kinney, Blowout, and Mongold (fig. 1). The Kinney site, downstream of the Kinney Creek inflow and the site closest to the dam, is the deepest site. The Blowout site, downstream of the Blowout Creek inflow, is of intermediate depth. The Mongold site, downstream of the confluence of the Breitenbush River and North Santiam River arms, is the shallowest of the three main sites. On January 13, 2006, the vertical profiles were taken at four sites: Kinney, Blowout, Mongold-North, and MongoldSouth. The latter two sites were upstream of the original Mongold site, on either side of Piety Island in Detroit Lake (fig. 1), and were sampled only in 2006. Water temperature at various depths in the lake also was measured using a string of thermistors suspended at varying depths from a log boom near the dam. Data were collected every hour at 23 depths, from 1 to $80 \mathrm{~m}$, from late May 2003 to early October 2003 .

Lake light extinction coefficients, which describe how light is attenuated through the water column, were calculated for each site on each sampling date by three methods using the light profile and Secchi disk data (Sullivan and others, 2006). Light extinction is affected by suspended sediment and algae in the lake, and in turn affects water temperature and the lake heat budget. A seasonal variation in the light extinction coefficient was observed in the lake. The highest light extinction coefficients, approaching $1.0 \mathrm{~m}^{-1}$, occurred in the lake from December through February in 2002 and 2003, presumably due to inflows with high turbidity associated with winter storms. Relatively high light extinction coefficients also were calculated in summer, probably related to algal blooms. The lowest light extinction coefficients occurred in late spring and early autumn. With a regression between average measured suspended sediment concentration in the photic zone and the light extinction data, the light extinction coefficient for water $\left(\lambda_{\mathrm{H} 2 \mathrm{O}}\right)$, and the light extinction factor for suspended sediment $(\varepsilon)$ were calculated to be $0.21 \mathrm{~m}^{-1}$, and $0.14 \mathrm{~m}^{2} / \mathrm{g}$, respectively (table 2). The light extinction coefficient $(\lambda)$ calculated by the model, then, is:

$$
\lambda=\lambda_{\mathrm{H} 20}+\lambda_{\mathrm{SS}}
$$

where:

$\lambda_{\text {H20 }}$ is light extinction coefficient for lake water with no suspended sediment,

$\lambda_{\mathrm{SS}}$ is $\varepsilon * \mathrm{SS}$,

$\varepsilon$ is light extinction factor for suspended sediment, and

SS is suspended sediment concentration.

The fraction of solar radiation absorbed at the water surface $(\beta)$, was set as 0.40 , estimated from the light extinction coefficients and the equation (Cole and Wells, 2002):

$$
\beta=0.27 \ln (\lambda)+0.61 .
$$

Table 2. Model parameters and values used in the Detroit Lake, Oregon, model.

[Abbreviations: $\mathrm{m}$, meter; $\mathrm{m}^{2} / \mathrm{g}$, square meter per gram; ${ }^{\circ} \mathrm{C}$, degree Celsius; $\left(\mathrm{W} / \mathrm{m}^{2}\right) / \mathrm{s}$, watt per square meter per second; $\mathrm{m}^{2} / \mathrm{s}$, square meter per second;

\begin{tabular}{|c|c|c|}
\hline Parameter & Value & Description \\
\hline WSC & 1.0 & Wind sheltering coefficient, dimensionless \\
\hline EXH2O & 0.21 & Light extinction coefficient for water, $\mathrm{m}^{-1}$ \\
\hline EXSS & 0.14 & $\begin{array}{l}\text { Light extinction due to inorganic suspended } \\
\text { solids, } \mathrm{m}^{2} / \mathrm{g}\end{array}$ \\
\hline BETA & 0.40 & $\begin{array}{l}\text { Fraction of solar radiation absorbed at water } \\
\text { surface, dimensionless }\end{array}$ \\
\hline TSED & 11.8 & Sediment temperature, ${ }^{\circ} \mathrm{C}$ \\
\hline CBHE & 0.879 & Coefficient of bottom heat exchange, $\left(\mathrm{W} / \mathrm{m}^{2}\right) / \mathrm{s}$ \\
\hline AZMAX & 0.001 & Maximum vertical eddy viscosity, $\mathrm{m}^{2} / \mathrm{s}$ \\
\hline SSS1 & 21.0 & Large suspended solids settling rate, $\mathrm{m} / \mathrm{d}$ \\
\hline SSS2 & 0.60 & Small suspended solids settling rate, $\mathrm{m} / \mathrm{d}$ \\
\hline
\end{tabular}
$\mathrm{m} / \mathrm{d}$, meter per day] 
To plot and compare model output with measured profile lake data, modeled TDS concentrations were converted to specific conductance by the relation discussed section "Inflow Water Temperature and Water Quality Data." Similarly, measured turbidity data from the vertical profiles were converted to suspended sediment concentrations by developing a relation between measured turbidity and measured suspended sediment in the lake, using data that had been collected at the same depth and the same time. This relation took the form:

$$
\mathrm{SS}_{\mathrm{T}}=0.7893 * \mathrm{~Tb}^{0.8361}, R^{2}=0.72,
$$

where:

$$
\begin{gathered}
\mathrm{SS}_{\mathrm{T}} \text { is total suspended sediment concentration in } \mathrm{mg} / \mathrm{L} \text {, } \\
\text { and }
\end{gathered}
$$

$\mathrm{Tb}$ is turbidity, in FNU (Formazin nephelometric units, FNU, are similar to nephelometric turbidity units, NTU, but are from turbidity measurements made with infrared light, not white light [Anderson, 2005]).

From this regression, the standard error in the predicted suspended sediment concentration for each turbidity was $1.74 \mathrm{mg} / \mathrm{L}$. Thus, the model may not be able to fit suspended sediment concentrations converted from measured turbidity with less error than this, because these derived values have about $1.7 \mathrm{mg} / \mathrm{L}$ of error intrinsic to the estimation.

Goodness-of-fit statistics were calculated between measured profile data and model output at the same location and time. Three statistics were calculated: mean error (ME), mean absolute error (MAE), and root mean square error (RMSE). ME is defined as the average difference between measured data and modeled values and is used as an indication of model bias. MAE is the average of the absolute values of differences between measured data and modeled values. RMSE is the square root of the mean of the squared differences. Both MAE and RMSE give an indication of the magnitude of the model's prediction uncertainty for a typical data point. RMSE is similar to a standard error of the mean for the model's uncertainty.

\section{Outflow Water Temperature and Water Quality Data}

Water temperature, specific conductance, and turbidity were measured at 30-minute intervals in the North Santiam River at Niagara, downstream of Detroit Dam (fig. 1). These data were useful for comparisons to model output for the outflow from Detroit Lake. However, the intervening $6 \mathrm{~km}$ reach between Niagara and the Detroit Lake outflow includes Big Cliff Reservoir and several small unmeasured tributary inflows. Thus, goodness-of-fit statistics were not calculated for these comparisons.

\section{Model Development}

\section{Water Balance}

The first comparison between measured and modeled lake water-surface elevation showed that the inflows initially included in the model did not account for all water entering the reservoir. Additional flows were needed to balance the water budget, especially in the winter during storms. These missing flows could be composed of small ungaged tributaries, overland flow during storms, or ground water seepage. They made up 10.8 percent of the total inflows in 2002, 9.4 percent in 2003, and 20.0 percent for the 2005-06 storms. To account for these ungaged flows, a distributed tributary was added to each branch of the model. The distributed tributary inflows varied through the simulation period, and typically were greatest during storms. In CE-QUAL-W2, a distributed tributary inflow is apportioned to segments along an entire model branch according to segment surface area. The final modeled water-surface elevations, including the distributed tributary inflows, show good agreement with the measured water-surface elevations for 2002, 2003, and the 2005-06 storms (fig. 4).

The missing inflow was judged to be largely surface water on the basis of TDS and hydrologic information, so the water temperature and water quality of the distributed tributary inflows were estimated as 90 percent surface water and 10 percent ground water. Water temperature and water quality for the surface water component of the distributed tributaries were estimated to be the same as the water temperature and water quality of the major tributary for each branch. Ground water temperature was estimated from annual average air temperature at the lake. Ground water TDS concentrations were estimated by examining data from nearby ground water wells and the results of several preliminary model runs. Ground water suspended sediment concentrations were set to zero.

\section{Water Temperature}

Reservoir water temperature patterns are controlled by factors such as the temperature of inflows, the amount of outflow, circulation in the lake, heat exchange at the air-water and sediment-water interfaces, solar radiation, light extinction, and mixing by wind. Detroit Lake typically is isothermal and cold at the beginning of the year (fig. 5). In spring, the surface begins to warm, and by summer a thermocline develops, separating warmer, less dense surface water (epilimnion) from cooler, denser, bottom waters (hypolimnion). The thermocline progressively deepens through the summer; this is an important influence on lake circulation through the summer season. In autumn, the water surface cools, lessening the 


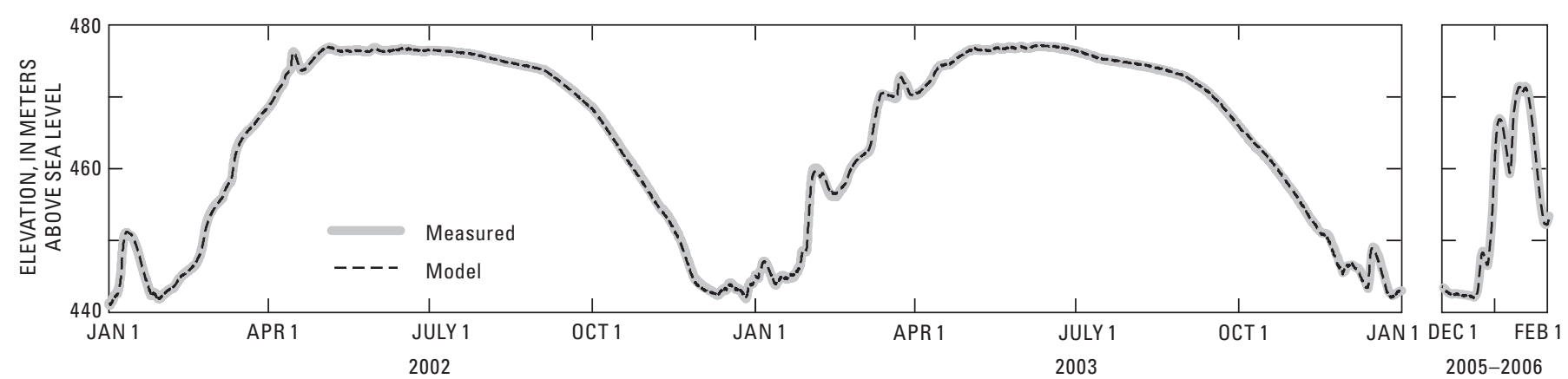

Figure 4. Measured and modeled forebay water-surface elevations, Detroit Lake, Oregon, calendar years 2002 and 2003 , and the period between December 1, 2005, and February 1, 2006.

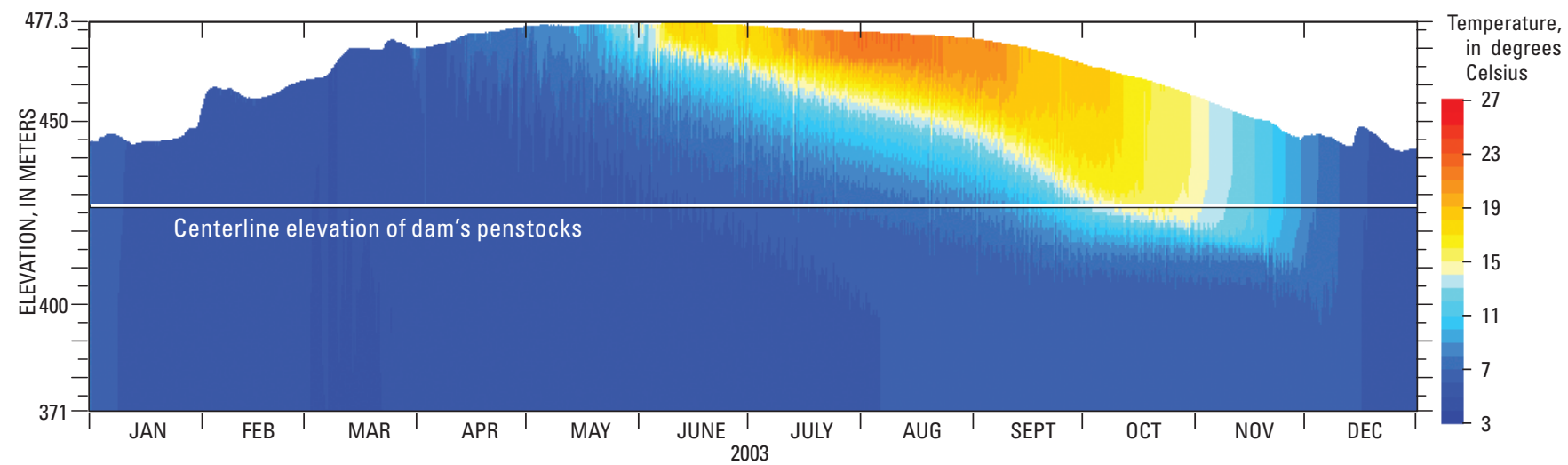

Figure 5. Modeled water temperature profiles in Detroit Lake, Oregon, near the dam as a function of time during 2003.

density differences and allowing vertical mixing ("turnover") to occur. The lake usually is in an isothermal state by the end of the calendar year.

In Detroit Lake, this seasonal pattern in water temperature repeats on an annual basis and was consistent in the modeled time periods (figs. $6, \underline{7}$, and $\underline{8}$ ). Despite differing locations and water depths, temperature patterns were similar for all profile sites in the lake. The consistency of the vertical temperature profiles year-to-year and site-to-site within the lake demonstrates the importance of density patterns in creating a vertical structure within the lake. Temperature is the most important factor influencing water density in Detroit Lake, and, therefore, is among the most important factors in determining its circulation patterns.

Wind also is important in creating a well-mixed layer near the lake surface. The stronger the wind, the deeper is the mixed layer. Several of the profiles in figures 6 and 7 show this effect. The profiles on June 19, 2003, for example, show a well-mixed layer 5 or more meters deep, more so near the dam, where the winds typically are stronger. Such spatial differences in wind speed were not provided by the model's inputs, so the model was unable to capture such subtleties. Overall, however, the model captured the spatial and temporal patterns in the lake's water temperature and its vertical structure.

Surface waters showed the greatest seasonal variation in temperature and the warmest summer temperatures, while the deepest waters of Detroit Lake remained cold through the summer (fig. 9). As water depth increased, the timing of the seasonal maximum water temperature shifted to later in the year, from early August near the surface to early October at $40 \mathrm{~m}$. Measured temperatures at 9-40 $\mathrm{m}$ depth show larger daily variations than those at the surface or near the bottom. This is likely due to those thermistors being stationed closer to the thermocline, the region where the temperature changes rapidly with depth, combined with the phenomenon of the lake's internal waves caused by wind or short-term variations in water withdrawals, which causes the thermocline to move up and down. Temperatures near the surface have less daily variation owing to the depth of the mixed layer, but have a more chaotic signal that is tied to patterns in the wind, creating some of the short-duration spikes in these data. 
KINNEY
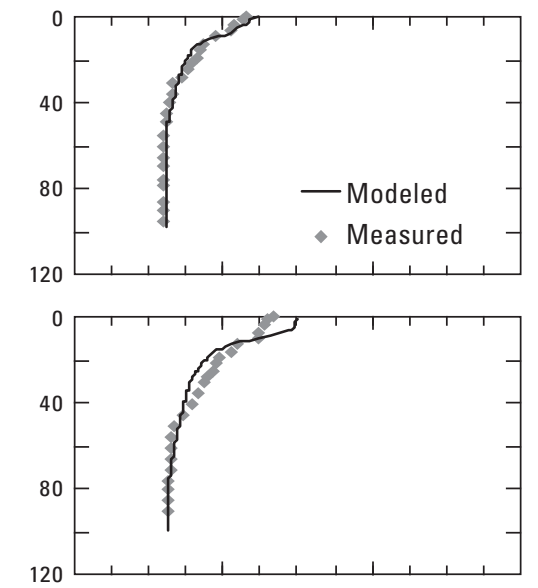

June 12

June 26

July 18

\section{August 6}
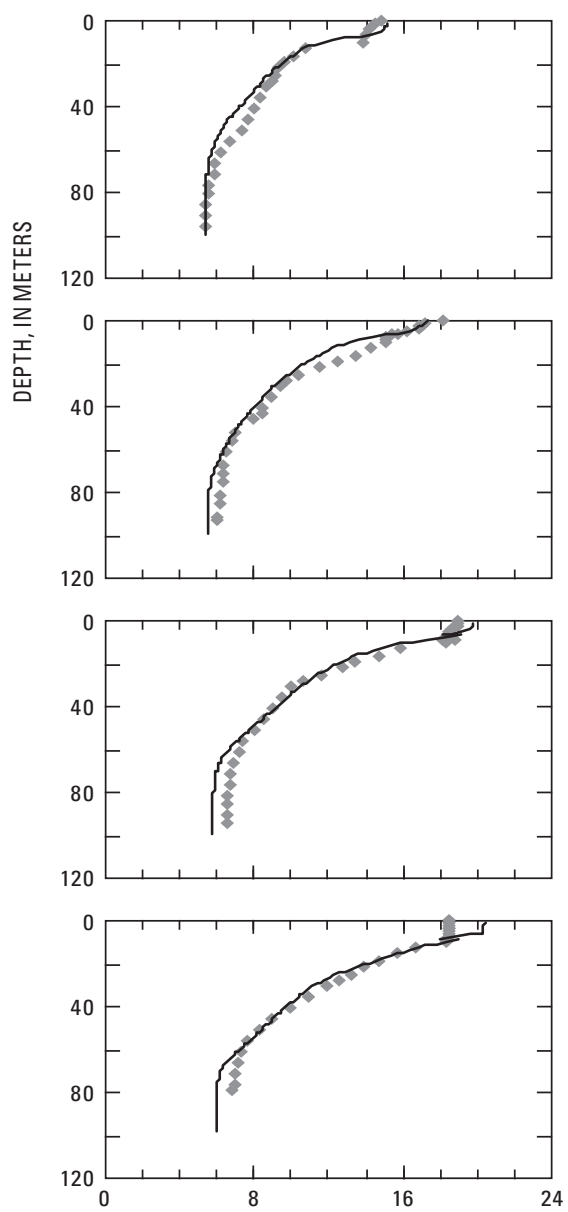

BLOWOUT
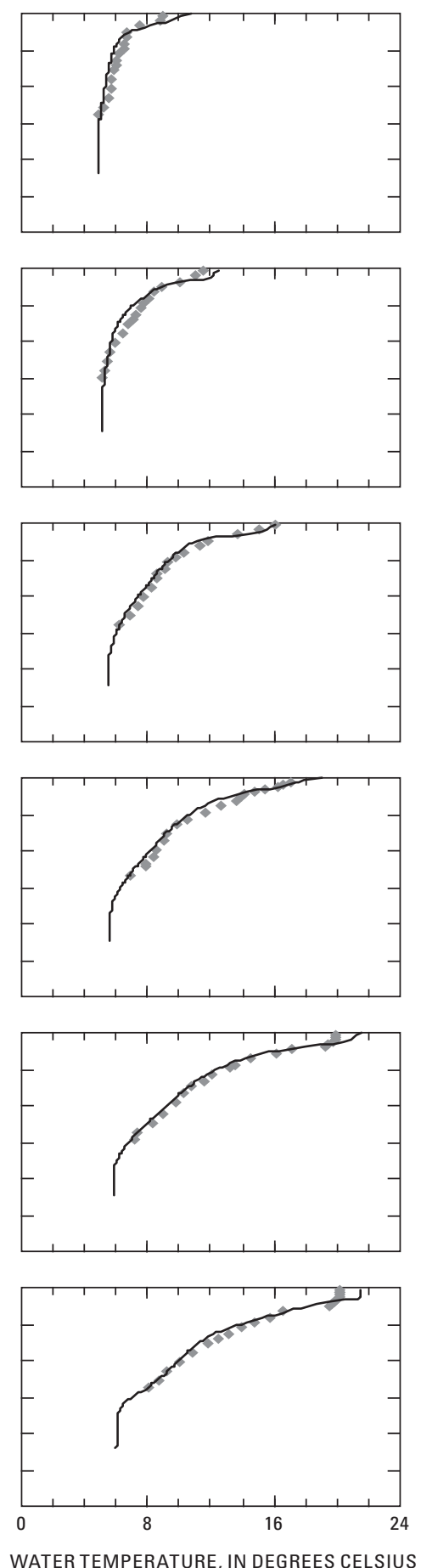

MONGOLD
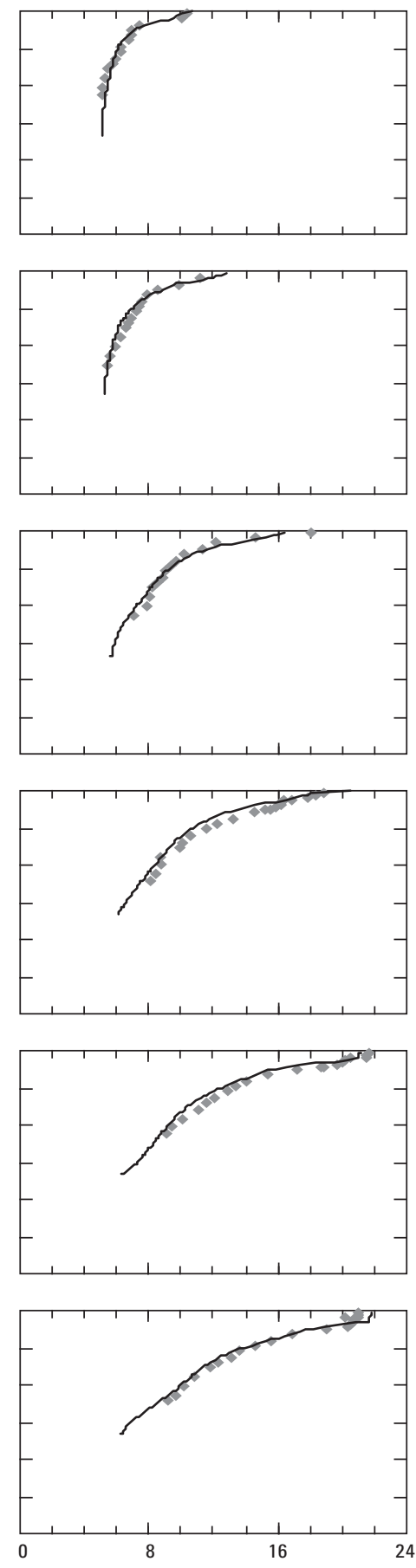

Figure 6. Measured water temperature profiles at three locations in Detroit Lake, Oregon, compared to modeled water temperature at the same location and time in 2002. Model output extends to the bottom of the lake at each location. 
KINNEY

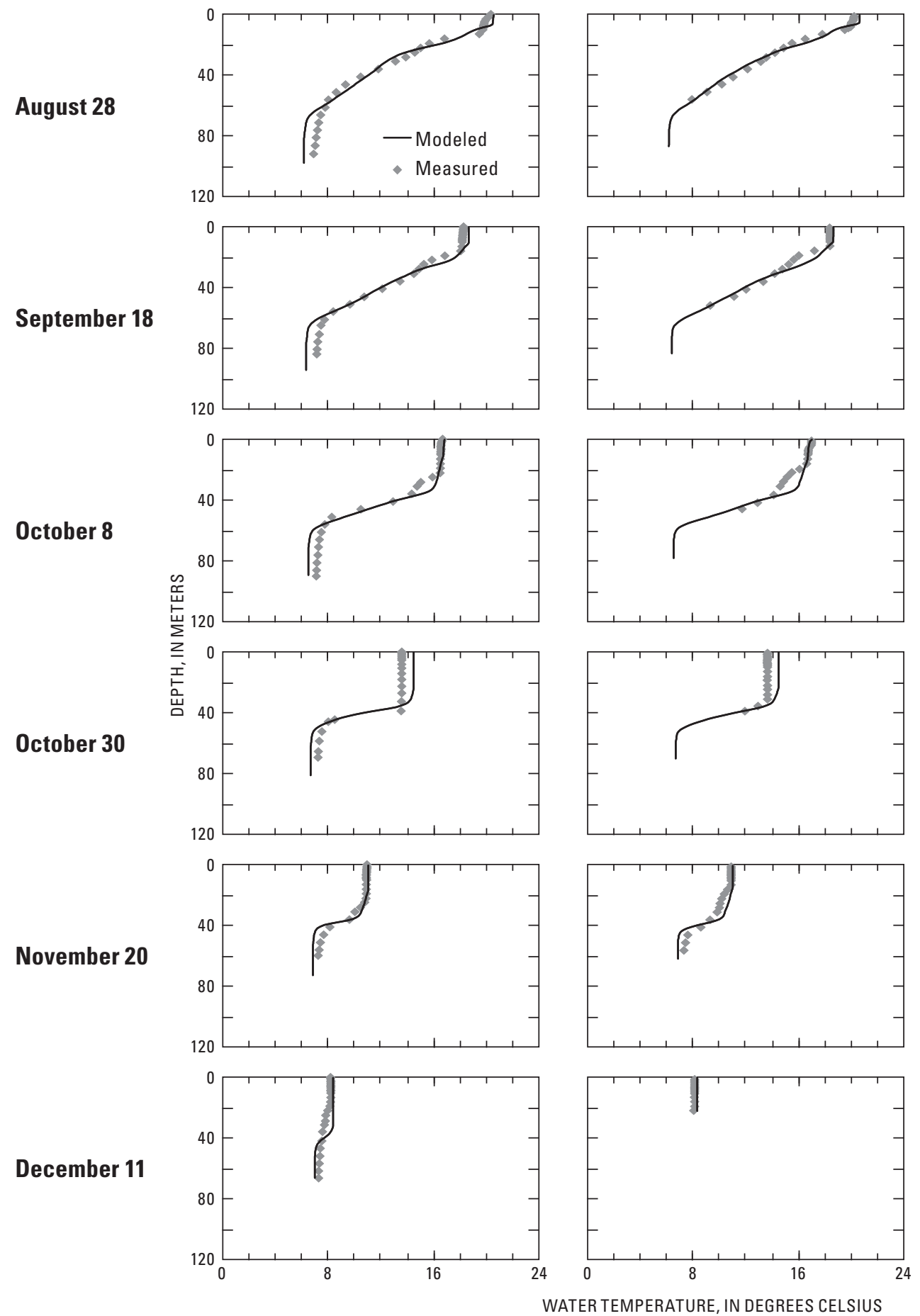

MONGOLD
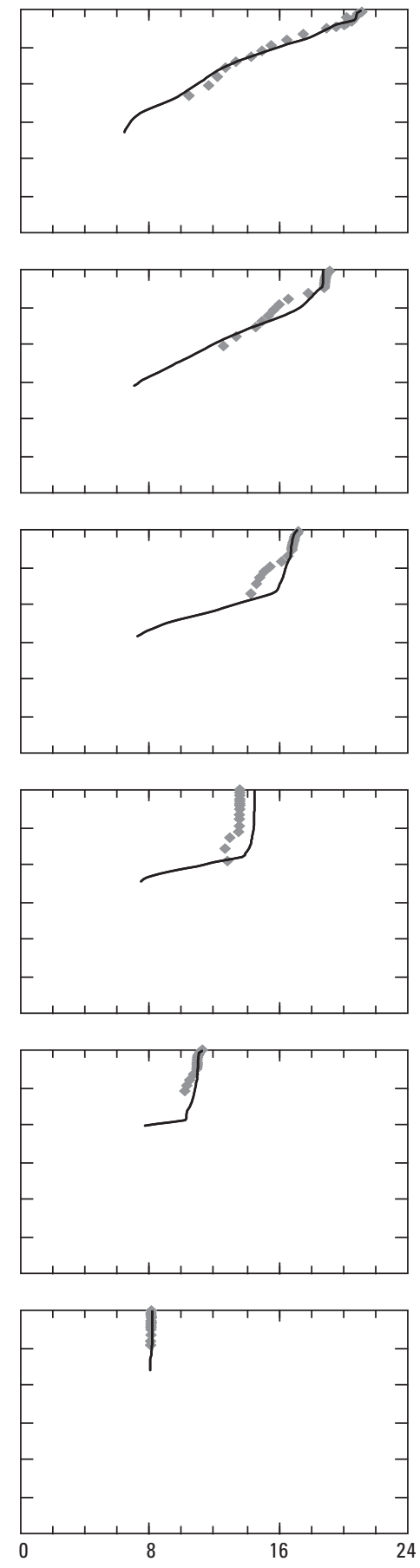

Figure 6.-Continued. 
2003

KINNEY
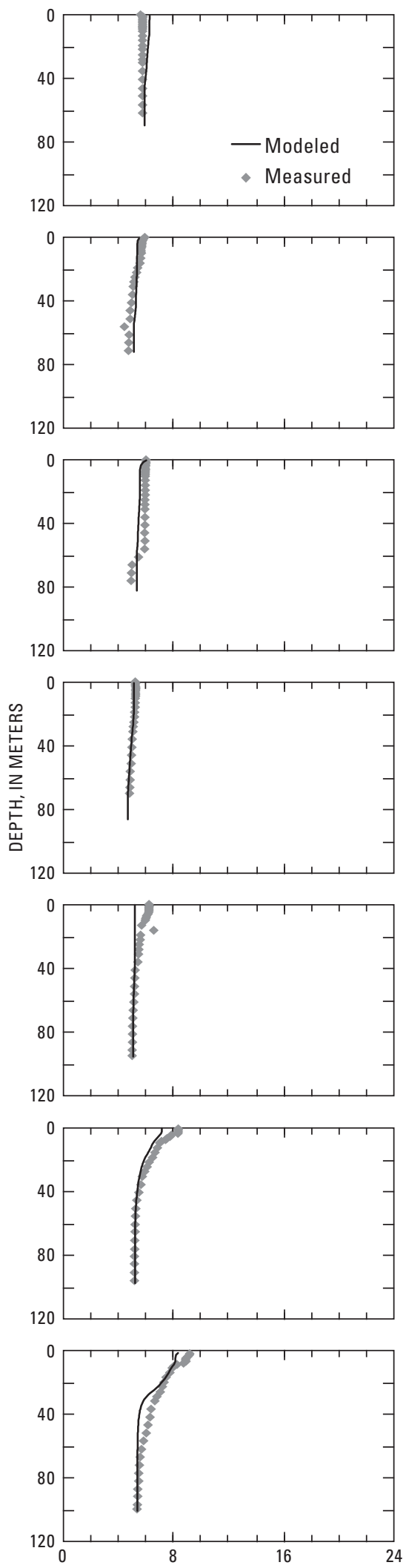

BLOWOUT
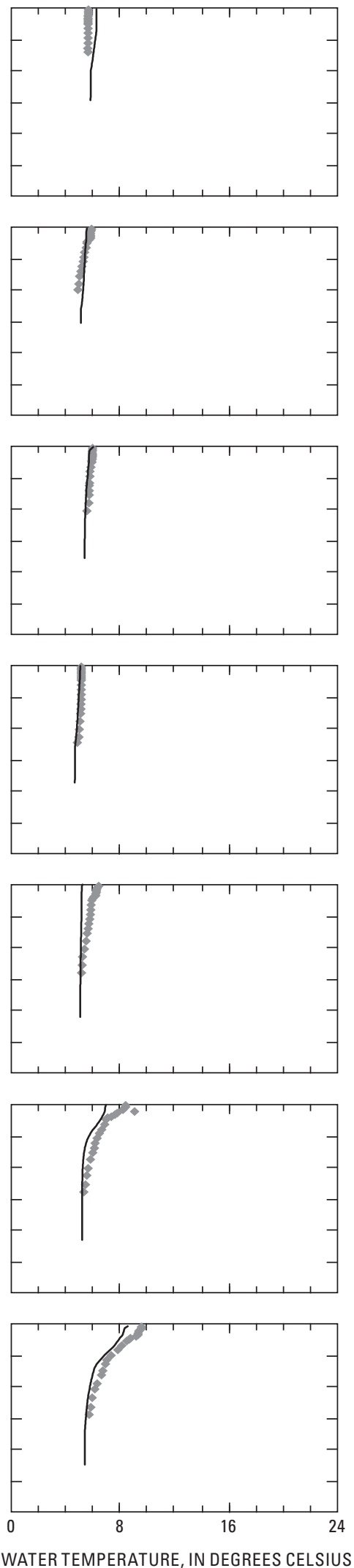

MONGOLD
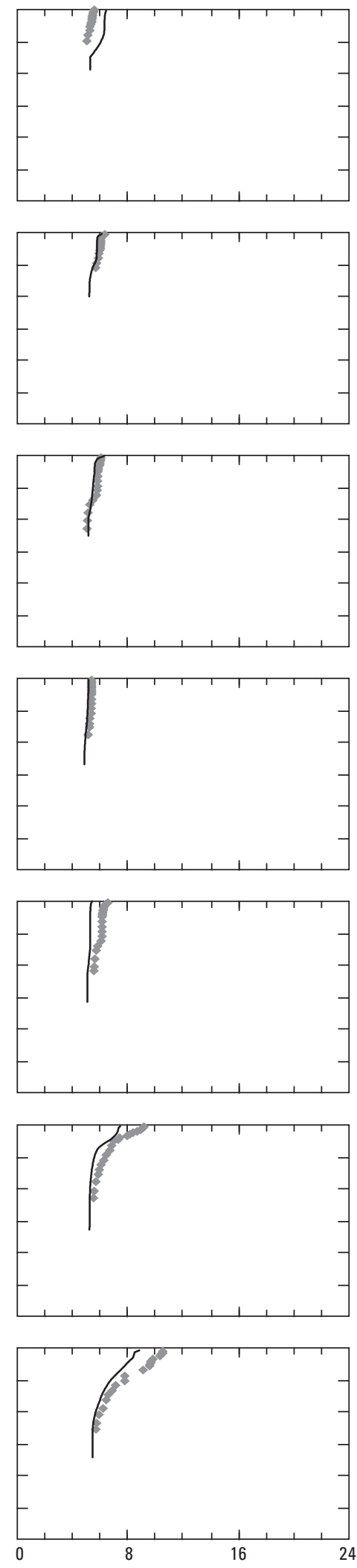

Figure 7. Measured water temperatures profiles at three locations in Detroit Lake, Oregon, compared to modeled water temperature at the same location and time in 2003. Model output extends to the bottom of the lake at each location. 

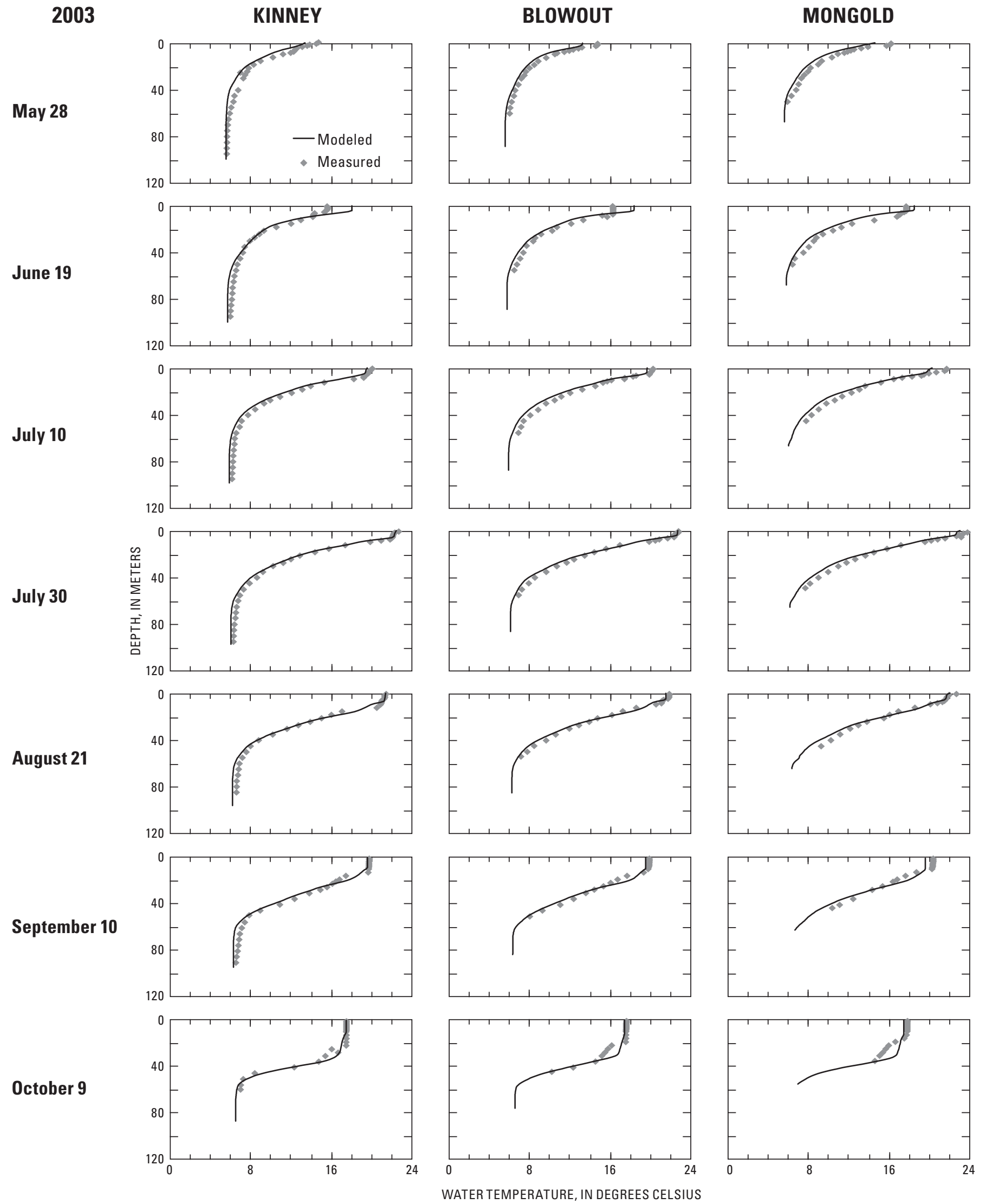

Figure 7.-Continued.

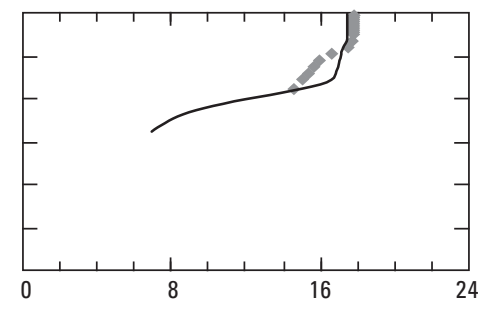


14 Modeling Hydrodynamics, Water Temperature, and Suspended Sediment in Detroit Lake, Oregon

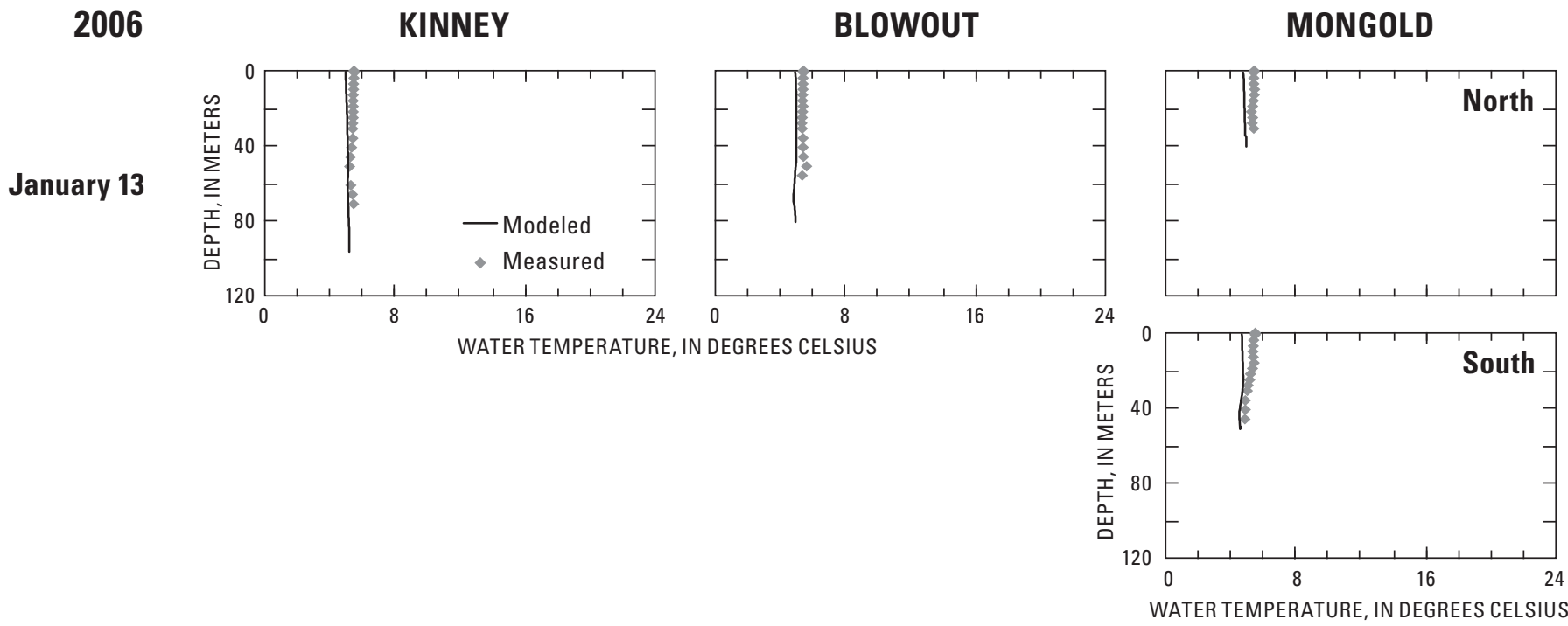

Figure 8. Measured water temperature profiles at four locations in Detroit Lake, Oregon, compared to modeled water temperature at the same location and time in 2006. Model output extends to the bottom of the lake at each location. 

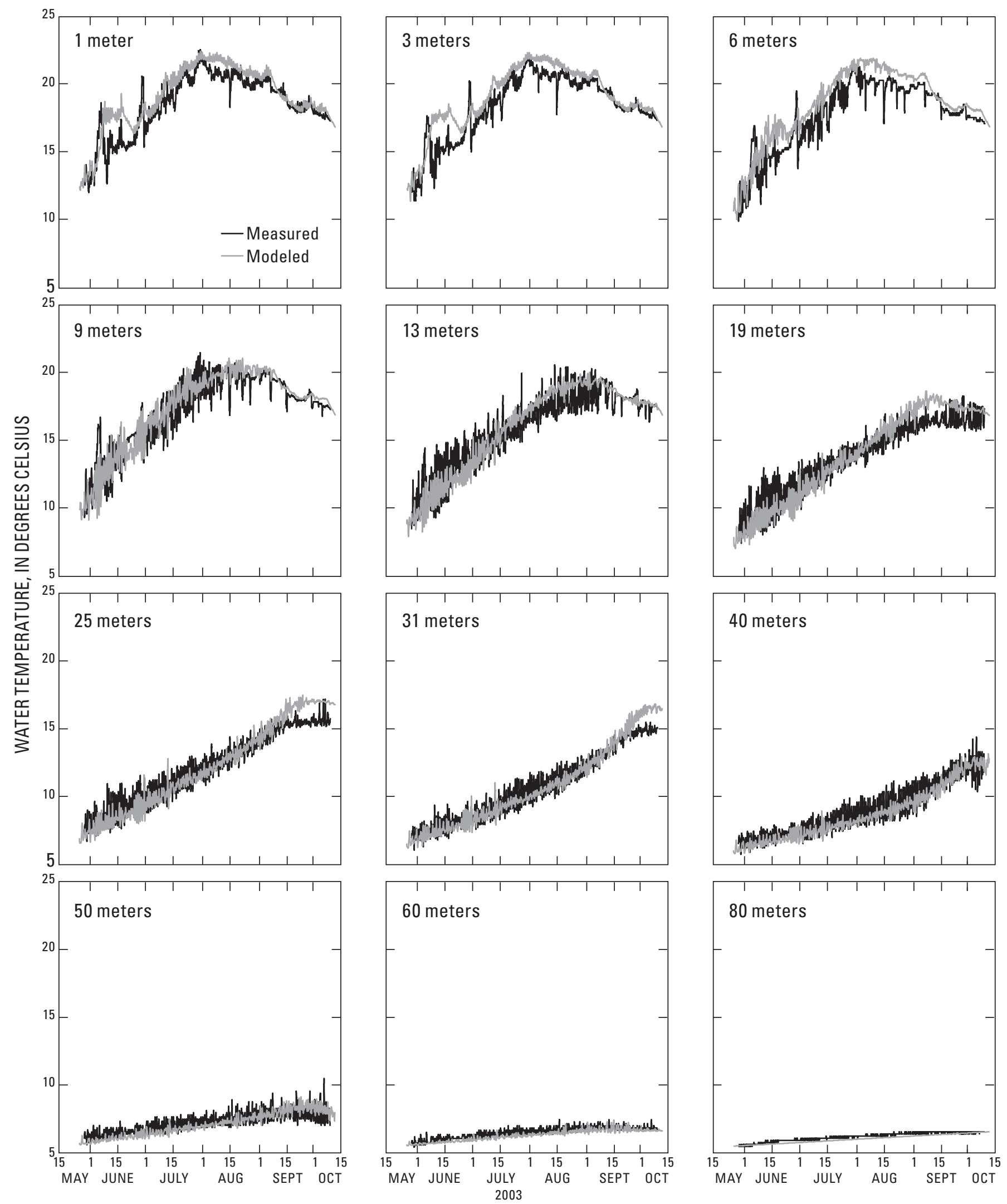

Figure 9. Measured water temperatures from a string of thermistors suspended from the log boom in Detroit Lake, Oregon, compared to modeled water temperature at the same depth and time in 2003. The depth of each thermistor is noted on each graph. 
The reservoir, with a relatively low-elevation outlet, released cold water through the summer (fig. 10). The heat that was stored in the upper part of the water column during summer was discharged later in the year when the reservoir was drawn down for flood control purposes. Consequently, outflow water temperatures were coolest in winter and spring, stayed cool through summer, and were warmest in autumn. The difference in temperature between the modeled reservoir outflow and the measured temperature on the North Santiam River $6 \mathrm{~km}$ downstream (at Niagara) was due in part to airwater heat exchange between the two locations-warming in summer and cooling in autumn. In addition, several small tributaries that enter the river between the reservoir outflow and the measuring location on the North Santiam River at Niagara might contribute to the temperature difference in figure 10 .

Goodness-of-fit statistics were calculated between measured data and model output at the same location and time. For water temperature profiles in the lake, comparing modeled and measured water temperatures for the three time periods (2002, 2003, 2005-06) produced ME between -0.02 and $-0.48^{\circ} \mathrm{C}$, MAE between 0.48 and $0.58^{\circ} \mathrm{C}$, and RMSE between 0.51 and $0.76^{\circ} \mathrm{C}$ (table 3). For the thermistor string near the dam in 2003, comparing modeled and measured water temperatures for all 23 depths produced a ME of $0.24^{\circ} \mathrm{C}$, a MAE of $0.72^{\circ} \mathrm{C}$, and a RMSE of $0.99^{\circ} \mathrm{C}$. Sources of error in simulating water temperature include estimating inflow water temperatures for Kinney and Box Canyon Creeks as well as the ungaged (distributed) tributaries for all simulations, and estimating inflow water temperatures for French Creek for the 2005-06 storm simulations. In addition, measured data showed that light extinction coefficients were elevated in summer coincident with algal blooms. The model, however, did not include algae, and therefore those higher summer light extinctions due to algal activity were not simulated. Despite these sources of error, the goodness-of-fit statistics indicate very good performance by the model in capturing temperature patterns in the lake. Previous CE-QUA1-W2 models have demonstrated the capability of simulating reservoir temperatures to within $1.0^{\circ} \mathrm{C}$ (MAE) (Cole and Wells, 2002). Error greater than that amount is indicative of problems either with the model or the data; MAE of less than $1.0^{\circ} \mathrm{C}$ has become a benchmark for a well-calibrated CE-QUAL-W2 model.

\section{Total Dissolved Solids}

The concentration of total dissolved solids (TDS) represents the sum of all dissolved constituents in water. TDS was included in the Detroit Lake model primarily to more accurately model suspended sediment, because TDS contributes to density gradients in a reservoir. TDS also provides information on lake water quality. CE-QUAL-W2 considers TDS to be conservative (nonreactive), meaning that its concentration is affected only by inputs, outputs, and hydrodynamic processes, not by chemical or biological processes. Some of the constituents that make up TDS, however, may not be completely conservative. For instance, nutrients may be taken up or excreted by algae, dissolved constituents may precipitate as solids, or solids may dissolve from suspended or bottom sediments. In any case, available data were insufficient to model each dissolved constituent individually in this system.

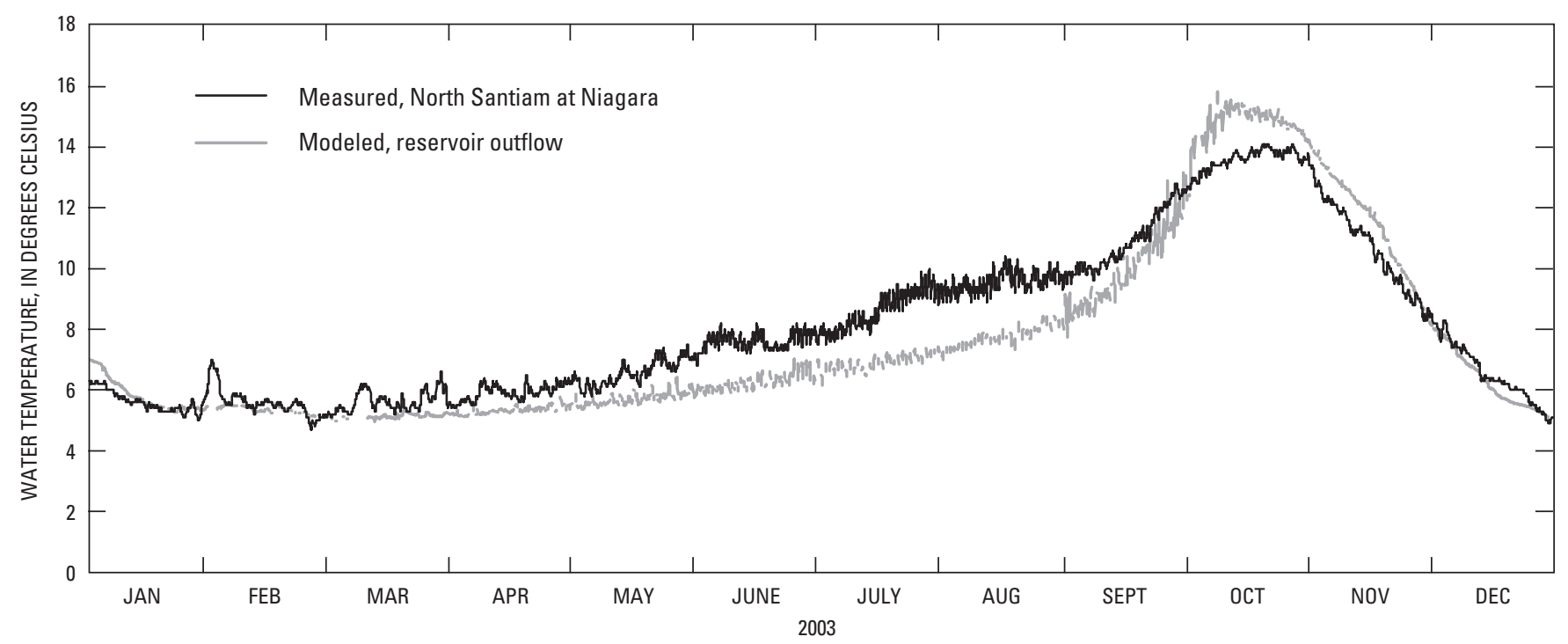

Figure 10. Modeled water temperatures in the Detroit Lake, Oregon, reservoir outflow compared to measured water temperature in the North Santiam River at Niagara, 6 km downstream of the reservoir outflow in 2003. 
Table 3. Detroit Lake model goodness-of-fit statistics for calendar years 2002 and 2003 and a storm event in January 2006.

[Comparisons include profiles at three locations in the lake in 2002 and 2003, and at four locations in 2006. Abbreviations: ${ }^{\circ} \mathrm{C}$, degree Celsius; mg/L, milligram per liter; $\mu \mathrm{S} / \mathrm{cm}$, microsiemens per centimeter]

\begin{tabular}{|c|c|c|c|}
\hline & $\begin{array}{l}\text { Year } \\
2002\end{array}$ & $\begin{array}{l}\text { Year } \\
2003\end{array}$ & $\begin{array}{c}\text { January } \\
2006\end{array}$ \\
\hline Number of profiles & 36 & 42 & 4 \\
\hline \multicolumn{4}{|l|}{ Mean Error (ME) } \\
\hline Temperature $\left({ }^{\circ} \mathrm{C}\right)$ & -0.02 & -0.34 & -0.48 \\
\hline Specific conductance $(\mu \mathrm{S} / \mathrm{cm})$ & 1.49 & 1.32 & -0.15 \\
\hline Suspended sediment $(\mathrm{mg} / \mathrm{L})$ from turbidity & -0.24 & -0.25 & 0.17 \\
\hline Suspended sediment $(\mathrm{mg} / \mathrm{L})$ & -0.61 & -0.45 & -1.68 \\
\hline \multicolumn{4}{|l|}{ Mean Absolute Error (MAE) } \\
\hline Temperature $\left({ }^{\circ} \mathrm{C}\right)$ & 0.52 & 0.58 & 0.48 \\
\hline Specific conductance $(\mu \mathrm{S} / \mathrm{cm})$ & 2.11 & 1.74 & 1.31 \\
\hline Suspended sediment $(\mathrm{mg} / \mathrm{L})$ from turbidity & 0.55 & 0.43 & 3.06 \\
\hline Suspended sediment (mg/L) & 0.91 & 0.80 & 3.34 \\
\hline \multicolumn{4}{|l|}{ Root Mean Square Error (RMSE) } \\
\hline Temperature $\left({ }^{\circ} \mathrm{C}\right)$ & 0.69 & 0.76 & 0.51 \\
\hline Specific conductance $(\mu \mathrm{S} / \mathrm{cm})$ & 2.42 & 2.55 & 3.13 \\
\hline Suspended sediment $(\mathrm{mg} / \mathrm{L})$ from turbidity & 0.73 & 0.68 & 4.28 \\
\hline Suspended sediment $(\mathrm{mg} / \mathrm{L})$ & 1.16 & 1.04 & 3.92 \\
\hline
\end{tabular}

TDS concentrations in Detroit Lake were fairly homogeneous in winter (fig. 11). Inflow waters in spring had lower dissolved solids concentrations compared to the lake water, and decreased the TDS concentration throughout the lake. Through summer and autumn, the TDS concentrations in the inflows increased. At that time of year, temperature stratification was present in the reservoir, and the higher concentration inflow waters were not mixed into the colder, denser, hypolimnetic water. Later in the year, when the lake turned over, the higher TDS in the epilimnion mixed into the entire lake.

This seasonal cycle in TDS was similar in all modeled time periods (shown as specific conductance in figs. 12, 13, and 14). There were some differences between sampling sites in the lake. For instance, the most upstream site, Mongold, showed the greatest effect from the tributary inflows. At that location, the plume of inflow water generally was at depths of $15-40$ $\mathrm{m}$. These influent plumes that enter the lake at specific depths according to their density are important in determining circulation patterns in the regions of these inflows.

Water released from the reservoir outflow reflects the TDS seasonal cycle in the lake, with lowest values in spring and highest values in late autumn and early winter (reported as specific conductance in fig. 15). The overall trends of measured and modeled specific conductance downstream of the dam compare well, despite the fact that measured specific conductance on the North Santiam River at Niagara is $6 \mathrm{~km}$ downstream of the modeled reservoir outflow. The measured data were less smooth compared to the modeled outflow. Part of this difference is due to the entrance of several small tributaries between Detroit Dam and Niagara, and part of the difference is due to dam operation. For instance, at Niagara in spring, two short periods occur where the measured specific conductance decreased to about $25 \mu \mathrm{S} / \mathrm{cm}$. These correspond to periods when no water was released from Detroit Dam, and the small tributaries between Detroit Dam and Niagara appeared to have lower specific conductance values than the reservoir outflow at that time of year. Note that the comparison of specific conductance data downstream of Detroit Dam is better than the same comparison for temperature (fig. 10). This primarily is due to the largely conservative nature of specific conductance; unlike water temperature, it is not affected by exchange processes across the airwater interface.

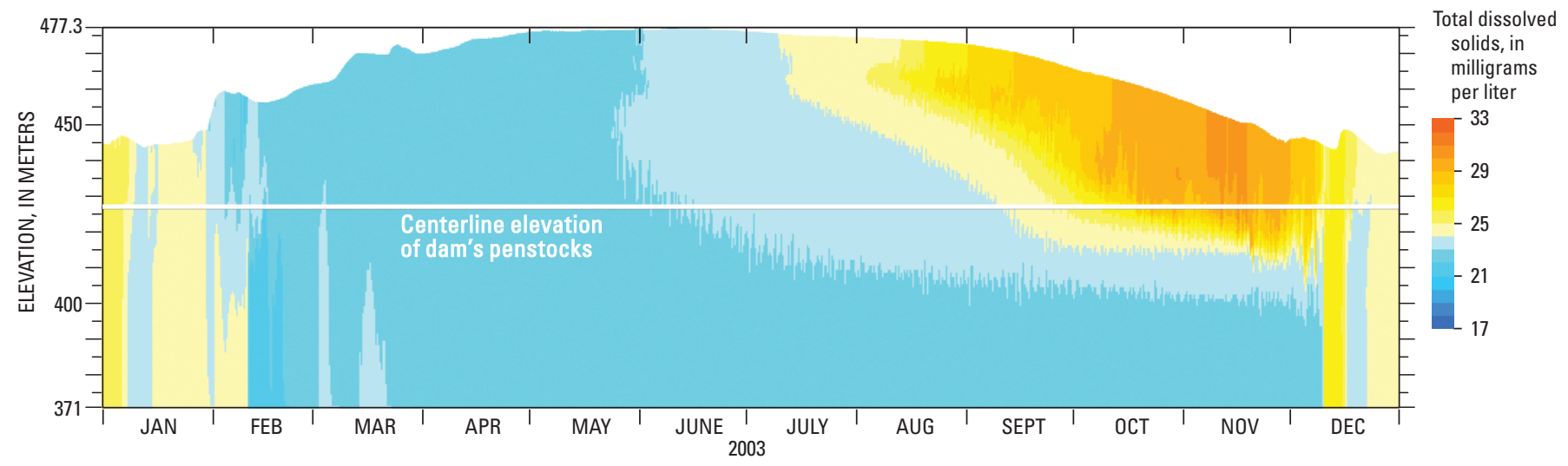

Figure 11. Modeled total dissolved solids profiles in Detroit Lake, Oregon, near the dam as a function of time during 2003. 
2002

April 25

May 16

June 12

June 26

July 18

August 6
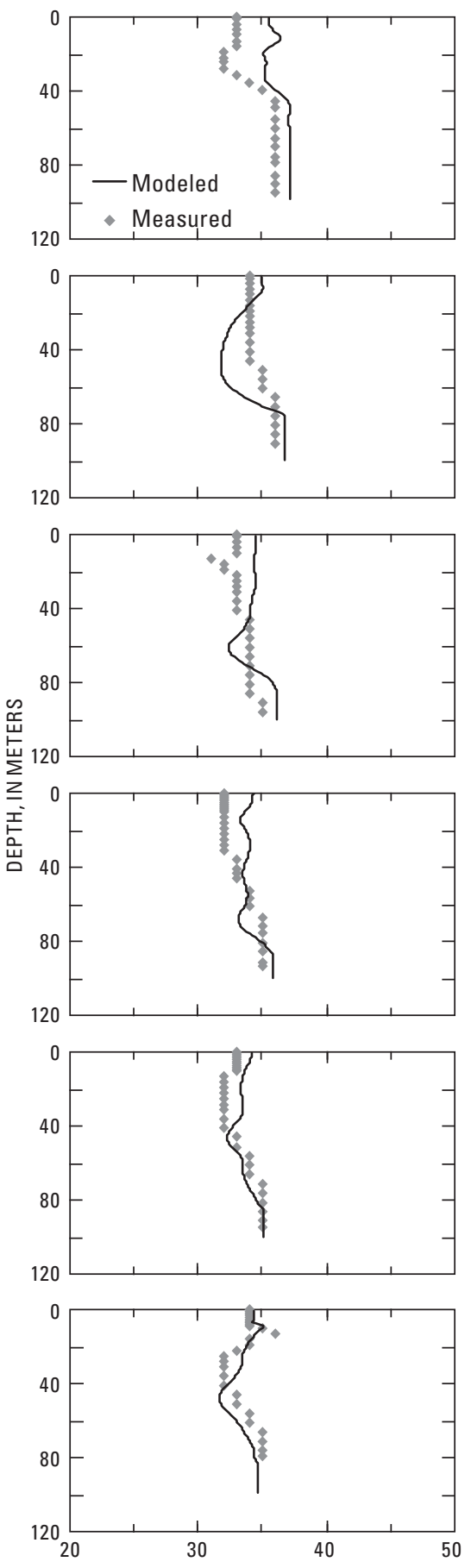

BLOWOUT
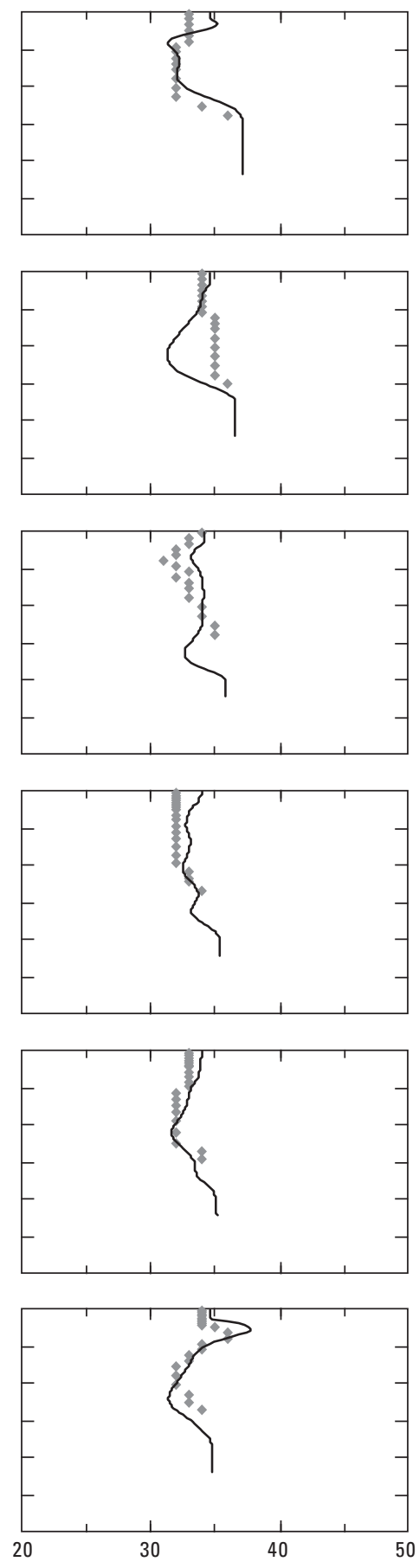

MONGOLD
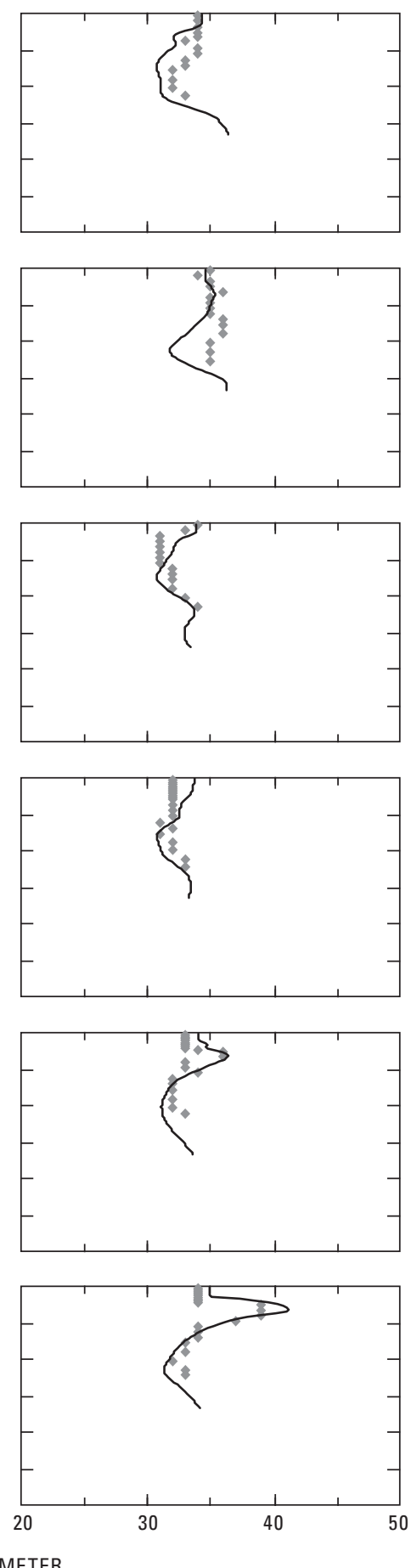

Figure 12. Measured specific conductance profiles at three locations in Detroit Lake, Oregon, compared to modeled specific conductance (derived from total dissolved solids) at the same location and time in 2002. Model output extends to the bottom of the lake at each site. 


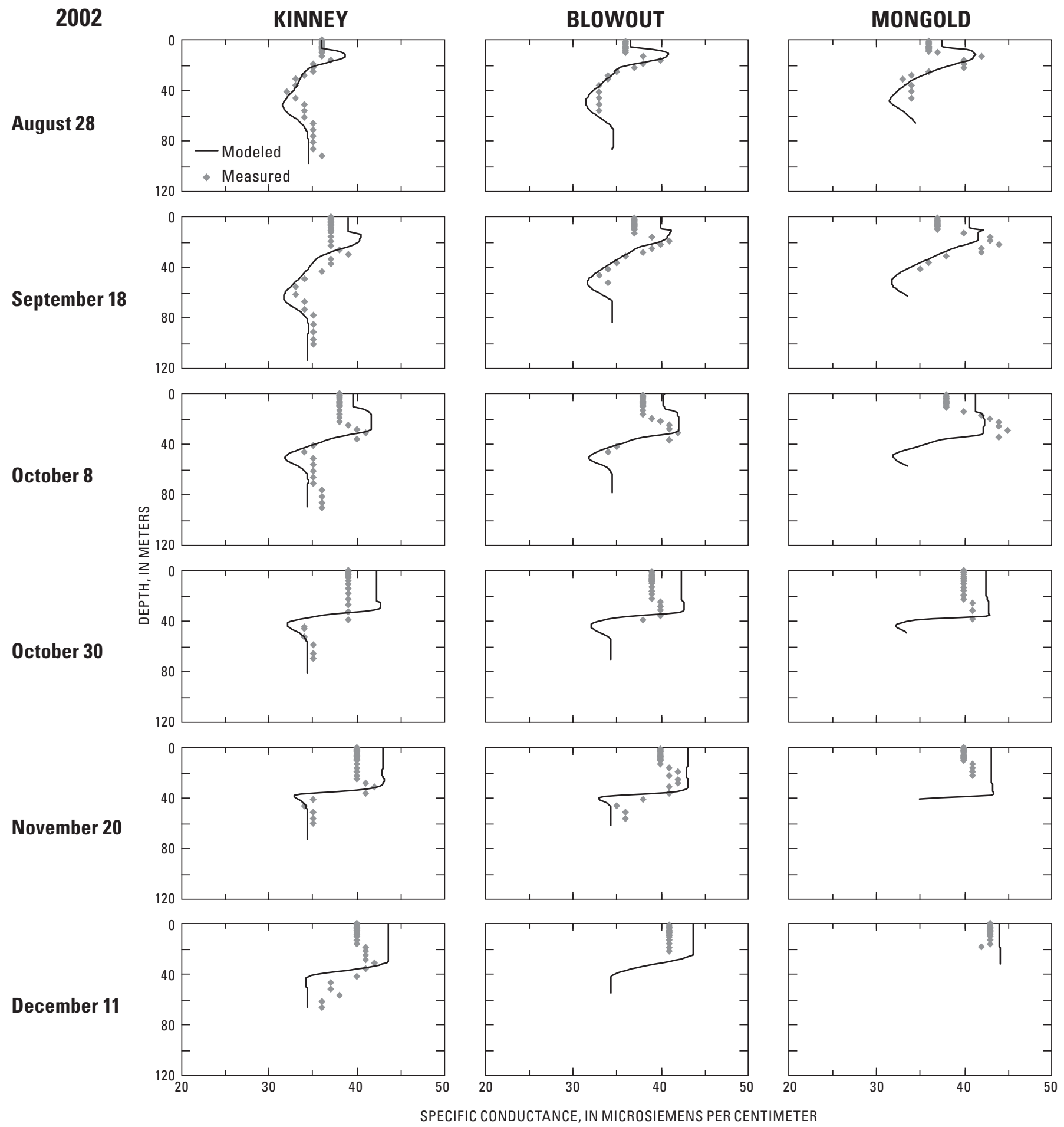

Figure 12.-Continued. 
2003

KINNEY

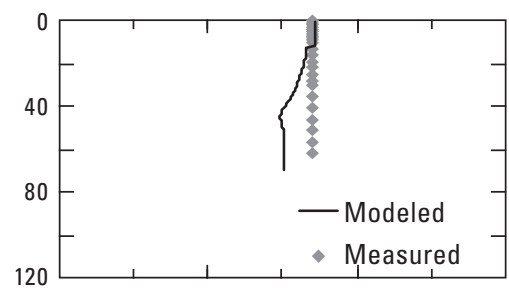

January 28

February 6

March 5

March 27

April 17

May 8
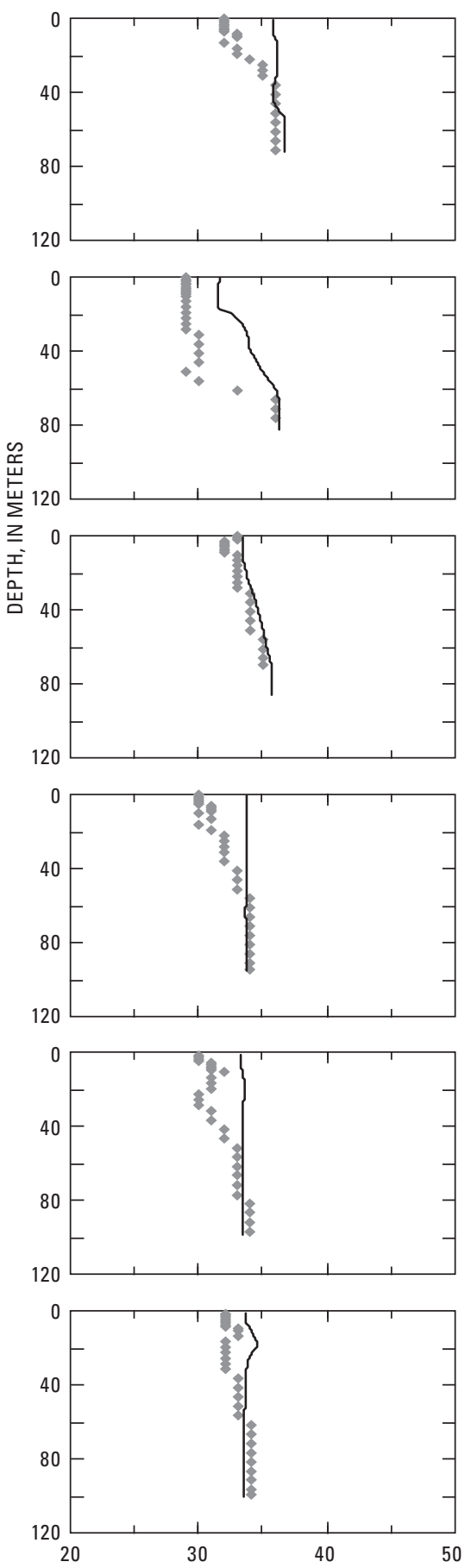

BLOWOUT
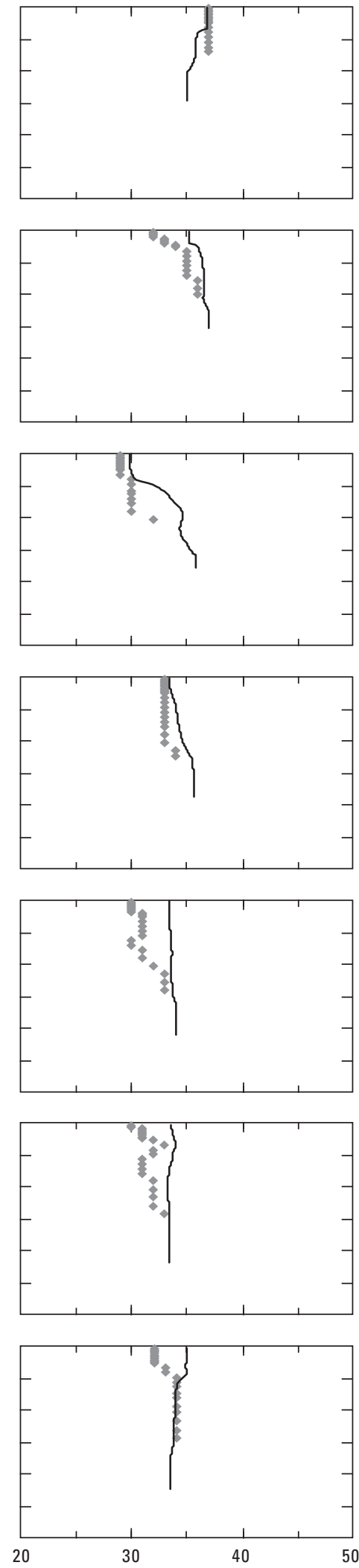

MONGOLD
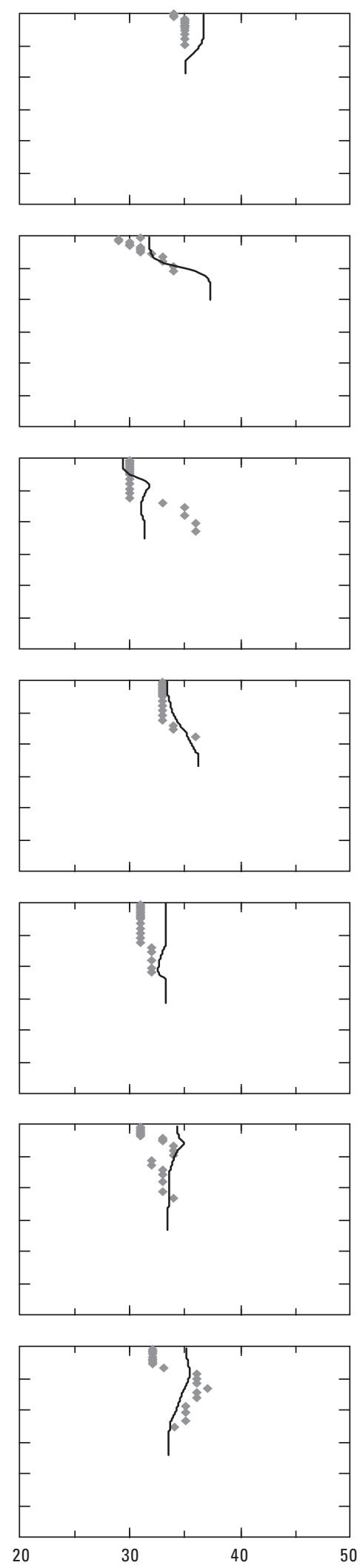

SPECIFIC CONDUCTANCE, IN MICROSIEMENS PER CENTIMETER

Figure 13. Measured specific conductance profiles at three locations in Detroit Lake, Oregon, compared to modeled specific conductance (derived from total dissolved solids) at the same location and time in 2003. Model output extends to the bottom of the lake at each site. 
KINNEY

May 28

June 19

July 10

July 30
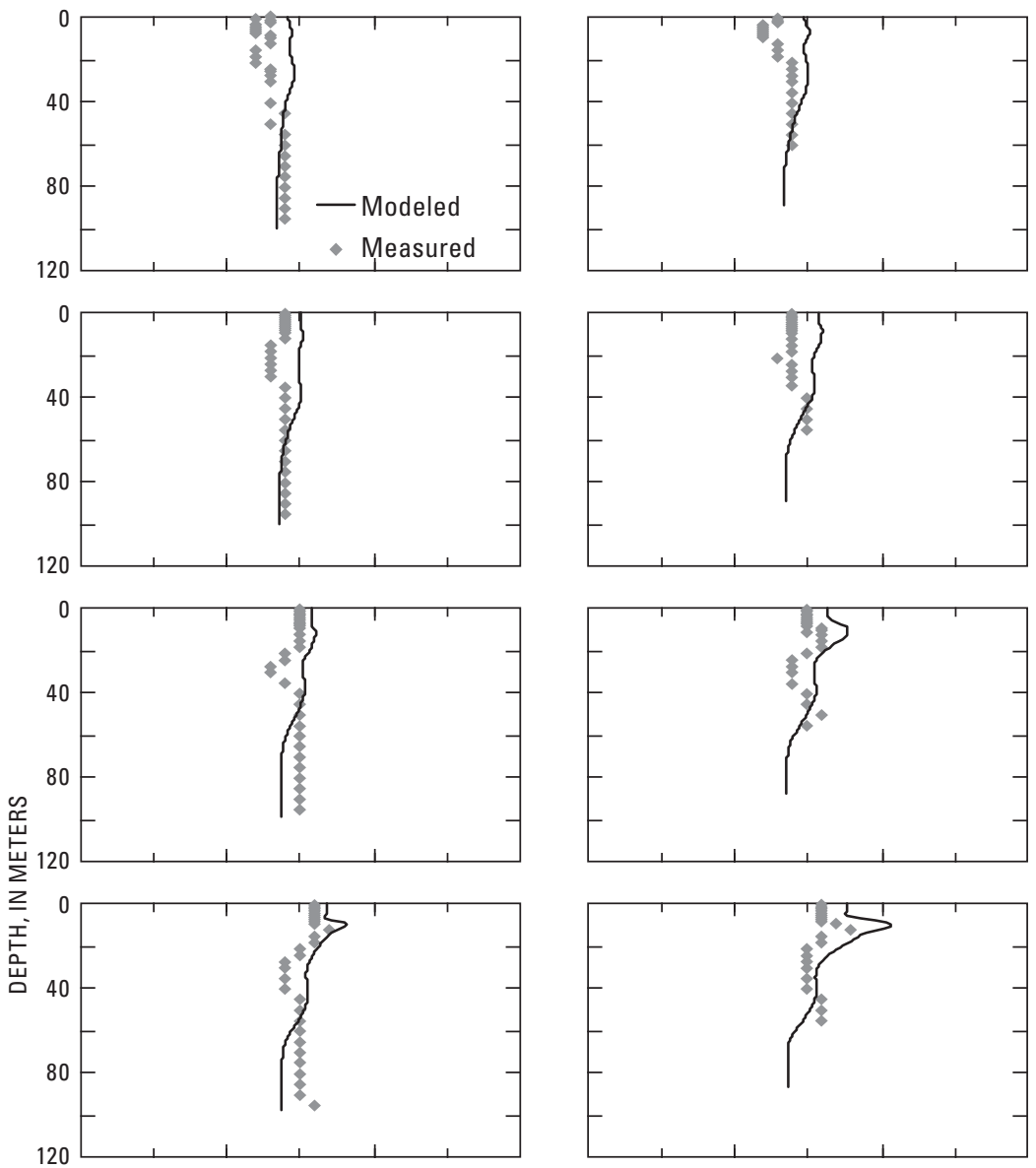

August 21

September 10
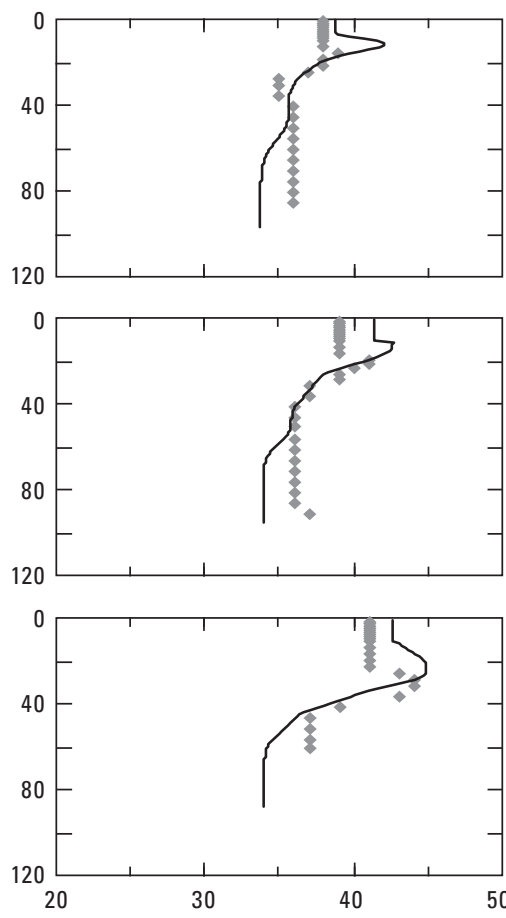
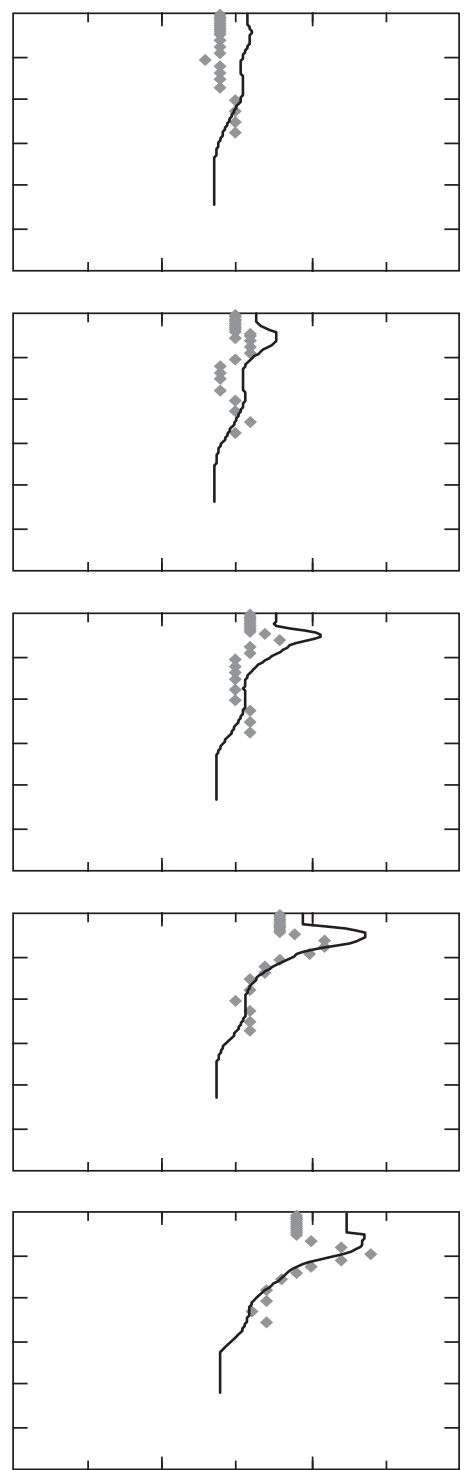

BLOWOUT
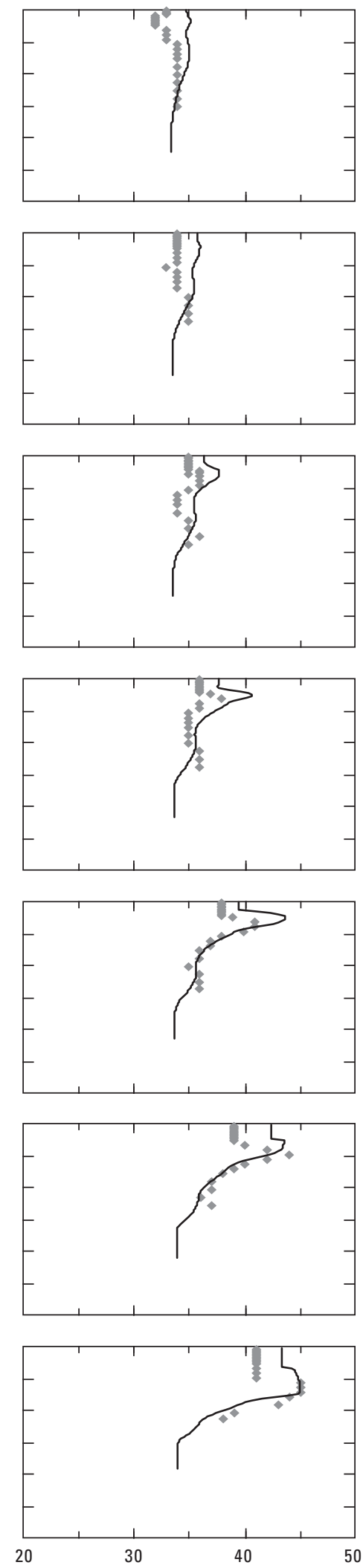
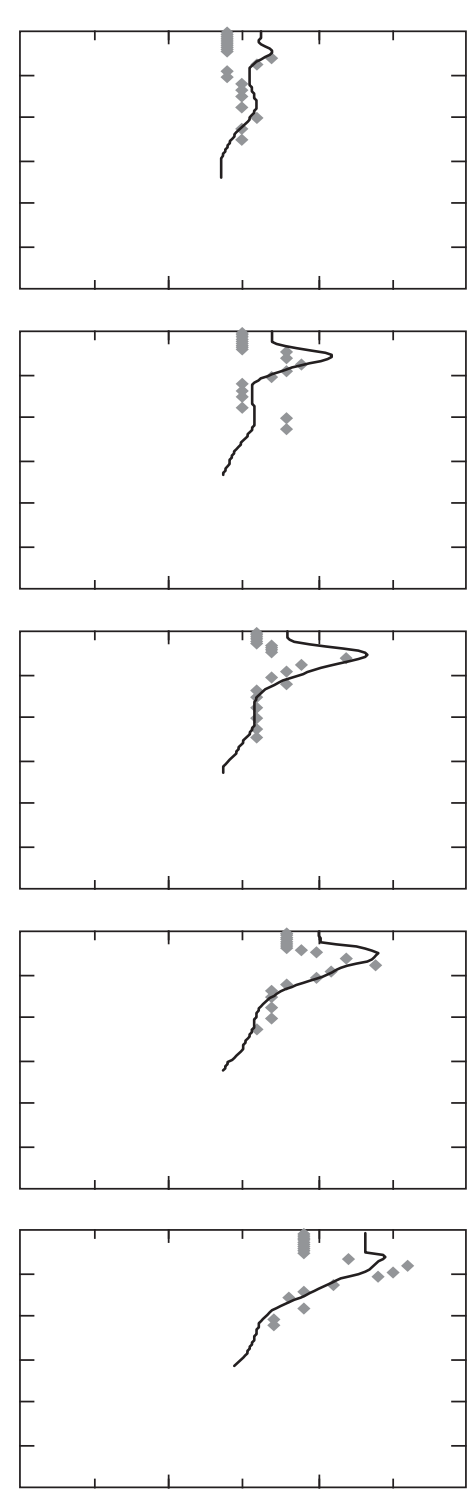

MONGOLD
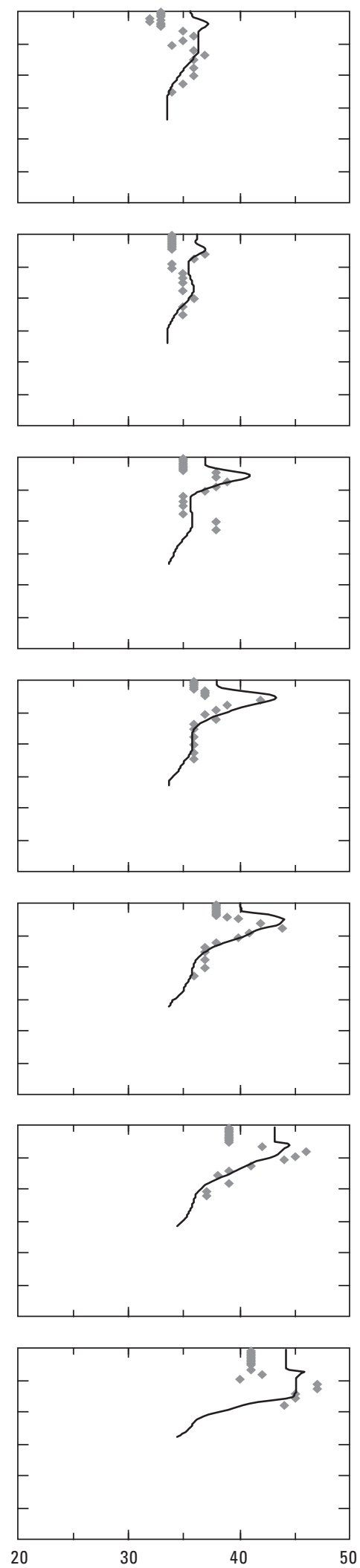

SPECIFIC CONDUCTANCE, IN MICROSIEMENS PER CENTIMETER

Figure 13.-Continued. 
22 Modeling Hydrodynamics, Water Temperature, and Suspended Sediment in Detroit Lake, Oregon

2006

January 13
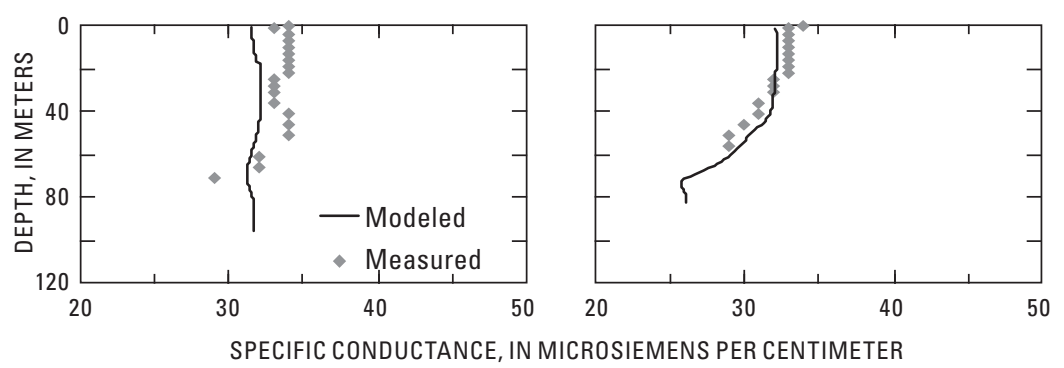

BLOWOUT$$
\text { 西 }
$$

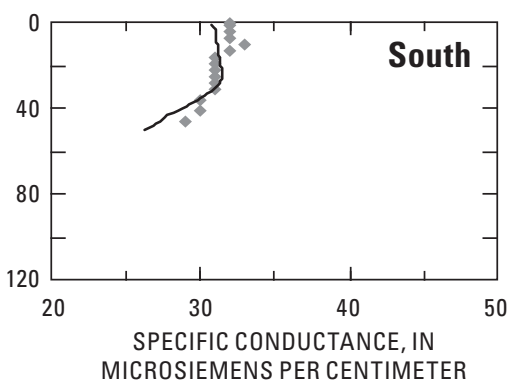

Figure 14. Measured specific conductance profiles at four locations in Detroit Lake, Oregon, compared to modeled specific conductance (derived from total dissolved solids) at the same location and time in 2006. Model output extends to the bottom of the lake at each site.

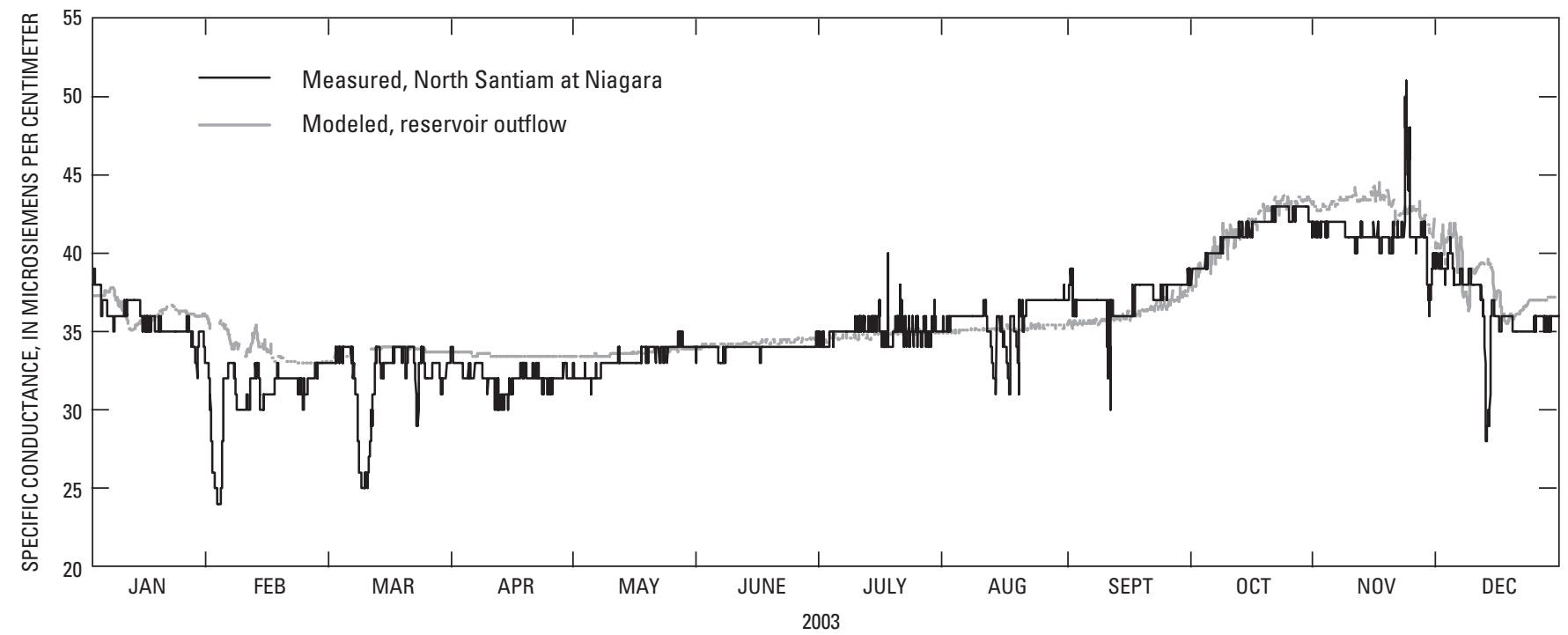

Figure 15. Modeled specific conductance (converted from modeled total dissolved solids) in the Detroit Lake, Oregon, reservoir outflow compared to measured specific conductance in the North Santiam River at Niagara, 6 km downstream, in 2003. 
Calculation of goodness-of-fit statistics for measured specific conductance and specific conductance converted from modeled TDS for the three modeled time periods (2002, 2003, 2005-06) produced MEs between -0.15 and $1.49 \mu \mathrm{S} / \mathrm{cm}, \mathrm{MAEs}$ between 1.31 and $2.11 \mu \mathrm{S} / \mathrm{cm}$, and RMSEs between 2.42 and $3.13 \mu \mathrm{S} / \mathrm{cm}$ (table 3). Sources of error include the estimation of TDS in ungaged inflows and any nonconservative reactions that affect dissolved solids. Overall, though, errors in simulating specific conductance are approximately 5 to 10 percent of measured values in the lake (range of about 27 to $47 \mu \mathrm{S} / \mathrm{cm}$ ).

\section{Suspended Sediment}

Sediment suspended in the water column is a natural component of lakes and rivers. Excessive concentrations of suspended sediment, however, can impair certain uses. For example, high sediment loads can bury spawning gravels and reduce light penetration into the water column, making it more difficult for fish to find prey. Sediment in water used for drinking water supply can cause taste and odor problems and impair the efficiency and operation of treatment systems. High concentrations of suspended sediment that settle and deposit in a reservoir can reduce the volume available for water storage. Suspended sediment also can contribute surfaces for ion exchange and adsorption between dissolved and particulate phases of various constituents (Horne and Goldman, 1994), and thus act as a storage and transport medium for nutrients, organic contaminants, and trace metals. Suspended sediment concentrations are controlled by factors such as hydrodynamics, sources, density, and settling rates.

In the model calibration process, the settling rates for the two simulated sediment-size groups were adjusted until the model results and the measured data compared well. In the final Detroit Lake model, suspended sand and silt, particles larger than $2 \mu \mathrm{m}$, was given a settling rate of $21.0 \mathrm{~m} / \mathrm{d}$, and suspended clay, particles smaller than $2 \mu \mathrm{m}$, was given a settling rate of $0.6 \mathrm{~m} / \mathrm{d}$. For comparison, Stokes' Law may be used to estimate the settling velocities of spherical particles in water (Lide, 2006):

$$
v=\frac{g \cdot d^{2} \cdot\left(\rho_{p}-\rho_{w}\right)}{18 \cdot \mu}
$$

where:

$v$ is setting velocity, in $\mathrm{cm} / \mathrm{s}$,

$g$ is gravitational acceleration constant, $981 \mathrm{~cm} / \mathrm{s}^{2}$,

$d$ is particle diameter, in $\mathrm{cm}$,

$\rho_{p}$ is particle density, in $\mathrm{g} / \mathrm{cm}^{3}$,

$\rho_{w}$ is water density, in $\mathrm{g} / \mathrm{cm}^{3}, 0.99823$ at $20^{\circ} \mathrm{C}$, and

$\mu$ is viscosity of water $[0.01002(\mathrm{~g} / \mathrm{cm}) / \mathrm{s}]$ at $20^{\circ} \mathrm{C}$.

The Stokes' Law settling rates are idealized, assuming spherical particles and homogeneous particle density, particle size, and water temperature. With a particle density of $2.7 \mathrm{~g} / \mathrm{cm}^{3}$, a typical value for silicate minerals including clays and quartz (sand), a particle with a diameter of $2 \mu \mathrm{m}$ would have an ideal settling velocity in pure water of $0.00037 \mathrm{~cm} / \mathrm{s}$, or $0.32 \mathrm{~m} / \mathrm{d}$ at $20^{\circ} \mathrm{C}$. Larger particles with a $62 \mu \mathrm{m}$ diameter would settle at $307 \mathrm{~m} / \mathrm{d}$ at $20^{\circ} \mathrm{C}$, and smaller particles of $1 \mu \mathrm{m}$ would settle at $0.08 \mathrm{~m} / \mathrm{d}$ at $20^{\circ} \mathrm{C}$. Under colder conditions, the density of water would change only slightly, whereas the viscosity of water would increase, but only by a factor of 1.6 from $20^{\circ} \mathrm{C}$ to $4^{\circ} \mathrm{C}$. In nature, these idealized conditions do not hold, so rates calculated with Stokes' Law are not expected to be exactly the same as rates in Detroit Lake. However, comparing modeled rates for Detroit Lake to ideal Stokes' Law rates is a useful comparison, and both are fairly similar.

In the modeled time periods, most of the suspended sediment entered the reservoir during winter and spring storms (fig. 16). The suspended sand and silt settled relatively quickly, whereas the clay-sized sediment remained in suspension for longer periods. In summer and autumn, suspended sediment concentrations were relatively low $(<0.5 \mathrm{mg} / \mathrm{L})$ in the lake.

This pattern of sediment input and settling was similar in all modeled time periods (figs. 17, $\underline{18}$, and $\underline{19}$ ). There was some variability between different profile locations in the lake, particularly during storms. Heterogeneity of suspended sediment concentrations is expected in the lake, with variations in inputs between tributaries, and different distances from tributary inputs, combined with settling processes in the reservoir. 


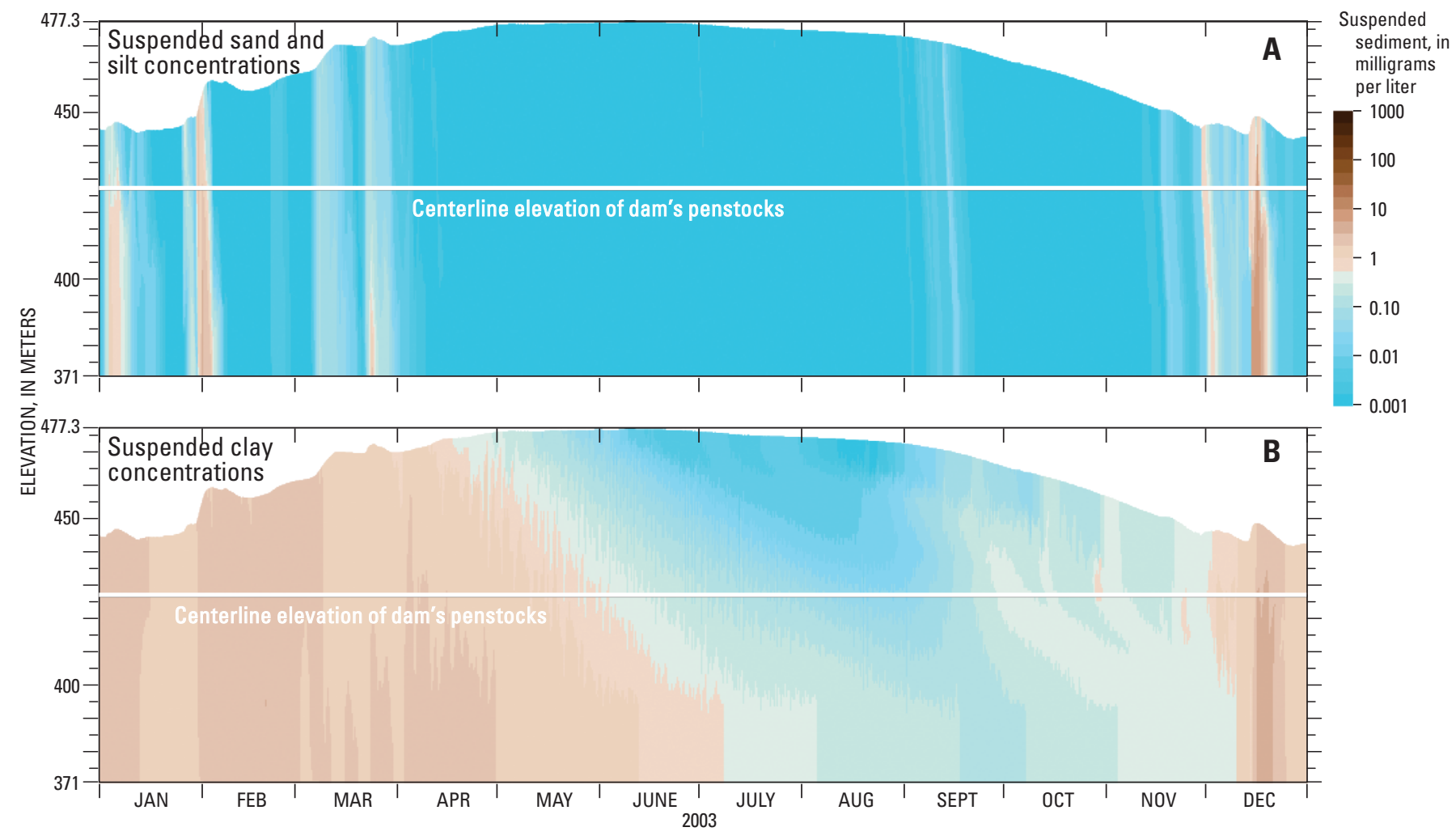

Figure 16. Modeled profiles of suspended sediment concentrations in Detroit Lake, Oregon, near the dam as a function of time during 2003.

For some of the lake profiles in summer, suspended sediment concentrations were elevated at the lake surface, but the model did not simulate these elevated concentrations. This was due to the fact that algae blooms occur in the lake; they contribute to measurements of suspended sediment and turbidity, but the model does not simulate algae. Evidence for algal blooms in Detroit Lake during the summers of 2002 and 2003 was based in part on concurrent dissolved oxygen and $\mathrm{pH}$ data from the vertical profiles. Elevated surface $\mathrm{pH}$, dissolved oxygen supersaturation, and elevated turbidity due to an algal bloom occurred on June 12, 2002, for example, (fig. 20). Algae were not simulated by the Detroit Lake model due to the lack of data necessary to model algae; simulating algal succession in Detroit Lake was beyond the scope of this project. Sampling of algae in Detroit Lake at the main lake sampling sites between June 19, 2003, and September 10, 2003, corroborated the chemical evidence of summertime 
algal blooms. In those samplings, the dominant algal species were Rhodomonas minuta, Chromulina sp., Asterionella formosa, Anabaena flos-aquae, Cryptomonas erosa, Synedra radians, and Fragilaria crotonensis, in order of relative density. Additional information and data from these samples is available online (see section, "Supplemental Material").

The highest suspended sediment concentrations in the outflow occurred during winter and spring, with low concentrations during summer; this reflects the patterns of suspended sediment concentrations in the lake (shown as turbidity in fig. 21A). Turbidity data from the North Santiam River at Niagara were more variable than those in the reservoir outflow, owing to the fact that the reservoir buffers the effects of storm flows, and the fact that several undammed tributaries enter the river between Detroit Dam and the monitor at Niagara. Suspended sand- and silt-sized sediment typically was released from the lake only during storm events, whereas varying amounts of suspended clay were released throughout most of the year (fig. $21 B$ ).

Comparing measured and modeled total suspended sediment concentrations for 2002 and 2003 produced MEs of -0.61 and $-0.45 \mathrm{mg} / \mathrm{L}$, MAEs of 0.91 and $0.80 \mathrm{mg} / \mathrm{L}$, and RMSEs of 1.16 and $1.04 \mathrm{mg} / \mathrm{L}$, respectively (table 3).
Calculating goodness-of-fit statistics for the January 2006 profiles produced an ME of $-1.68 \mathrm{mg} / \mathrm{L}$, MAE of $3.34 \mathrm{mg} / \mathrm{L}$, and RMSE of $3.92 \mathrm{mg} / \mathrm{L}$ (table 3). The highest error occurred during the storm event, when inflows were large, and the estimated suspended sediment loads from ungaged inflows were most uncertain. Goodness-of-fit statistics using the measured turbidity profiles converted to suspended sediment, rather than the sampled suspended sediment concentrations, were slightly better (table 3). Measured and modeled suspended sediment concentrations on days, locations, and depths where algae blooms occurred were not included in the error statistic calculations.

Sources of error include the estimation of inflows and the representation of suspended sediment with only two size groups. The version of CE-QUAL-W2 used for the Detroit Lake model also did not include algorithms to quantify the effects of sediment resuspension and scour. In the model, the mass of deposited sediment cannot reenter the water column or be moved upstream or downstream. More recent versions of CE-QUAL-W2 do include an algorithm for wind resuspension of sediment, but the effects of scour are not yet included in any version of the model. 
2002

April 25

June 12

July 18

May 16

June 26
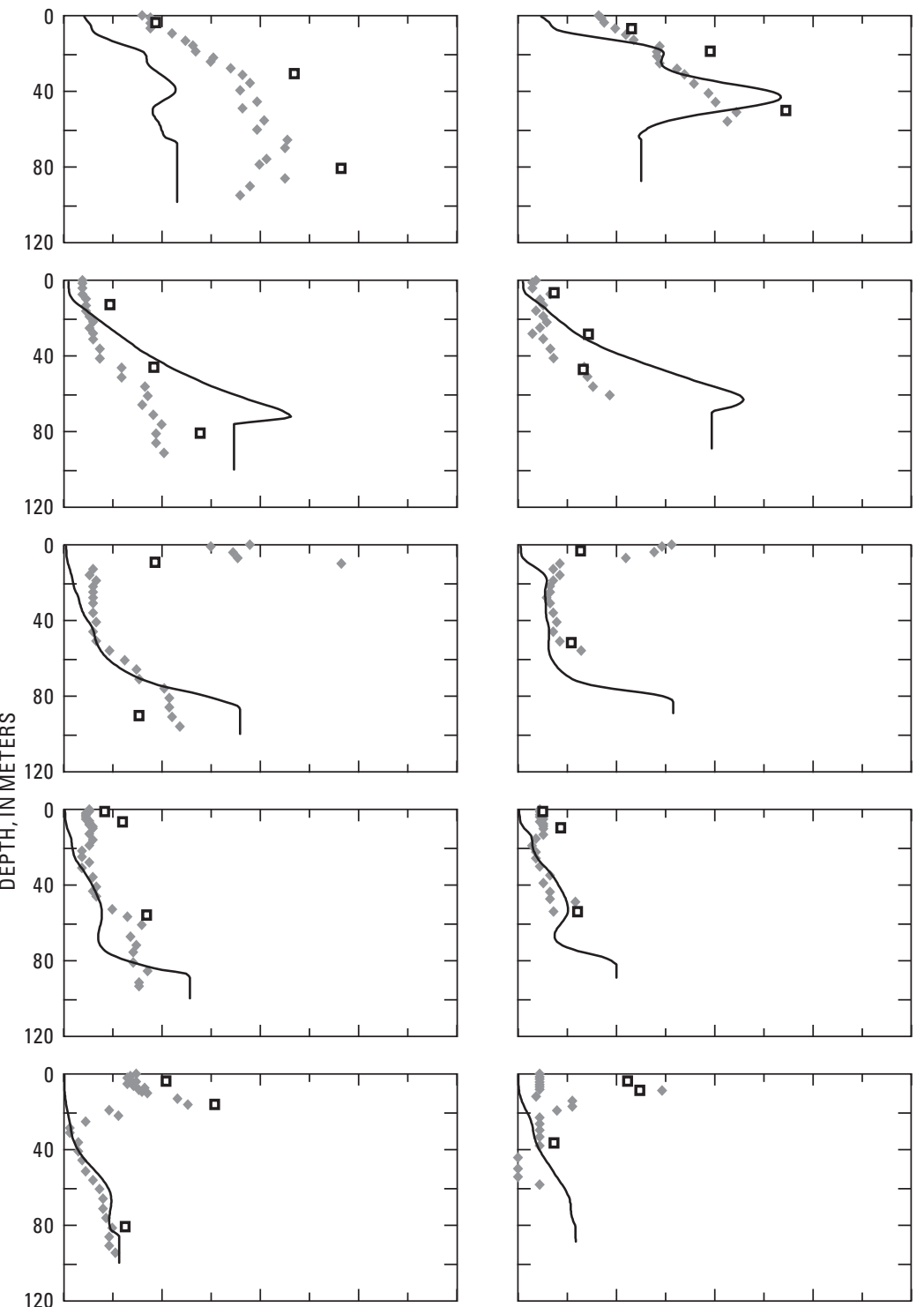

August 6

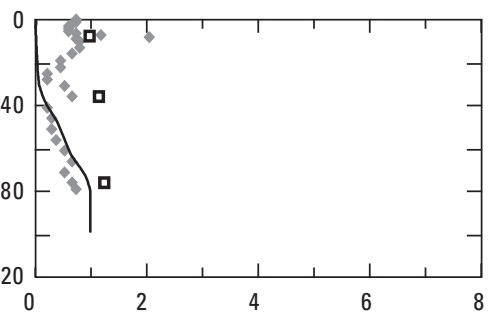

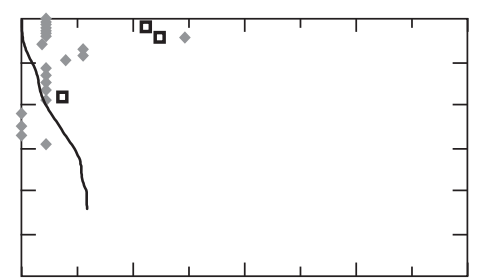

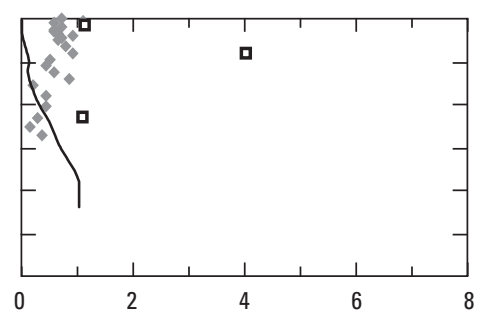

MONGOLD
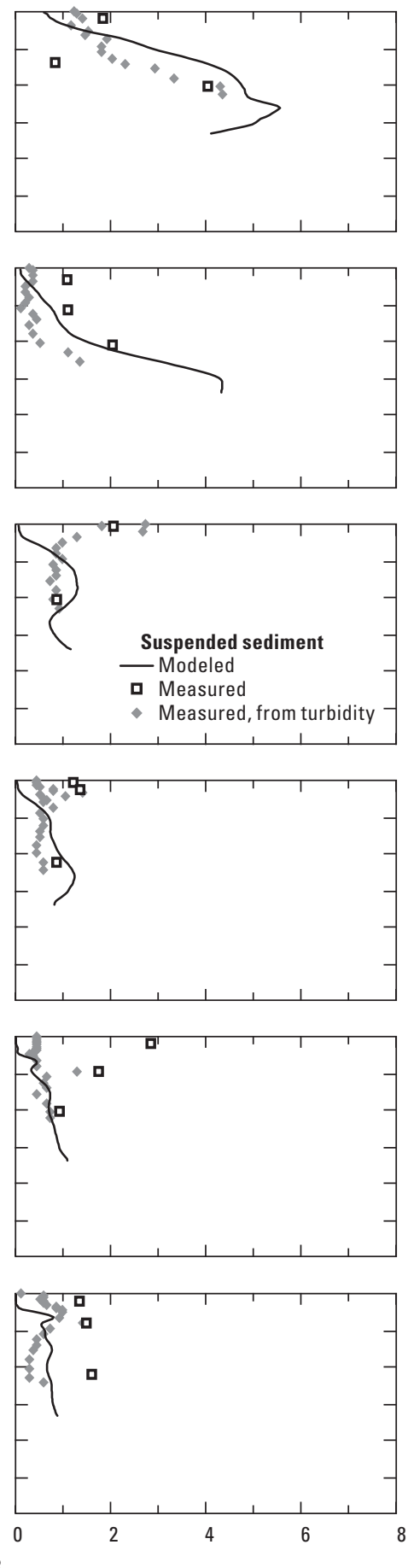

Figure 17. Total suspended sediment concentration profiles, both measured and calculated from turbidity, at three locations in Detroit Lake, Oregon, compared to modeled total suspended sediment concentration at the same location and time in 2002. Model output extends to the bottom of the lake at each site. 
KINNEY

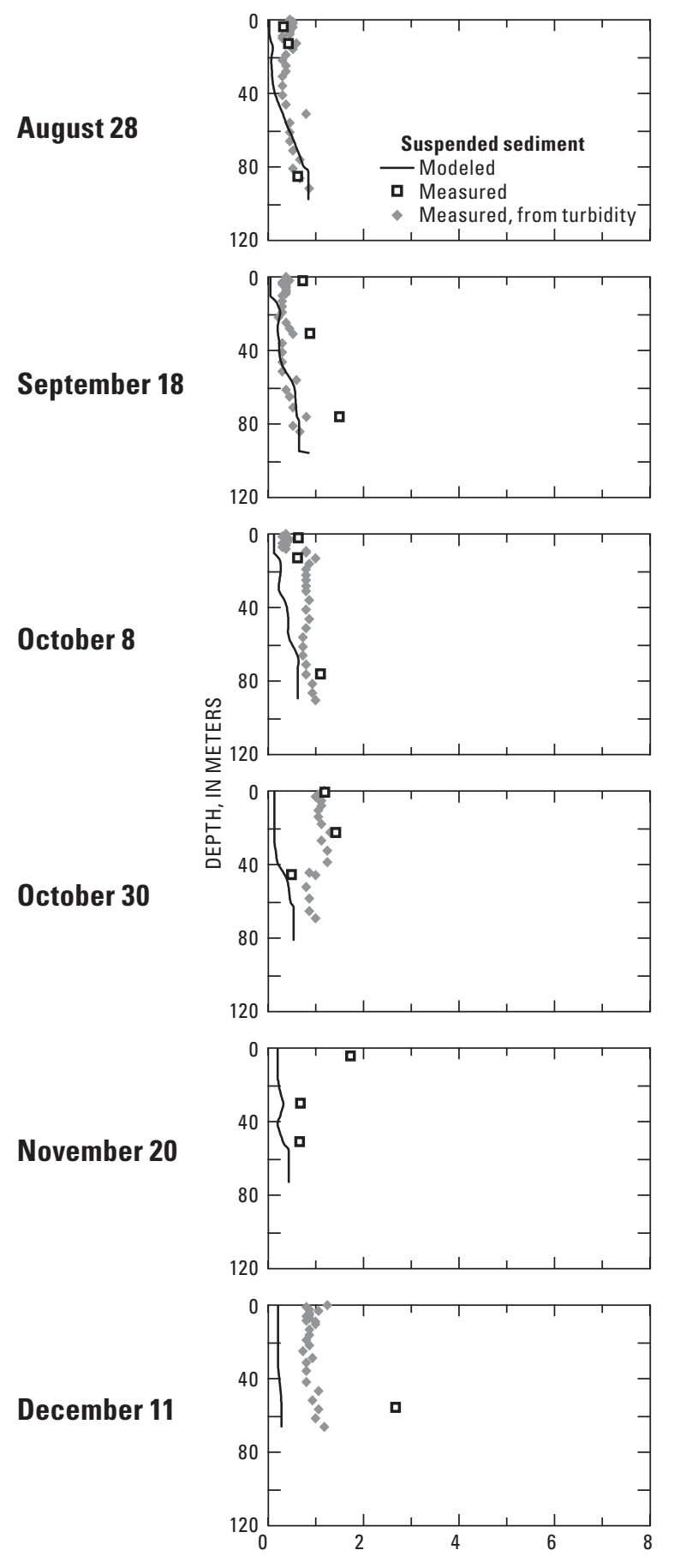

BLOWOUT
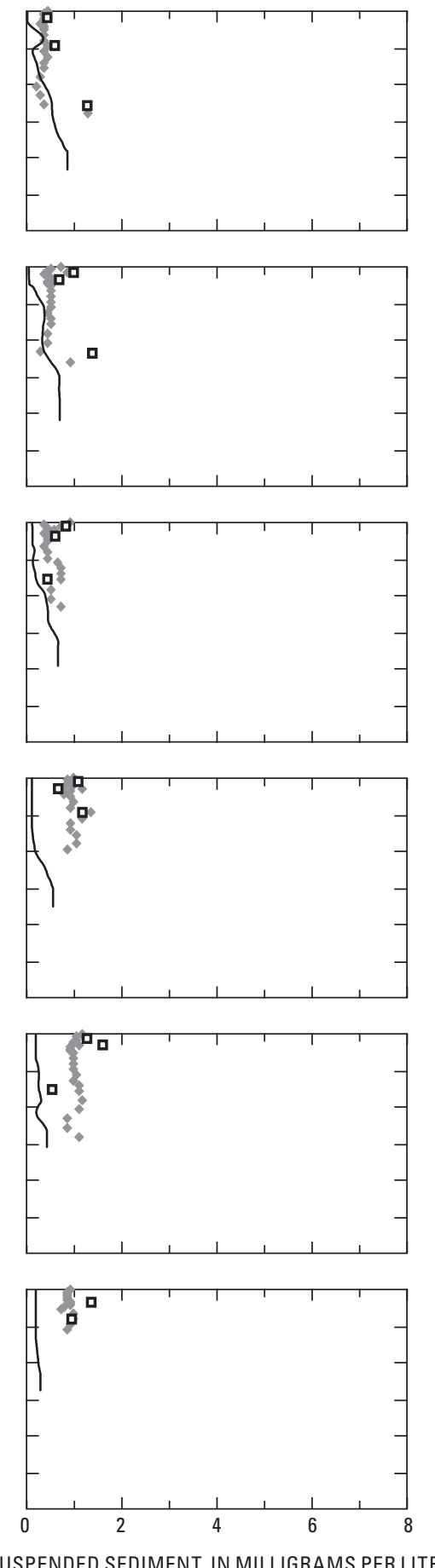

MONGOLD
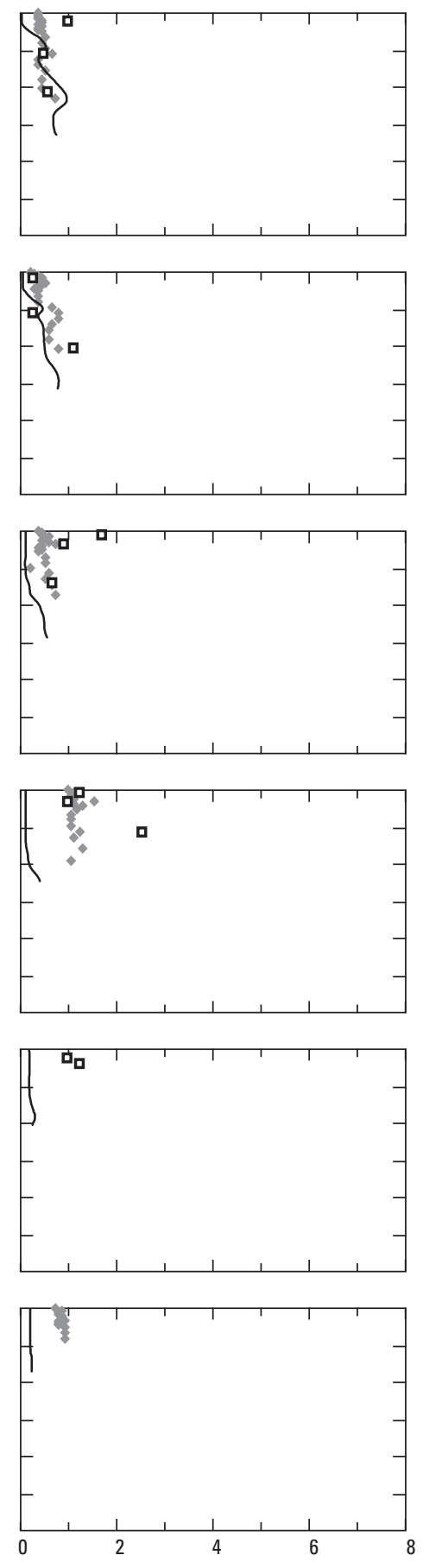

Figure 17.-Continued. 
2003

KINNEY
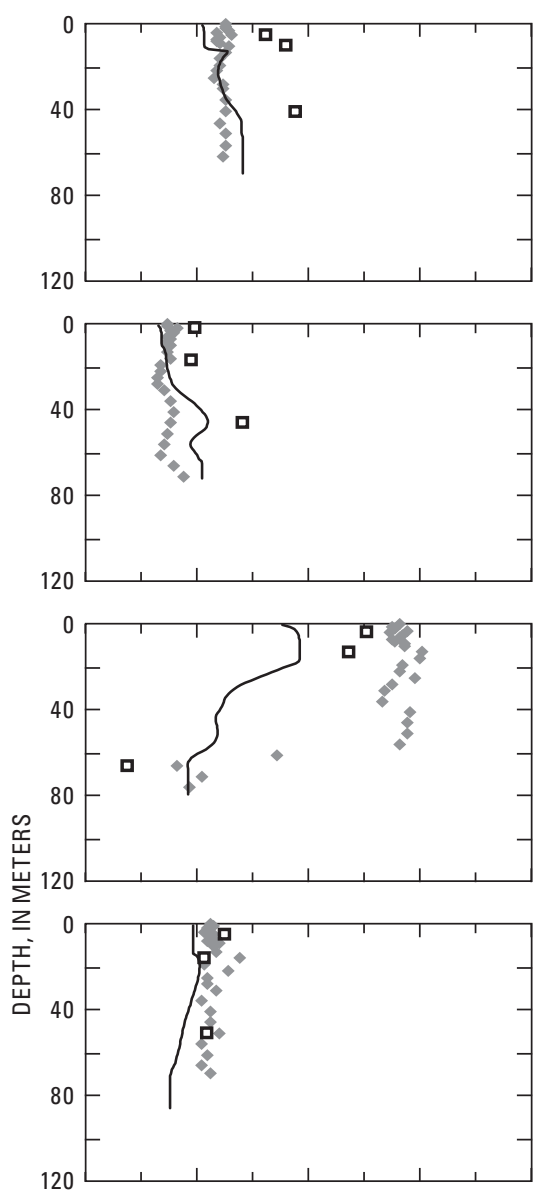

February 6

March 5

April 17

May 8
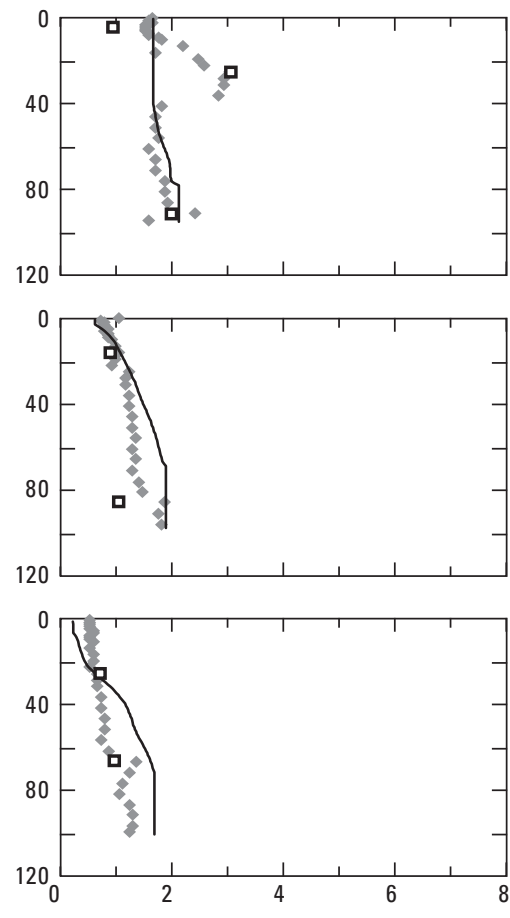

BLOWOUT
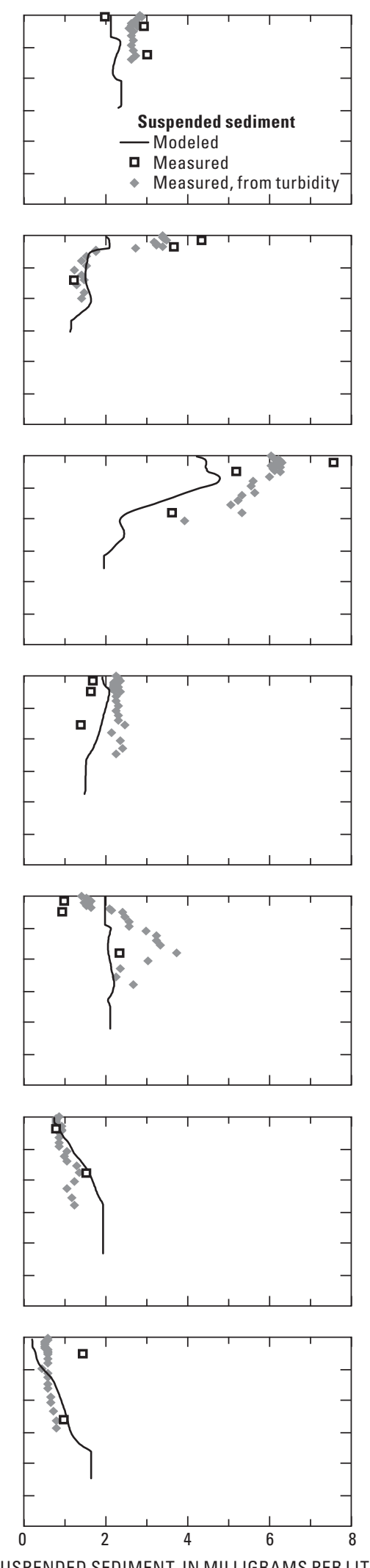

MONGOLD
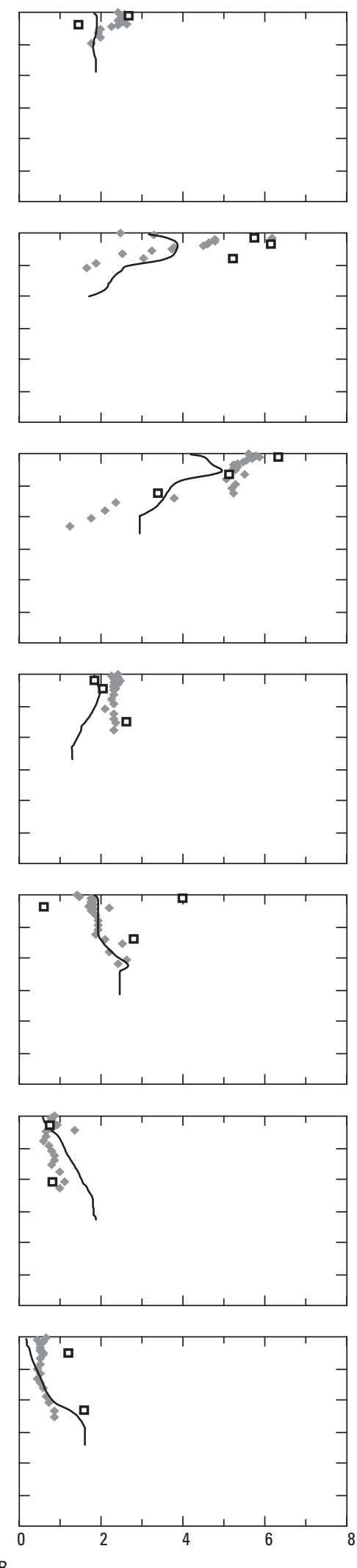

Figure 18. Total suspended sediment concentration profiles, both measured and calculated from turbidity, at three locations in Detroit Lake, Oregon, compared to modeled total suspended sediment concentration at the same location and time in 2003. Model output extends to the bottom of the lake at each site. 


\section{KINNEY}

May 28

July 10

July 30

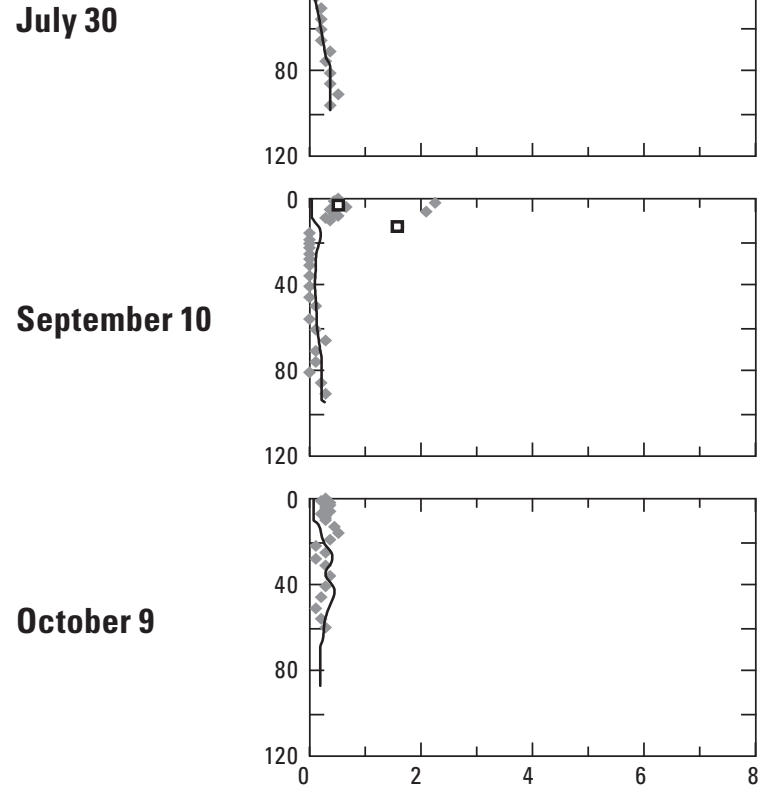

BLOWOUT
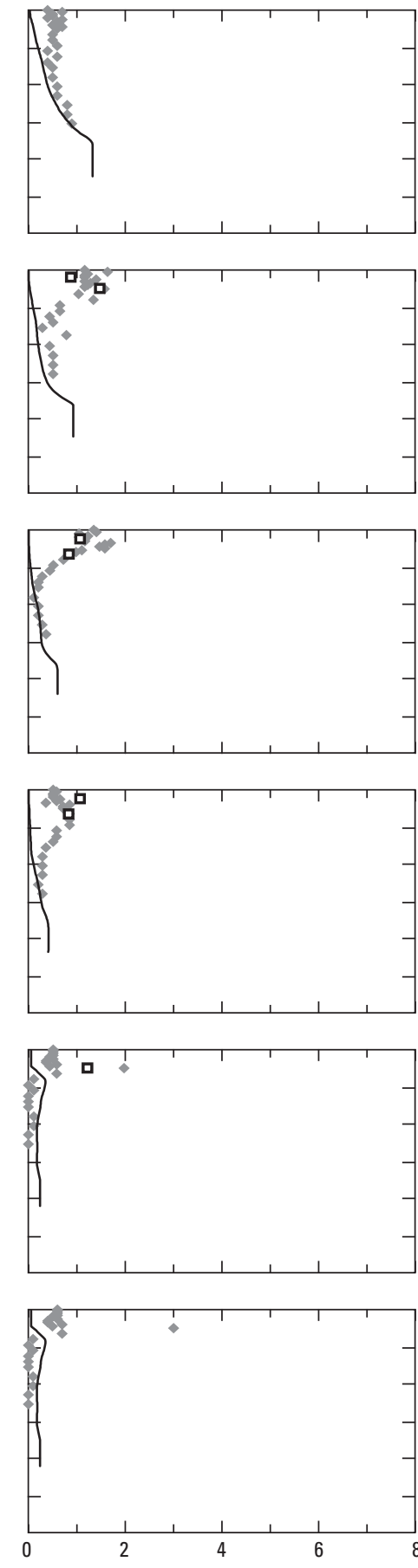

SUSPENDED SEDIMENT, IN MILLIGRAMS PER LITER
MONGOLD
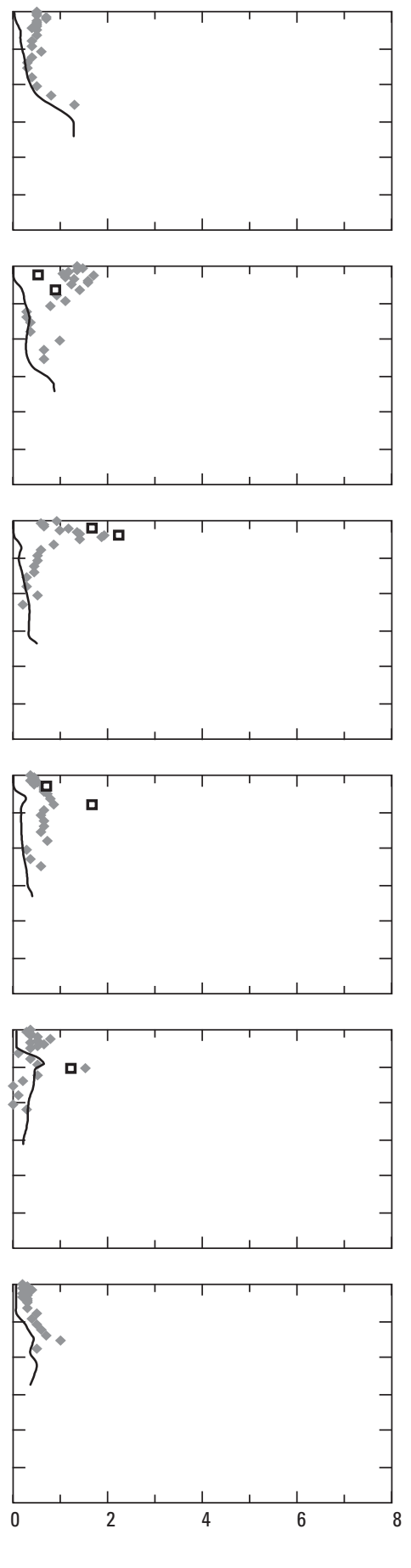

Figure 18.-Continued. 
KINNEY

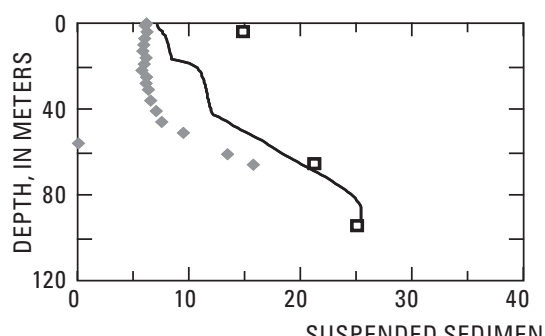

BLOWOUT

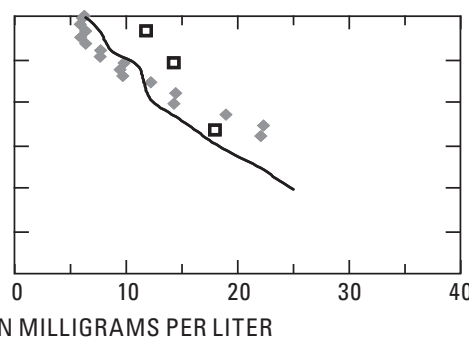

MONGOLD
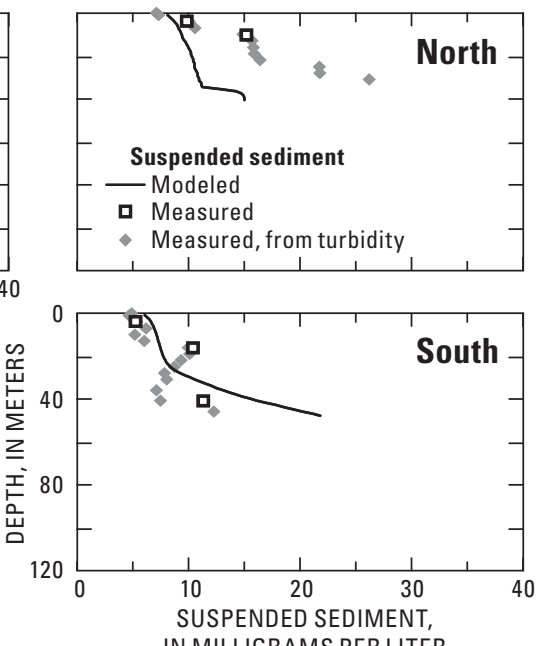

Figure 19. Total suspended sediment concentration profiles, both measured and calculated from turbidity, at four locations in Detroit Lake, Oregon, compared to modeled total suspended sediment concentration at the same location and time in 2006. Model output extends to the bottom of the lake at each site.
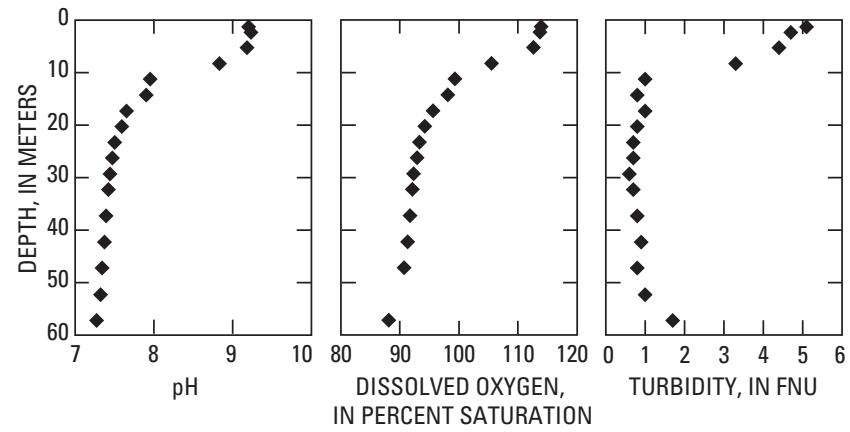

Figure 20. Chemical ( $\mathrm{pH}$ and dissolved oxygen) and physical (surface turbidity) evidence of an algal bloom at the Blowout lake monitoring site, Detroit Lake, Oregon, June 12, 2002. 

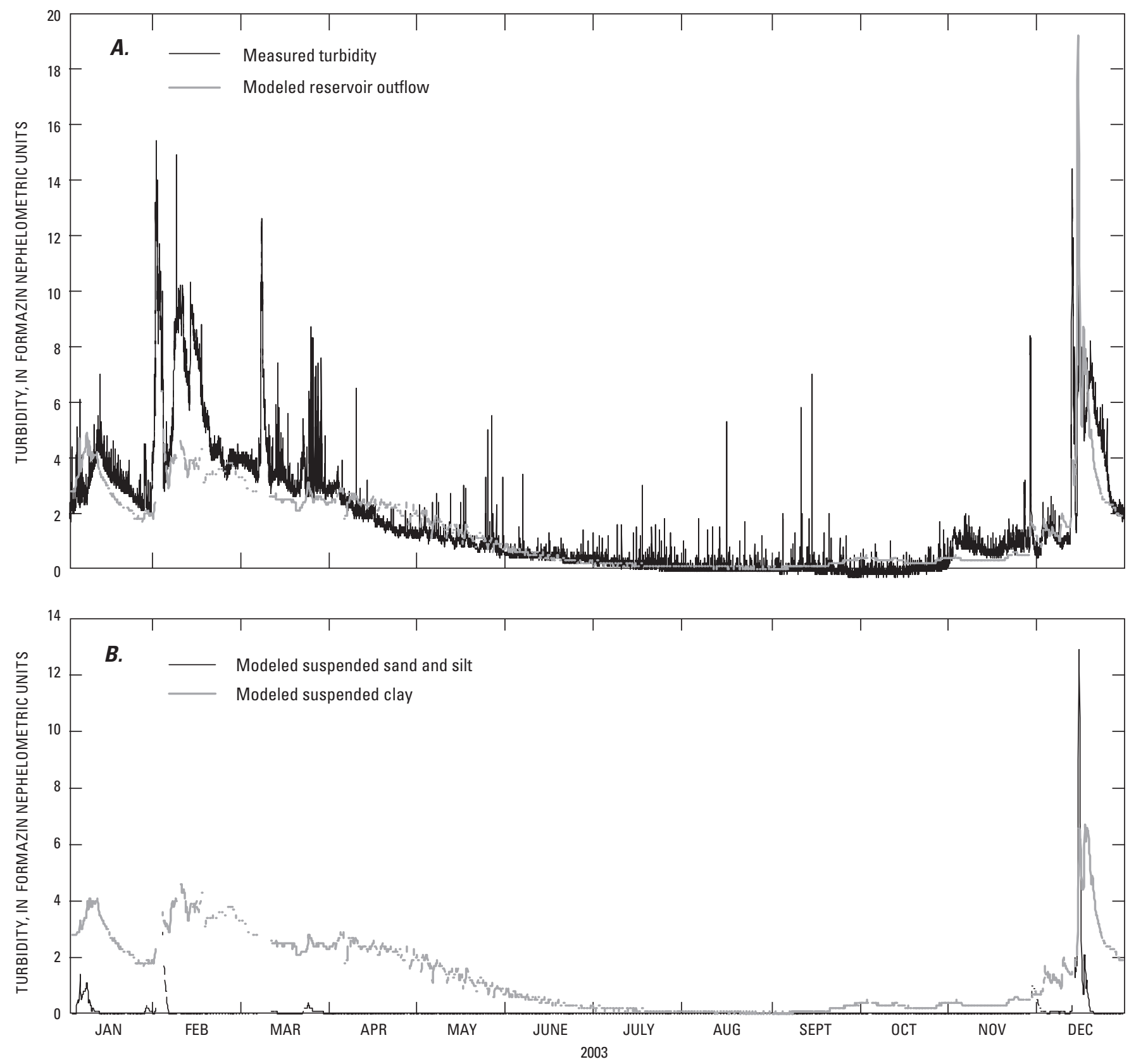

Figure 21. Modeled total suspended sediment concentration in reservoir outflow, converted to turbidity and modeled distribution of two sediment size groups, Detroit Lake, Oregon, 2003: $(A)$ compared to measured turbidity in the North Santiam River at Niagara, $6 \mathrm{~km}$ downstream, in 2003 and $(B)$ showing the distribution between the two sediment size groups. 


\section{Model Sensitivity}

The model's wind sheltering coefficient, suspended sediment settling rates, suspended sediment light extinction factor, and bottom sediment temperature were all individually increased and decreased by 20 percent in separate model runs to determine the effect of changing that parameter on the model output. The sensitivity of modeled water temperature, suspended sand and silt concentrations, and suspended clay concentrations to these parameters were examined in the lake and in the lake outflow for 2003. In addition, a qualitative sense of model sensitivity was gained in the model calibration process.

Varying these model parameters by 20 percent did not have large effects on in-lake or outflow average water temperatures (table 4). Of the parameter group, only changes in the wind sheltering coefficient (which modifies wind speed) and the temperature of bottom sediments had any effect at all, and these effects were localized in the water column. Wind did affect the shape of the water temperature profile near the lake surface; higher winds led to more mixing, a deeper mixed surface layer, and less vertical variability in nearsurface water temperatures. A 20 percent change in bottom sediment temperature had only a small effect on lake water temperatures, and this effect was greatest for water near the bottom of the lake.
Varying the suspended sand and silt and suspended clay settling rates by 20 percent had a large effect on suspended sediment concentrations in the lake (table 4). Decreasing the suspended sediment settling rates (making sediment settle more slowly), as expected, led to increased average annual concentrations of suspended sediment in the lake and in the outflow. In contrast, increasing the suspended sediment settling rates (sediment settles faster) decreased suspended sediment concentrations both in the lake and the reservoir outflow. These effects were greatest for suspended sand and silt. Smaller effects on suspended sediment concentrations were caused by varying the wind sheltering coefficient and the bottom sediment temperature by 20 percent. Increasing the wind sheltering coefficient increases the wind shear at the lake's surface and leads to more wind mixing, keeping the sediment suspended longer and leading to a small increase in the simulated suspended sediment concentration. Varying the light extinction factor for suspended sediment had no effect on suspended sediment concentrations in the lake. This light extinction factor is only relevant to the surface photic zone, a relatively small portion of the lake volume. TDS concentrations had no change in any of these sensitivity runs.

Table 4. Results from sensitivity testing showing the effect of changing a particular input parameter on annual average temperature, suspended sand and silt, and suspended clay in the whole lake and in the lake outflow for 2003.

\begin{tabular}{l|c|c|c|c|c|c|c}
\hline \multicolumn{2}{c|}{ Input } & \multicolumn{8}{c}{ Output } \\
\hline \multirow{2}{*}{ Parameter } & \multirow{2}{*}{$\begin{array}{c}\text { Percent } \\
\text { change }\end{array}$} & \multicolumn{2}{|c|}{ WHOLE LAKE, percent change } & \multicolumn{3}{c}{ OUTFLOW, percent change } \\
\cline { 3 - 8 } & & Temperature & $\begin{array}{c}\text { Suspended } \\
\text { sand and silt }\end{array}$ & $\begin{array}{c}\text { Suspended } \\
\text { clay }\end{array}$ & Temperature & $\begin{array}{c}\text { Suspended } \\
\text { sand and silt }\end{array}$ & $\begin{array}{c}\text { Suspended } \\
\text { clay }\end{array}$ \\
\hline Wind sheltering coefficient & -20 & -1 & -3 & -1 & -1 & +2 & 0 \\
& +20 & +1 & +5 & +1 & +1 & -2 & 0 \\
Temperature of bottom sediments & -20 & -1 & 0 & 0 & -1 & -3 & 0 \\
& +20 & +1 & 0 & 0 & +1 & +6 & 0 \\
Light extinction factor for & -20 & 0 & 0 & 0 & 0 & 0 & 0 \\
suspended sediments & +20 & 0 & 0 & 0 & 0 & 0 & 0 \\
Suspended sediment settling rate & -20 & 0 & +33 & +12 & 0 & +65 & +10 \\
& +20 & 0 & -21 & -10 & 0 & -35 & -8 \\
\hline
\end{tabular}




\section{Model Applications}

The calibrated Detroit Lake model was used to examine several scenarios. Results from the following applications are presented herein:

- An examination of the sediment entering and exiting the reservoir, including estimates of sediment trap efficiency and the volume of sediment deposited,

- An investigation of the sources of sediment to the reservoir outflow, and

- A demonstration of the effect of a hypothetical selective withdrawal device on water temperatures released from Detroit Dam.

\section{Characteristics of Sediment Inflows, Outflows, and Deposits}

Determining the amount of sediment that exits the reservoir and the amount of sediment that is retained by the reservoir is important in determining the depletion of reservoir storage, making decisions on reservoir operation, and assessing downstream effects. Reservoir sediment trap efficiency is defined as the percentage of sediment input retained by the lake. Methods such as the Brune ratio, calculated from ratios of reservoir capacity to annual water inflow, have been used to calculate this quantity (Brune, 1953; Snyder and others, 2004). However, calculations that use a constant reservoir capacity or residence time are not recommended for reservoirs such as Detroit Lake that vary greatly in surface elevation and volume over the course of a year. That change in volume also changes the residence time and the corresponding amount of time available for suspended sediment to settle (Ambers, 2001). The calibrated Detroit Lake model keeps track of suspended sediment deposition, allowing trap efficiency to be calculated directly with the model. In calendar year 2002, the trap efficiency of Detroit Lake was calculated to be 93 percent, in 2003 it was calculated as 90 percent, and during the 2005-06 storms, it was calculated as 94 percent (table 5). Because of residence time, the sediment that exits the reservoir in one year may have entered the reservoir in a previous year; similarly, suspended sediment that enters the reservoir in 2002 may not exit until a future year. Most of the suspended sediment that enters the lake is trapped; only 10 percent or less exited in the modeled time periods.

Table 5. Modeled sand and silt, clay, and total sediment entering, exiting, and deposited in Detroit Lake for the three modeled time periods.

[Volumes are estimated assuming a sediment bulk density of $1.89 \mathrm{~g} / \mathrm{cm}^{3}$. Sediment deposited in the reservoir is calculated by subtracting outflow from inflow, and is corrected by adding the difference between the initial and final suspended sediment mass in the lake water column. 1 metric ton $=1,000 \mathrm{kilograms}]$

\begin{tabular}{|c|c|c|c|c|c|c|c|c|c|}
\hline & \multicolumn{3}{|c|}{ Jan. 1 - Dec. 31, 2002} & \multicolumn{3}{|c|}{ Jan. 1 - Dec. 31, 2003} & \multicolumn{3}{|c|}{ Dec. 1, 2005 - Feb. 1, 2006} \\
\hline \multicolumn{10}{|c|}{ Inflow sediment } \\
\hline Sediment mass (metric tons) & 24,740 & 4,250 & 28,990 & 20,370 & 4,180 & 24,550 & 65,180 & 5,780 & 70,960 \\
\hline Sediment volume (cubic meters) & 13,090 & 2,250 & 15,340 & 10,780 & 2,210 & 12,990 & 34,490 & 3,060 & 37,550 \\
\hline \multicolumn{10}{|c|}{ Outflow sediment } \\
\hline Sediment volume (cubic meters) & 100 & 1,050 & 1,150 & 90 & 1,160 & 1,250 & 360 & 1,970 & 2,330 \\
\hline \multicolumn{10}{|c|}{ Difference between initial and final (initial - final) suspended sediment in water column } \\
\hline Sediment mass (metric tons) & -70 & 290 & 220 & 0 & 160 & 160 & -60 & -540 & -600 \\
\hline Sediment volume (cubic meters) & -40 & 150 & 110 & 0 & 80 & 80 & -30 & -290 & -320 \\
\hline \multicolumn{10}{|c|}{ Sediment deposited in Detroit Lake } \\
\hline Percent trapped & 99 & 56 & 93 & 99 & 50 & 90 & 99 & 29 & 94 \\
\hline Percent exported & 1 & 44 & 7 & 1 & 50 & 10 & 1 & 71 & 6 \\
\hline
\end{tabular}


If sediment grains with a $2.7 \mathrm{~g} / \mathrm{cm}^{3}$ density are assumed to have a 30 percent pore space upon deposition, leading to sediment deposits with $1.89 \mathrm{~g} / \mathrm{cm}^{3}$ dry bulk density, then approximately $14,300 \mathrm{~m}^{3}$ (11.6 acre-ft) of sediment was deposited in the lake in calendar year 2002, $11,820 \mathrm{~m}^{3}$ (9.6 acre-ft) in 2003, and 34,900 $\mathrm{m}^{3}$ (28.3 acre-ft) from December 1, 2005, to February 1, 2006. The mass of sediment entering and deposited in the reservoir in the 2-month period during the 2005-06 storms was more than double the mass of sediment deposited in the entire calendar years of either 2002 or 2003, emphasizing the importance of storm flows to reservoir sediment budgets. These volumes of sediment are all less than 0.01 percent of Detroit Lake's full pool volume of 561 million $\mathrm{m}^{3}$ (455,000 acre-ft), indicating that Detroit Lake is not likely to fill up anytime soon. The actual density of the deposited sediment can vary depending on factors such as composition, age, and wetting and drying, which can lead to compaction (Vanoni, 1975).
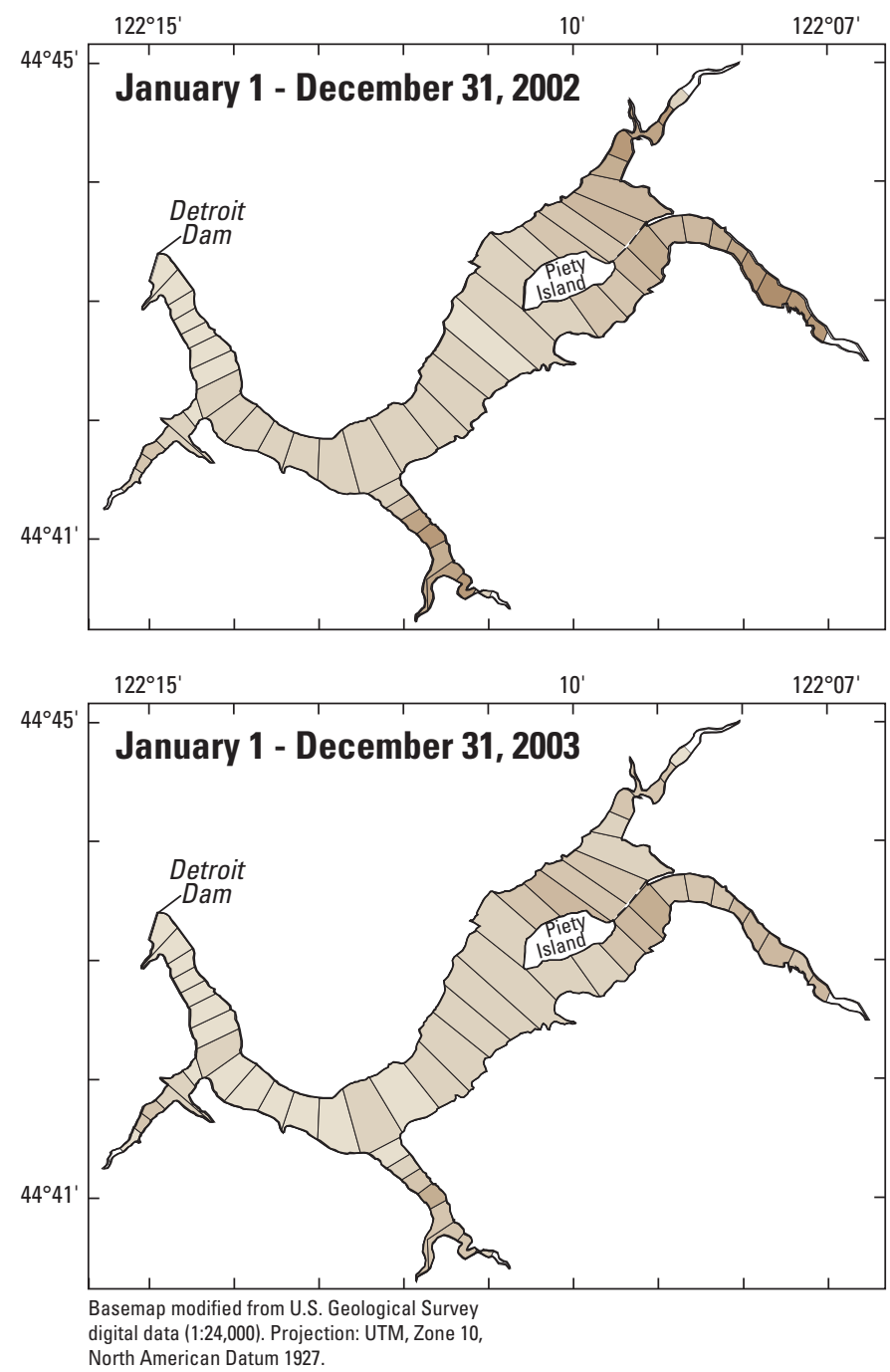

The model results indicated that most of the sediment was deposited in the upper reaches of the reservoir and areas near major inflows (fig. 22). The velocity of the inflows, and their sediment carrying capacity, decreases substantially as they enter the pooled reservoir. The predicted deposition rates can be substantial during a large storm inflow. Areaaveraged deposition rates in the North Santiam arm of the lake during the 2005-06 storms, for example, were simulated to be as high as $20 \mathrm{~kg} / \mathrm{m}^{2}$ for the 2-month simulation period (fig. 22). Assuming a sediment bulk density of $1.89 \mathrm{~g} / \mathrm{cm}^{3}$, this deposition could have reached an average thickness of $1.06 \mathrm{~cm}$. This is an area-averaged value; some areas would have less deposition, and others would have more. Deposited sediment can be resuspended and redistributed during other storm events, particularly if the stage of the lake decreases enough to convert that area from a pooled reach to a riverine reach. The Detroit Lake model currently does not include

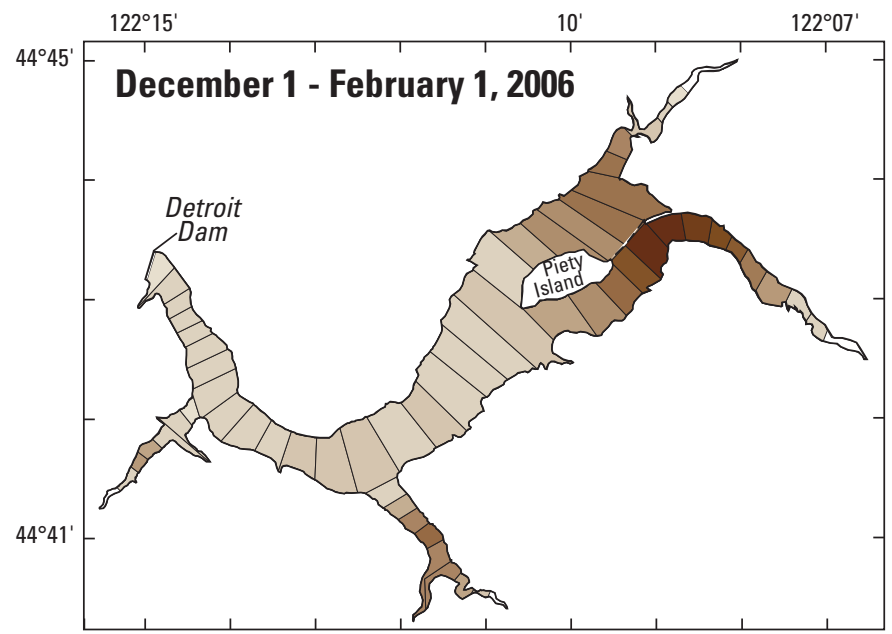

EXPLANATION

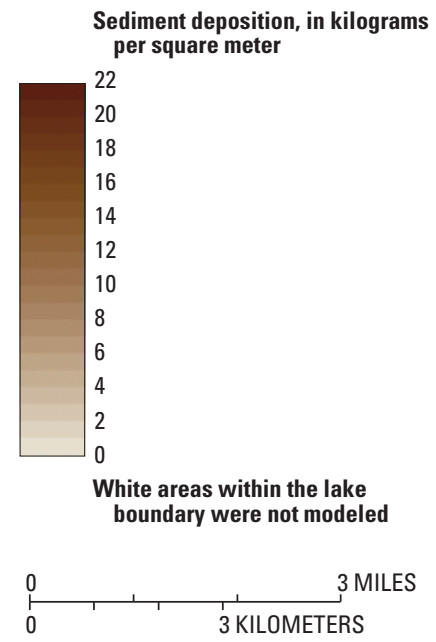

Figure 22. Modeled spatial distribution of suspended sediment deposition in Detroit Lake, Oregon, for calendar years 2002, 2003, and the period between December 1, 2005 and February 1, 2006. The deposition plotted in these figures is output for each model segment and ranges from 0.6 to $20.2 \mathrm{~kg} / \mathrm{m}^{2}$. 
algorithms to fully simulate the effects of scour and sediment resuspension, which may be important processes that redistribute sediment further into the reservoir.

The calibrated model also was used to investigate the size of the sediment flowing into and exiting the reservoir. In 2002, suspended sand- and silt-sized sediment made up 85 percent of the inflow sediment mass. It made up 83 percent of the inflow mass in 2003, and 92 percent during the storm events between December 1, 2005, and February 1, 2006. In contrast, most of the sediment that exited the reservoir downstream was suspended clay. That clay-sized sediment made up 91 percent of the outflow mass of sediment in 2002, 93 percent of the outflow sediment mass in 2003, and 84 percent of the outflow sediment mass for the 2005-06 storms. Table 5 summarizes the masses of suspended sediment in the inflows and outflow, as well as the reservoir trap efficiencies, for each of the three modeled time periods.

\section{Sources of Sediment to the Reservoir Outflow}

The calibrated model was used to examine the relative contribution of each of Detroit Lake's tributaries to the suspended sediment in the reservoir outflow for 2003. Each suspended sand and silt and suspended clay group for each inflow, including the distributed tributaries (the small ungaged tributary groups), was modeled as a separate sediment group for this analysis. The settling rates for each group were the same as those in the calibrated model, so that the sediment behavior overall was unchanged. The only difference was the ability to track various sources of sediment through the system. In order to determine the initial distribution of sediment from various sediment sources in the reservoir to start the year, an entire year's simulation was run with estimated initial conditions; then the distribution of sediment from various sources in the reservoir on the last day of the year was used to reinitialize the sediment distribution at the start of the year, before running the simulation a final time.

The results from this scenario show that all inflows to Detroit Lake contributed to the suspended sediment in the reservoir outflow (fig. 23, table 6). The contributions were generally greatest from the North Santiam and Breitenbush Rivers, the largest tributaries, throughout the year. The contribution from the North Santiam River was unique in that it contributed suspended sediment to the outflow from September through November, whereas the other tributaries had ceased to deliver much sediment in that period. The North Santiam River is the only Detroit Lake tributary sourced in a glacial basin, and the reasons for the different characteristics of sediment in the headwaters of this river are still under investigation by the USGS.

Model results indicated that sediment that exited the reservoir in 2003 was mostly suspended clay (93 percent of the total mass). The largest contribution of this clay-sized sediment came from the North Santiam River, followed by Breitenbush River, Blowout Creek, the distributed

Table 6. Fate of suspended sand and silt, and suspended clay from the major tributaries to Detroit Lake, Oregon, 2003.

[The small tributary group refers to the ungaged or distributed tributaries. Correction refers to the difference between initial and final (initial-final) suspended sediment mass in the lake water column. 1 metric ton $=1,000$ kilograms]

\begin{tabular}{|c|c|c|c|c|c|c|}
\hline Tributary & $\begin{array}{c}\text { Inflow } \\
\text { (metric tons) }\end{array}$ & $\begin{array}{c}\text { Outflow } \\
\text { (metric tons) }\end{array}$ & $\begin{array}{c}\text { Correction } \\
\text { (metric tons) }\end{array}$ & $\begin{array}{c}\text { Deposited } \\
\text { (metric tons) }\end{array}$ & $\begin{array}{l}\text { Percent } \\
\text { trapped }\end{array}$ & $\begin{array}{l}\text { Percent } \\
\text { exported }\end{array}$ \\
\hline \multicolumn{7}{|c|}{ Suspended silt and clay } \\
\hline Box Canyon Creek & 812 & 7 & 0 & 805 & 99 & 1 \\
\hline French Creek & 349 & 1 & 0 & 348 & 100 & 0 \\
\hline Kinney Creek & 1,040 & 33 & 0 & 1,007 & 97 & 3 \\
\hline Small tributary group & 1,673 & 71 & 0 & 1,602 & 96 & 4 \\
\hline Blowout Creek & 1,982 & 33 & 0 & 1,949 & 98 & 2 \\
\hline Breitenbush River & 6,953 & 17 & 0 & 6,936 & 100 & 0 \\
\hline North Santiam River & 7,560 & 3 & 0 & 7,557 & 100 & 0 \\
\hline \multicolumn{7}{|c|}{ Suspended clay } \\
\hline Box Canyon Creek & 120 & 70 & 11 & 61 & 47 & 53 \\
\hline French Creek & 175 & 86 & 7 & 96 & 53 & 47 \\
\hline Kinney Creek & 154 & 123 & 4 & 35 & 22 & 78 \\
\hline Small tributary group & 380 & 229 & -14 & 137 & 37 & 63 \\
\hline Blowout Creek & 427 & 255 & 15 & 187 & 42 & 58 \\
\hline Breitenbush River & 1,073 & 541 & 57 & 589 & 52 & 48 \\
\hline North Santiam River & 1,849 & 886 & 84 & 1,047 & 54 & 46 \\
\hline
\end{tabular}




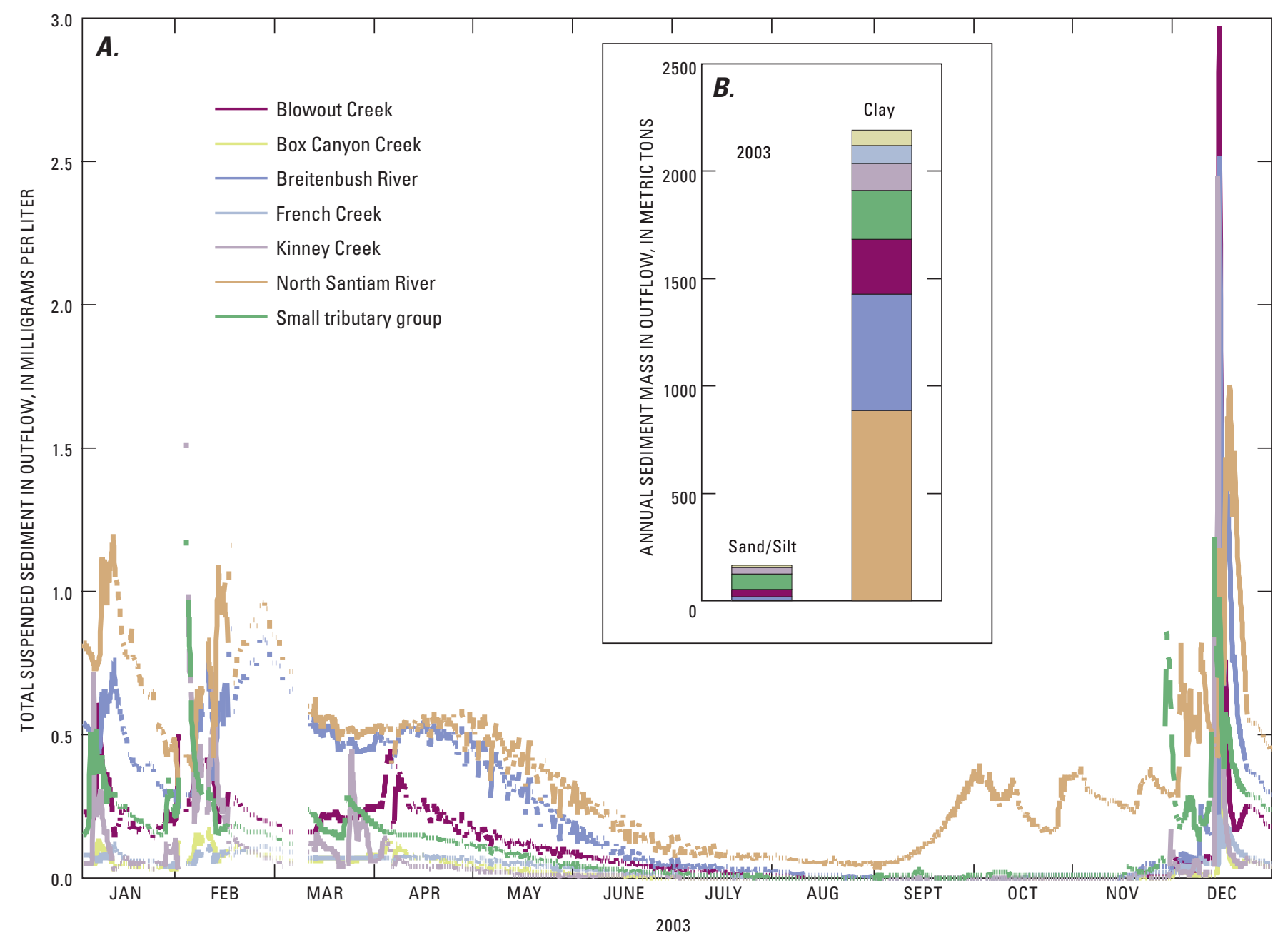

Figure 23. Modeled sources of total sediment in reservoir outflow of Detroit Lake during $2003(A)$, and annual modeled sum of sediment mass in the Detroit Lake outflow in 2003, showing the difference between the suspended sand and silt and suspended clay sediment groups, and showing the modeled sources $(B)$ of the sediment in each group. These values also are presented in table 6 . A metric ton is equal to $1,000 \mathrm{~kg}$ or 2,205 pounds.

tributaries (small ungaged tributaries), Kinney, French, and Box Canyon Creeks. The minor amount of suspended sand and silt discharged from the reservoir came predominantly from Kinney Creek, Blowout Creek, and the ungaged small tributaries. Tributaries that enter farther upstream contributed less suspended sand and silt compared to those that enter closer to the dam, probably because the suspended sand and silt settles more rapidly. Table 6 quantifies each tributary's export efficiency for both suspended sand and silt and suspended clay. The North Santiam River, entering about $8 \mathrm{~km}$ upstream, contributed no suspended sand and silt to the reservoir outflow. The distributed tributaries represent an estimate of sediment associated with the ungaged fraction of inflow to the reservoir. The model apportions the distributed tributaries' inflows with their associated sediment to every segment in the model, including those segments closest to the dam. In the model, sediment introduced into the reservoir near the dam does not have much time to settle before it reaches the dam outflow. This is the reason that the distributed tributary represents a relatively large portion of suspended sediment in the reservoir outflow. Some small ungaged inflows do enter Detroit Lake near the dam (fig. 1), and they are likely to contribute disproportionately to the coarse sediment load in the reservoir outflow.

\section{Effect of Dam on Release Water Temperature}

The water temperature in the North Santiam River at the location of the dam, without the influence of the reservoir, was estimated by calculating a volume-weighted mix of Detroit Lake model inflows for 2003 (fig. 24). This is only an estimate, as it does not include warming or cooling that 
might occur between each gage location and the dam. For the 2003 inflow mix, maximum water temperatures occurred in July, whereas the modeled reservoir outflow reached annual maximum temperatures later in the year, in early October. The presence of the reservoir, with its midlevel lake outlet, produced cooler temperatures in summer and warmer temperatures in autumn compared to the river in the absence of the reservoir. This effect has been observed for many other storage reservoirs in which the outflow draws water from relatively deep in the water column (for instance Hagg Lake,
Sullivan and Rounds, 2006). Besides differences in seasonal temperature patterns, the reservoir outflow also had smaller 24-hour temperature variations compared to the inflow-mix. In addition to the fact that the reservoir outflow can exceed Oregon's maximum water temperature criterion in autumn, the cool summer temperatures of the outflow also may be undesirable (Larson, 2000). In an attempt to address this issue, the USACE experimented with mixing the cool waters released from Detroit Dam's power-generating outlet with warmer surface waters released from the spillway in

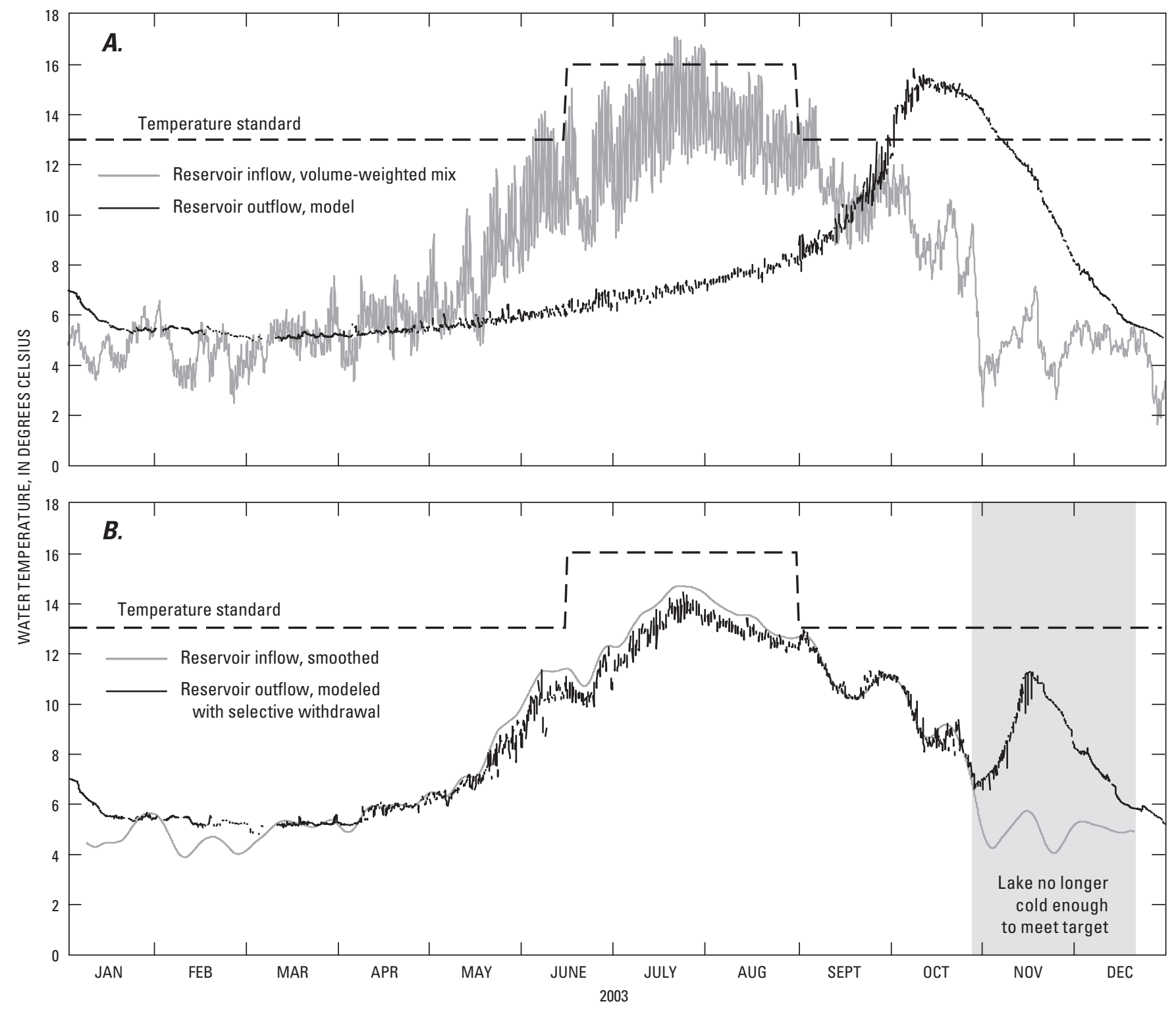

Figure 24. (A) Maximum water temperature standard for the North Santiam River, Oregon, downstream of Big Cliff and Detroit Dams, an estimate of the water temperatures in the absence of the dams calculated using a volume-weighted mix of reservoir inflows for 2003, and modeled water temperatures of the water released from Detroit Dam and $(B)$ smoothed water temperature of the volume-weighted mix of the reservoir inflows, used as a temperature target for the selective withdrawal simulation, along with the modeled reservoir release temperatures for that scenario. The selective withdrawal scenario was able to achieve the temperature target for much of the year, but the lake did not have enough cool water to meet that target in early spring or late autumn. The modeled release temperature did, however, remain less than the temperature standard for the entire year. 
June and July of 1979. Further study by USACE led to the recommendation that a selective withdrawal tower be installed as part of Detroit Dam (Larson, 2000 referring to two USACE reports). This type of device would blend water from different levels in the water column in order to release water with a more natural seasonal temperature pattern. The USACE recently completed a selective withdrawal tower at Cougar Reservoir, another large storage reservoir in the Willamette Basin, to address downstream temperature issues (Resource Management Associates, 2003).

The calibrated Detroit Lake model was used to assess the degree to which a more natural seasonal temperature pattern could be achieved downstream of the dam by using such a device. The hypothetical selective withdrawal device was set up to withdraw water from the penstocks at their current elevation, and from a sliding gate outlet that could be adjusted once per day vertically through the water column to select an elevation, with a corresponding water temperature, that could be blended into the penstocks to meet a temperature target. The elevation of the sliding-gate outlet was determined automatically by the model in an attempt to match a userspecified downstream temperature target. In this run, the model was given a downstream temperature target based on the inflow-mix water temperature and "filtered" twice with a 7-day running average (fig. 24B). These running averages were used simply to smooth the target temperature time series and remove daily variations and some effects of short-term weather variations. The resulting outflow water temperature from this simulation is shown in figure $24 B$ along with the temperature target. The selective withdrawal device allowed the reservoir outflow to approximate a more-natural seasonal temperature pattern for most of the year. However, the reservoir did not have a sufficient stored volume of cold water in autumn to meet the target, leading to a small temperature peak at that time of year. The peak was small, and was less than the water temperature criterion. A comparison to the reservoir in 2003 without selective withdrawal (fig. 25A), shows that selective withdrawal (fig. $25 B$ ) led to a shallower thermocline, as warm water was withdrawn from near the lake surface in summer. Further work may examine the effect of such an altered thermal structure of the lake on the transport and fate of suspended sediment in the lake. Additional scenarios also could be run to simulate different outlet characteristics, various temperature targets, altered flows, changes in reservoir operation, and/or climate shifts.

\section{Summary and Future Work}

A CE-QUAL-W2 model of Detroit Lake was constructed and calibrated for calendar years 2002 and 2003, and for a period of heightened storm inflows between December 1 , 2005, and February 1, 2006. The model effectively simulated

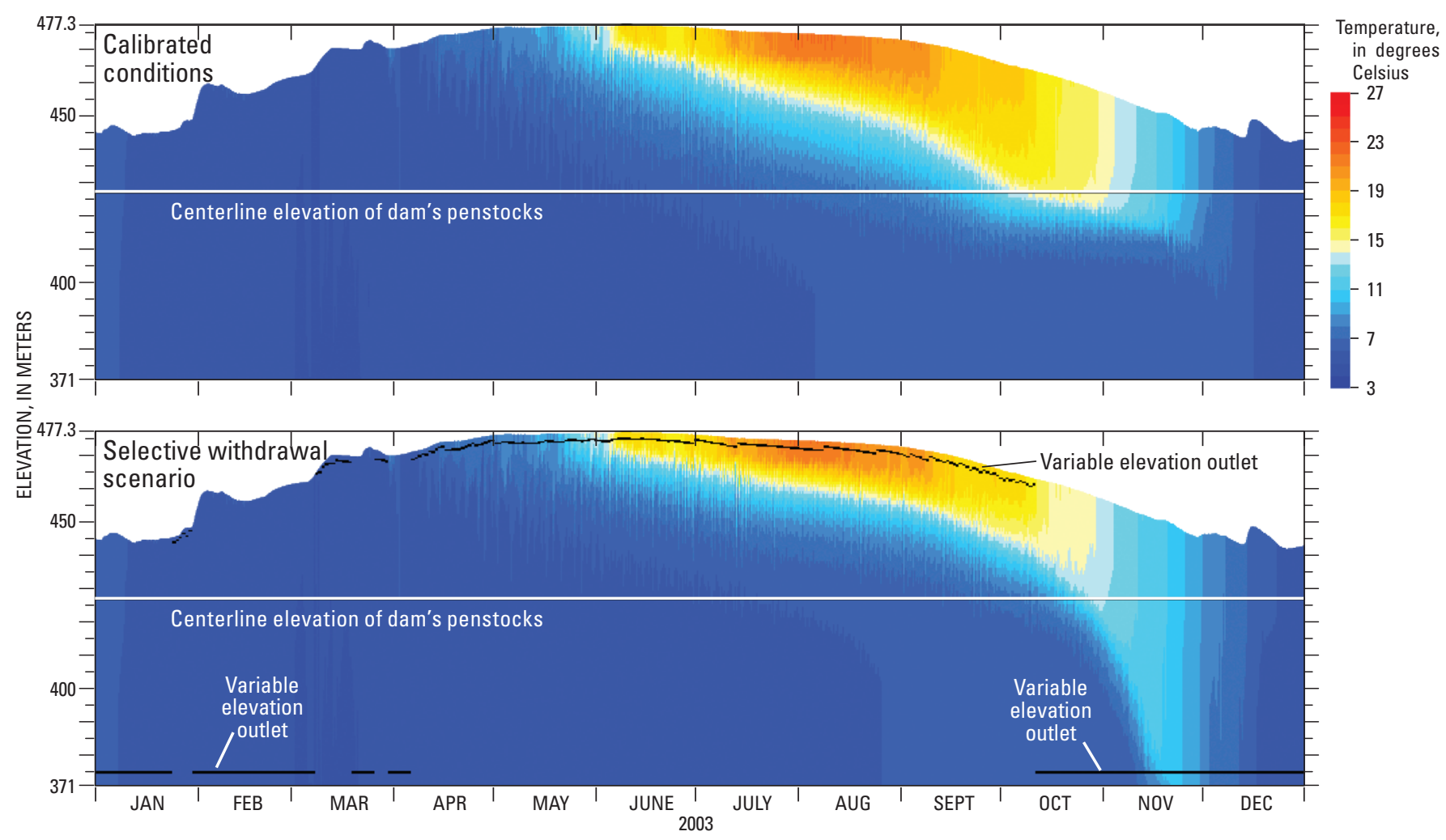

Figure 25. Modeled water temperature profiles in Detroit Lake, Oregon, near the dam as a function of time during 2003 for calibrated conditions, and the selective withdrawal scenario. 
the lake's spatial and temporal patterns in hydrodynamics, water temperature, TDS, and two size groups of suspended sediment. Most sediment entered the reservoir during storm events. The lake is an efficient sediment trap, capturing more than 90 percent of the incoming suspended sediment in each of the modeled time periods. The model results indicate that a large percentage of suspended sand and silt was deposited in the upper reaches of the reservoir; this size of sediment typically only exited the reservoir in the outflow during large storm events. In contrast, clay-sized sediment stayed in suspension for longer periods of time, and composed most of the suspended sediment in the reservoir outflow. The source of the suspended sediment in the outflow came from all tributaries to Detroit Lake, but the largest contributions were from the two largest tributaries, the North Santiam and Breitenbush Rivers. A larger percentage of the suspended sand and silt in the outflow came from tributaries closer to the dam, because this size of suspended sediment settles rapidly.

Water temperature in Detroit Lake followed a seasonal pattern, with surface warming in spring, development of a thermocline in summer, and surface cooling and turnover in autumn. At present, the temperature of water released from Detroit Lake is cooler in summer and warmer in autumn compared to a more natural seasonal temperature pattern. Simulation of a hypothetical selective withdrawal device showed that with structural and operational adjustments, the outflow from Detroit Lake could approximate a more natural seasonal temperature pattern for most of the year, but also that the lake's supply of cold water might be exhausted in autumn.

Modeling the spatial patterns of sediment deposition in the reservoir could be improved by including algorithms to simulate sediment scour and resuspension. This would allow a more detailed examination of the spatial patterns of sedimentation in the reaches near the major inflows that are affected by seasonal drawdown. The current Detroit Lake model also does not distinguish between inorganic and organic sediment. It would be useful to collect more data to determine the makeup of the inflow suspended material, as CE-QUAL-W2 is able to simulate degradation of particulate organic material. Simulation of the 2005-06 storms showed the importance of large storm events on sediment transport into and out of the reservoir, and the model could be used to further assess future or historic storm inflows and suspended sediment transport and fate. For example, the large 1996 flood event would be a good candidate for further use and testing of the model. The model also could be used to assess patterns of sediment deposition in the lake over long time periods.

The use of a selective withdrawal device could be modeled in more detail, examining how different combinations of outlets, various downstream temperature targets, changes in reservoir operation, and modified release schedules might affect downstream water temperatures. An existing North Santiam River CE-QUAL-W2 flow and water temperature model could be upgraded and connected to the Detroit Lake model in order to predict how these changes to Detroit Lake might affect water temperatures on the North Santiam and Santiam Rivers downstream to the confluence with the Willamette River. Extension of the Detroit Lake model to include the Big Cliff reregulating reservoir would be a logical component of that effort.

The Detroit Lake model could be expanded to include nutrients and algae dynamics. Blue-green algae blooms are a potential concern because of their associated toxins and their known occurrence in Detroit Lake, albeit at low levels. Significant blooms have occurred in other Cascade Range reservoirs, leading to health advisories and recommendations that visitors avoid contact with lake water. In order to simulate algae in the Detroit Lake model, additional data on nutrients, chlorophyll, and algae would be needed.

\section{Acknowledgments}

This study was made possible with cooperative funding from the City of Salem and the USGS. Mark Uhrich (USGS) has led the larger effort over a number of years to study and monitor sediment in the North Santiam Basin; this project has produced much of the suspended sediment data and turbiditysuspended sediment regressions used to construct the Detroit Lake model. Amy Brooks, David Piatt, Anna Buckley, and Adam Stonewall (all USGS) helped with field work related to this project. Arthur Armour and Jim Britton (USACE) provided information on dam operation, and the USACE provided funding for the Agrimet weather station near Detroit Lake. Helpful reviews of the manuscript were provided by Mark Uhrich (USGS), Christopher Konrad (USGS), Robert Annear (Portland State University), and Sophia Hobet (City of Salem).

\section{Supplemental Material}

A Web site has been created to distribute supplemental material from this project. Visitors to http://or.water.usgs. gov/santiam/detroit lake/ can:

- Download this report;

- Obtain the calibrated Detroit Lake models, including model source code, data files, and model executables;

- Download or view animations of model output;

- Obtain algae and nutrient data collected during the investigation;

- Download GIS coverages of the lake's bathymetry, with fly-by visualizations; and

- Follow links to related material and data. 


\section{References Cited}

Ambers, R.K.R., 2001, Using the sediment record in a western Oregon flood-control reservoir to assess the influence of storm history and logging on sediment yield: Journal of Hydrology, v. 244, p. 181-200.

Anderson, C.W., 2005, Turbidity (Version 2.1): U.S. Geological Survey Techniques of Water-Resources Investigations, book 9, chap. A6, section 6.7, accessed December 19, 2006, at http://pubs.water.usgs.gov/twri9A6/.

Bragg, H.M., and Uhrich, M.A., 2004, The North Santiam River, Oregon, water-quality monitoring network: U.S. Geological Survey Fact Sheet FS-2004-3069, 6 p.

Brune, C.B., 1953, Trap efficiency of reservoirs: Transactions of the American Geophysical Union, v. 34, no. 3, p. 407418 .

Cole, T.M., and Wells, S.A., 2002, CE-QUAL-W2: A twodimensional, laterally averaged, hydrodynamic and waterquality model, version 3.1: U.S. Army Corps of Engineers, Instruction Report EL-02-1 [variously paged].

E\&S Environmental Chemistry, Inc. and North Santiam Watershed Council, 2002, North Santiam River watershed assessment: June, 2002, accessed August 24, 2006, at http:// www.esenvironmental.com/north santiam download.htm.

Hem, J.D., 1985, Study and interpretation of the chemical characteristics of natural water. Third Edition: U.S. Geological Survey Water-Supply Paper 2254, 263 p.

Horne, A.J., and Goldman, C.R., 1994, Limnology, Second Edition: McGraw-Hill, Inc., New York, 576 p.

Larson, D.W., 2000, Willamette Reservoirs Oregon. Detroit, Big Cliff, Green Peter, Foster, Blue River, Cougar. Limnological and water-quality studies, 1950-2000. Final Report: U.S. Army Corps of Engineers, 1402 p.

Lide, D.R., ed., 2006, CRC handbook of chemistry and physics (87 ${ }^{\text {th }}$ edition): Taylor and Francis, Boca Raton, FL [variously paged].

Oregon Climate Service, 2006, Oregon Weather Summary, January 2006, accessed September 24, 2006, at http://www. ocs.orst.edu/page links/periodicals/2006/Jan06.html.

Oregon Department of Environmental Quality, 2003, Oregon Administrative Rules—“The Three Basin Rule": OAR 340041-0350, accessed September 29, 2006, at http://arcweb. sos.state.or.us/rules/OARs 300/OAR 340/340 041.html.
Oregon Department of Environmental Quality, 2006, Oregon's 2004/2006 Integrated Report, accessed March 13, 2007, at http://www.deq.state.or.us/wq/assessment/rpt0406.htm.

Resource Management Associates, Inc., 2003, Blue River temperature modeling with HEC-5Q. Final Report: Prepared for U.S. Army Corps of Engineers, September.

Snyder, N.P., Rubin, D.M., Alpers, C.N., Childs, J.R., Curtis, J.A., Flint, L.E., and Wright, S.A., 2004, Estimating accumulation rates and physical properties of sediment behind a dam: Englebright Lake, Yuba River, northern California: Water Resources Research, v. 40, W11301.

Sullivan, A.B., and Rounds, S.A., 2004, Modeling streamflow and water temperature in the North Santiam and Santiam Rivers, Oregon: U.S. Geological Survey Scientific Investigations Report 2004-5001, 35 p. Available online at http://pubs.water.usgs.gov/sir20045001/.

Sullivan, A.B., and Rounds, S.A., 2006, Modeling water quality effects of structural and operational changes to Scoggins Dam and Henry Hagg Lake, Oregon: U.S. Geological Survey Scientific Investigations Report 20065060, 36 p. Available online at http://pubs.water.usgs. gov/sir20065060/,

Sullivan, A.B., Rounds, S.A., Uhrich, M.A., and Bragg, H.M., 2006, Modeling suspended sediment and water temperature in Detroit Lake, Oregon: Proceedings of the Joint Federal Interagency Conference, $8^{\text {th }}$ FISC and $3^{\text {rd }}$ FIHMC, Reno, NV.

Taylor, G.H., 2002, The climate of Oregon, zone 4, Northern Cascades, Oregon Climate Service: Special Report 914, accessed September 29, 2006, at http://www.ocs.orst.edu/ pub ftp/reports/zone/zone4.html.

Uhrich, M.A., and Bragg, H.M., 2003, Monitoring instream turbidity to estimate continuous suspended-sediment loads and yields and clay-water volumes in the upper North Santiam River basin, Oregon, 1998-2000: U.S. Geological Survey Water-Resources Investigations Report 03-4098, $43 \mathrm{p}$.

U.S. Army Corps of Engineers (1953) Water control manual for Detroit and Big Cliff Lakes, Oregon: Portland District Report, December 18, 1953.

Vanoni, V.A., ed., 1975, Sedimentation Engineering: American Society of Civil Engineers, New York, 745 p. 
Manuscript approved for publication, January 14, 2007

Prepared by the USGS Publishing Network,

Publishing Service Center, Tacoma, Washington

Donita Parker

Sharon Wahlstrom

Bobbie Jo Richey

For more information concerning the research in this report, contact the Oregon Water Science Center Director

U.S. Geological Survey

10615 S.E. Cherry Blossom Dr.

Portland, OR 97216

http://or.water.usgs.gov 


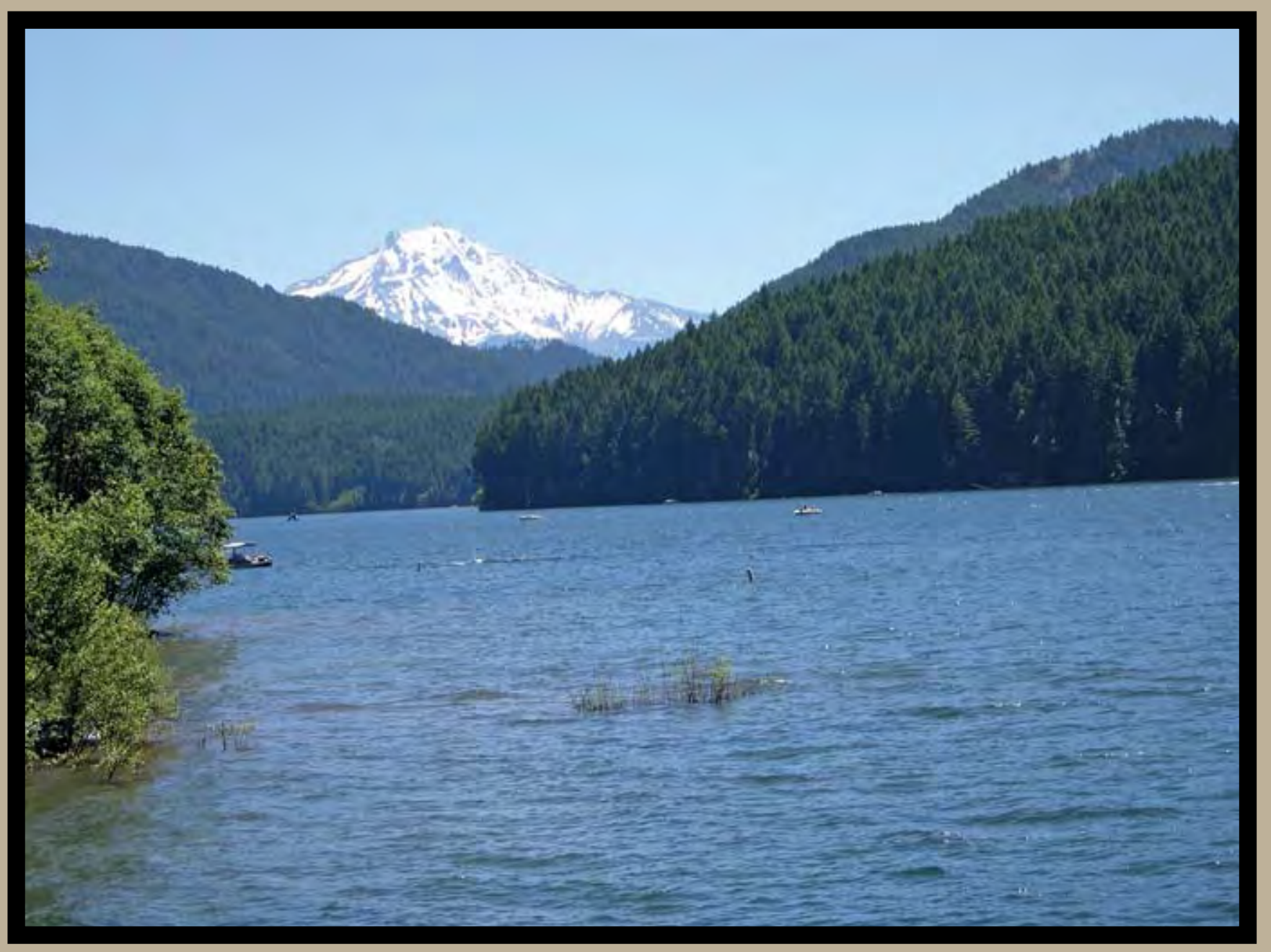

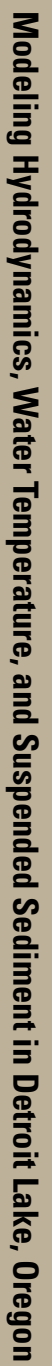

